\title{
ANÁLISE ESTRUTURAL DO TURISMO DO MUNICÍPIO DE ILHÉUS (BA)
}

\section{CRISTIANE APARECIDA DE CERQUEIRA}

Dissertação apresentada à Escola
Superior de Agricultura "Luiz de Queiroz",
Universidade de São Paulo, para
obtenção do título de Mestre em Ciências,
Área de Concentração: Economia
Aplicada.

PIR A C I C A B A

Estado de São Paulo - Brasil

Agosto - 2002 


\section{ANÁLISE ESTRUTURAL DO TURISMO DO MUNICÍPIO DE ILHÉUS (BA)}

\section{CRISTIANE APARECIDA DE CERQUEIRA}

Bacharel em Ciências Econômicas

Orientador: Prof. Dr. FERNANDO CURI PERES

Dissertação apresentada à Escola
Superior de Agricultura "Luiz de Queiroz",
Universidade de São Paulo, para
obtenção do título de Mestre em Ciências,
Área de Concentração: Economia
Aplicada.

PIRA CICA B A

Estado de São Paulo - Brasil

Agosto - 2002 
Dados Internacionais de Catalogação na Publicação (CIP)
DIVISÃO DE BIBLIOTECA E DOCUMENTAÇÃO - ESALO/USP

\author{
Cerqueira, Cristiane Aparecida de \\ Análise estrutural do turismo do município de llhéus (BA) / Cristiane \\ Aparecida de Cerqueira. - - Piracicaba, 2002. \\ $167 \mathrm{p}$. \\ Dissertação (mestrado) - - Escola Superior de Agricultura Luiz de Queiroz, \\ 2002. \\ Bibliografia. \\ 1. Análise estrutural 2. Capital (economia) 3. Econometria 4. Economia \\ do turismo 3. Indústria turística I. Título
}

CDD 338.4791

\title{
"Permitida a cópia total ou parcial deste documento, desde que citada a fonte - $\mathrm{O}$ autor"
}


A minha mãe Raimunda Sales de Almeida e a minha tia Terezinha Sales (Rosinha), a vocês devo tudo que sou. 


\section{AGRADECIMENTOS}

À Deus, pela graça constantemente derramada sobre a minha vida.

À coordenação do Curso de Pós-Graduação em Economia Aplicada (Esalq - USP), pela oportunidade de realizar o curso.

Ao Dr. Fernando Curi Peres pela orientação e convivência. O conhecimento transmitido, sua amizade, seu apoio ... foram componentes essenciais ao meu crescimento profissional.

A professora Ana Kassouf que, como primeira orientadora, demonstrou tranquilidade na direção dos meus primeiros passos durante o curso.

Ao professor Rodolfo Roffmann, pela competência, profissionalismo e disposição. Meu profundo respeito e agradecimento.

Ao professor Guilhotto pela confiança e atenção dispensada.

Aos professores Evaristo e Alexandre pelas contribuições a este trabalho.

Aos demais professores do departamento de Economia, Administração e Sociologia, pelos ensinamento transmitidos.

Aos funcionários do departamento Helena, Maielli, Pedro, Marcia, Elenice, Ligiana, Álvaro, Luciane, Cristiane. Obrigada pela disposição, paciência e carinho.

À Universidade Estadual de Santa Cruz (UESC) e Departamento de Ciências Econômicas (DCEC) pelo apoio e concessão de bolsa de estudo.

Aos professores Aurélio Macedo, Joaquim Bastos e Hélio Barroco, por sempre acreditarem e investirem em mim. Devo muito deste trabalho a vocês. 
À minha amiga Moema Midlej, suas contribuições, sua praticidade, seu carinho, seu ombro amigo ... é um socorro presente e um bálsamo.

À administração do Aeroporto, meios de hospedagem e demais estabelecimentos comerciais e/ou turísticos de llhéus por permitirem a realização da pesquisa junto aos turistas presentes no município.

Às estagiárias Luiza Carla e Juliana pela coleta de dados e informações referentes a este trabalho.

À Joseane pela colaboração na elaboração desta dissertação.

Aos amigos Valeriana, Patrícia, Raquel, Casimiro, Carla Freire, Jaenes, Cândida, Clailton, Espedito, Cleia, Cleise, Ana Regina, Raquel, Nívea, Glorinha, João e Cris. Foi e é muito bom ter vocês como companheiros.

Especialmente à minha amiga Cinthia Cabral Costa. Sua vida é uma benção para mim.

A todos que direta e indiretamente contribuíram para a execução deste trabalho. 


\section{SUMÁRIO}

Página

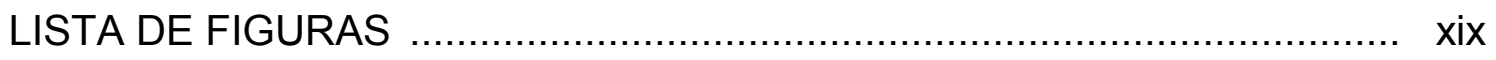

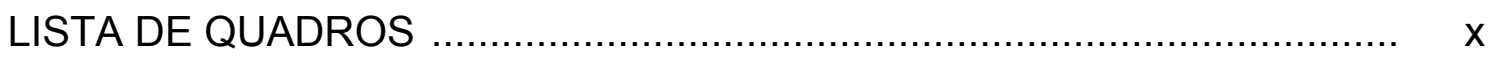

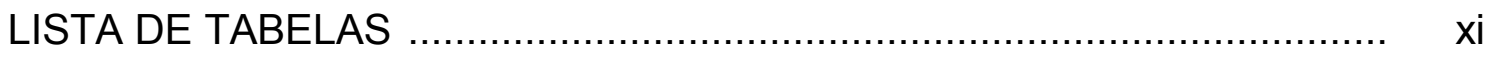

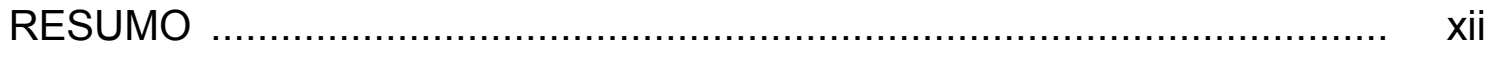

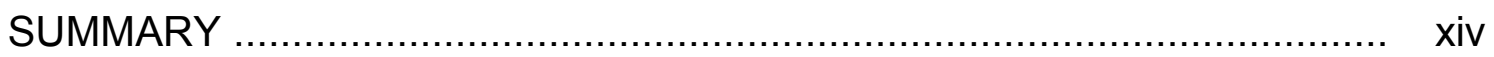

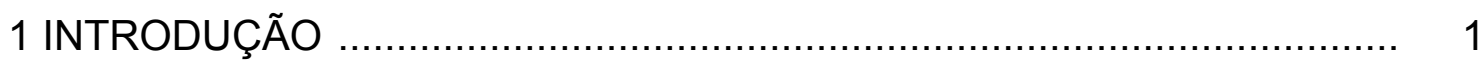

1.1 Sul da Bahia: desempenho da cacauicultura e da atividade turística do município de llhéus ...................................................... 1

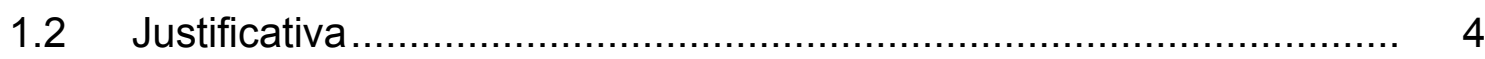

1.2.1 Importância da atividade turística para a economia mundial.............. 4

1.2.2 Importância da atividade turística para a economia brasileira.............. 6

1.2.3 Turismo do nordeste brasileiro e a problemática da indústria turística de llhéus ........................................................................... 8

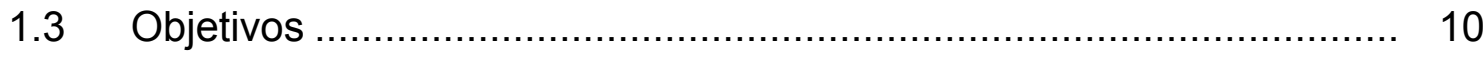

2 REVISÃO DE LITERATURA …........................................... 11

2.1 Fundamentos para a análise estrutural da atividade turística ............ 11

2.2 Importância dos fatores de produção e/ou estoques de capitais na economia 
2.2.1 Breve revisão teórica: do mercantilismo ao keynesianismo

2.2.2 Concepções recentes sobre o papel dos estoques de capitais na atividade econômica

2.2.3 Concepções sobre o papel do capital social na economia 31

2.2.4 Concepções sobre o papel do capital natural na economia 44

2.3 Revisão de alguns estudos empíricos relevantes 63

2.3.1 Análise da estrutura da industria turística: estudo de casos 63

2.3.1.1 De trabalhos realizados em outros países 63

2.3.1.2 De trabalhos realizados no Brasil 72

3 METODOLOGIA 81

3.1 Área estudada, indicadores e fonte de dados 81

3.2 Análise fatorial. 87

3.2.1 Considerações sobre o modelo de análise fatorial. 87

3.2.2 Estatísticas associadas à análise fatorial ................................... 92

3.3 Análise de regressão …...................................................... 94

3.3.1 O modelo econométrico ............................................................. 94 
$4 \quad$ RESULTADOS E DISCUSSÃO ................................................... 99

4.1 Notas sobre a pesquisa e tratamento dos indicadores referentes à estrutura turística de llhéus ................................. 99

4.2 Análise descritiva sobre a estrutura turística de Ilhéus .................... 101

4.3 Características do turistas entrevistados e informações

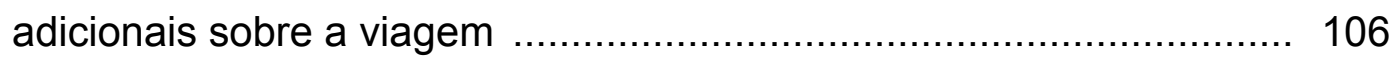

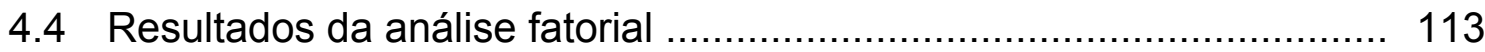

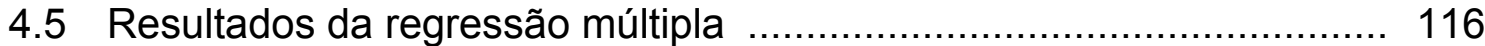

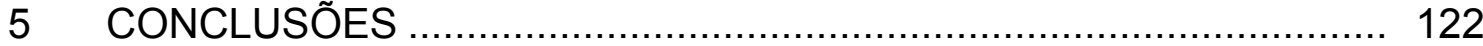

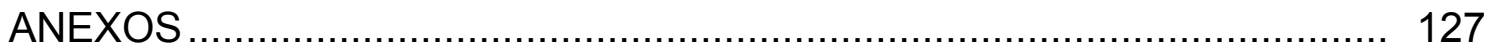

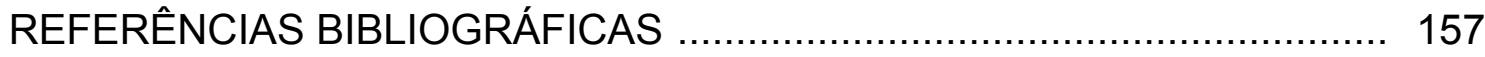




\section{LISTA DE FIGURAS}

Página

1 Estado civil do turista do município de llhéus (BA) ............................. 107

2 Faixa etária (em anos) do turista do município de llhéus (BA) .............. 108

3 Nível de instrução do turista do município de llhéus (BA) ...................... 109

4 Meios de transportes utilizados pelo turista em seu deslocamento até o município de llhéus (BA) ..................................................... 110

5 Fatores que influenciaram a vinda do turista ao município de

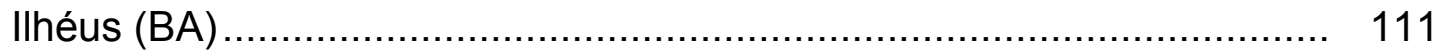

6 Fatores que motivaram a vinda do turista para o município de Ilhéus (BA) 


\section{LISTAS DE QUADROS}

Página

1 Definições de capital social selecionadas e classificadas de acordo com as fontes, as ações coletivas praticáveis e seus resultados 


\section{LISTA DE TABELAS}

Página

1 Indicadores dos estoques de capitais (físico, financeiro, humano, social e natural) referentes à estrutura turística.................................... 86

2 Estatísticas descritivas das notas registradas (entre 0 e 10) para as variáveis referentes à estrutura turística do município de Ihéus (BA)

3 Matriz rotacionada: cargas fatoriais e comunalidades dos 30 indicadores (variáveis) relacionadas à estrutura turística do município de llhéus (BA) ................................................................ 114

4 Indicadores da estrutura turística e suas respectivas cargas fatoriais: relação dos estoques de capitais do município de llhéus (BA)

5 Coeficientes, valores de "t" e estatística "F" do modelo de regressão linear 


\title{
ANÁLISE ESTRUTURAL DA ATIVIDADE TURÍSTICA DO MUNICÍPIO DE ILHÉUS (BA)
}

\author{
Autora: CRISTIANE APARECIDA DE CERQUEIRA \\ Orientador: Prof. Dr. FERNANDO CURI PERES
}

\section{RESUMO}

Neste trabalho, analisou-se o turismo (no período de baixa estação) do município de Ilhéus, Estado da Bahia. A avaliação da estrutura turística local foi realizada através de indicadores referentes às concepções de estoques de capital (físico, financeiro, humano, social e natural), das características do turista e de sua viagem, por meio da análise fatorial e análise de regressão. Os resultados dão informações importantes relacionadas aos produtos e serviços turísticos. Em média, a avaliação geral, ou satisfação total do turista foi considerada satisfatória. O item mais criticado foi "manifestações populares". As "amenidades ambientais" revelaram ser o atributo mais desejado e bem avaliado pelos visitantes. Das características dos turistas, foi possível traçar um perfil da demanda. Com relação ao estado de origem do visitante, observou-se uma distribuição equivalente procedente de unidades territoriais não litorâneas e próximas a llhéus. Os dados revelaram inter-relações entre alguns indicadores: a maioria dos visitantes é composta de indivíduos casados e adultos; grande parte possuí nível superior e renda 
relativamente alta. Das características da viagem dos turistas, é importante ressaltar algumas informações: do total dos visitantes, poucos foram influenciados pelas agências de viagem (8\%) e propaganda e publicidade $(4 \%)$, meios tradicionais de venda ou distribuição do produto e serviços turísticos. No que diz respeito ao motivo da viagem, $81 \%$ dos abordados afirmaram que vieram a llhéus a passeio/lazer, mas os indicadores referentes ao entretenimento/diversões foram os mais criticados. Outros resultados das análises econométricas acrescentam informações importantes. A análise fatorial resumiu 35 indicadores da estrutura turística de llhéus em 7 fatores. Os coeficientes do modelo de regressão linear, referentes aos fatores extraídos, revelaram que, quanto mais qualificada a estrutura turística, melhor a avaliação geral do visitante. O "fator 2 - Capital humano associado aos serviços de entretenimento" foi o de maior importância (peso) na nota geral. Os outros 6 fatores também contribuíram, significativamente, para a explicação da nota geral (ou avaliação geral) dada pelo turista aos produtos e serviços oferecidos. As análises revelam que, na baixa estação, o turismo local teve avaliação não muito boa. Portanto, a análise da estrutura turística de llhéus indica que a atividade necessita de maior investimento nos estoques de capitais, capazes de manter a procura e o crescimento do setor. 


\title{
STRUCTURAL ANALYSIS OF TOURISM IN THE COUNTY OF ILHEUS, BAHIA STATE, BRAZIL
}

\author{
Author: CRISTIANE APARECIDA DE CERQUEIRA \\ Adviser: Prof. Dr. FERNANDO CURI PERES
}

\section{SUMMARY}

The study presents an analysis of the tourism industry in the county of Ilheus, Bahia State, Brazil. Local tourism structure was evaluated by using the concepts of capital stocks of the basic production factors (physical, financial, human, social, and natural) and by describing some personal characteristics of the tourists and some specification of the trip. Factorial and regression analyses were the utilized analytical tools. Tourist satisfaction was found to be reasonable in the overall evaluation of the sampled individuals. Among the attractions demanded by the tourist the most reproved item was 'popular manifestations'. The attribute 'environmental charm' was considered most desirable and scored best in the visitors' evaluation. Based on the characteristics of the tourists, a demand profile could be drawn. The visitors' states of origin were distributed equally between inland territories and regions near llheus. Inter-relations were observed among some studied variables: the majority of visitors are adult and married and most of them have a university degree and a relatively high income. The characteristics of tourist trips revealed 
that among all visitors, few had been influenced by travel agencies ( $8 \%)$ and by advertisement and publicity (4\%), the traditional means of selling tourist products and services. In most cases, tourists had come to llheus looking for fun and leisure, while the research showed that the most criticized items were precisely entertainment/amusement. Factorial analysis combined 35 items evaluated by the tourists into 7 factors. The coefficient of the linear regression model showed that the higher the qualification of the touristic structures, the better the overall evaluation of the tourists. Factor 2, called "human capital linked to entertainment services," was found to be most important (higher weight) in the overall score. The other six factors also contributed significantly to the explanation of the overall score (or overall evaluation) given by the tourists. It can be said that tourist structures in Ilheus need higher investments to increase capital stocks in order to maintain demand and growth of its tourist business. 


\section{INTRODUÇÃO}

\subsection{Sul da Bahia: desempenho da cacauicultura e da atividade turística do município de llhéus}

A atividade cacaueira, durante longo período, constituiu a base do crescimento econômico do Sul da Bahia. As lavouras de cacau implantadas desde o final do século XIX garantiram à região a condição de maior centro da produção nacional. Atividade indutora de emprego e renda, já manteve cerca de 2,2 milhões de pessoas; isto a caracteriza como de uso intensivo de mãode-obra (Mascarenhas, 1996).

Nas últimas décadas, a atividade cacauicultora vem experimentando diversas crises. O aumento dos preços do cacau na década de 70 e o consequente crescimento da produção em países como Costa do Marfim, Malásia, Indonésia e Brasil trouxeram instabilidade às cotações internacionais nos anos posteriores. Midlej (1997) destaca que nos fins dos anos 70 o produto foi cotado a US\$3.632,00/ton, mas no início dos anos 90 os preços já tinham se reduzido a até US $\$ 912,35 /$ ton. Assim, o aumento da produção mundial sem contrapartida do crescimento da demanda resultou na acumulação dos estoques e na queda dos preços mundiais. Essa conjuntura trouxe certa descrença na atividade, redução do uso de insumos e da produtividade das lavouras e consequente perda da participação nacional na produção global.

Afora a tendência de redução dos preços, a partir de 1989, a atividade passou a enfrentar outro grave problema: a vassoura de bruxa, 
doença que ataca os cacauais, apodrecendo seus frutos. De acordo com Mascarenhas (1996) no Sul da Bahia mais de 90\% das lavouras foram atingidas, reduzindo ainda mais a produção, a rentabilidade dos produtores e a liquidez da economia local, estimando-se que em meados dos anos 90 havia 120 mil trabalhadores desempregados. Dessa forma, concomitante à redução dos preços, produtividade e exportação de cacau, observou-se elevado nível de desemprego e redução da renda na economia regional.

O município de Ilhéus, localizado na Microrregião Ilhéus-Itabuna (Sul da Bahia) ${ }^{1}$, constituiu um dos maiores produtores de cacau do país. No ano de 1993, Ilhéus possuía a maior produção de cacau local, com 51.683 ha de área colhida, 25.841 ton. produzidas, cujo valor alcançou $R \$ 845.705,00$. Nesse ano, o segundo maior produtor, Ibirapitanga, registrara apenas 25.000 ha de área colhida, 11.737 ton. produzidas e $\mathrm{R} \$ 384.185,00$ de valor da produção, estatísticas sensivelmente menores que as de Ilhéus (Gasparetto 1998b). Segundo Queiroz (1993a, p.33): "... a consolidação e apogeu da cacauicultura no período compreendido entre 1890 e 1930 levara o Brasil à posição de segundo produtor de cacau do mundo. A Bahia, primeiro produtor do Brasil e Ilhéus, primeiro produtor da Bahia".

Pode-se dizer que, a economia ilheense sempre esteve atrelada ao desempenho da lavoura cacaueira. Desde o limiar do crescimento desta atividade, através de suas demandas, o município passa a equipar-se para atender às necessidades regionais. Ampliam-se as estradas, equipamentos urbanos, transações via porto e as conexões aéreas. "Ilhéus, com suas facilidades portuárias e localização estratégica na periferia da maior área produtora de cacau da região, desde cedo irá concentrar as funções comerciais, industriais e de serviços da zona cacaueira", descreveu Queiroz (1993a, p.34). Assim, durante o apogeu da referida lavoura, os níveis de

\footnotetext{
${ }^{1}$ Bahia (2000).
} 
atividade, emprego e renda local se sustentavam. A partir do final da década de 80, a economia ilheense passa a registrar contrações que alcançam a década de 90, consequências das crises experimentadas pela cacauicultura no período. Nessa conjuntura, vislumbra-se a diversificação de explorações e propõe-se alternativas ${ }^{2}$ de atividades econômicas como possíveis fontes para desenvolvimento regional e municipal.

Dentre outras atividades econômicas sugeridas para a região, o turismo aparece como alternativa para llhéus. O município reúne alguns atributos necessários ao desenvolvimento de uma eficiente indústria turística por possuir recursos históricos, culturais e naturais de elevada importância. Cenário de lutas e conquistas, "berço" da formação do Estado da Bahia e da civilização cacaueira, a fundação da capitania de São Jorge dos Ilhéus, no ano de 1536, coincide com a colonização brasileira, refletindo muito da história e cultura nacionais. Ocupado primeiramente pelos portugueses, o conjunto arquitetônico é composto por igrejas, casas e logradouros em estilo Barroco Colonial ou Neogótico. Ademais, possui $90 \mathrm{~km}$ de belas praias numa vasta área de Mata Atlântica.

Nos últimos anos o turismo ilheense vem se destacando em nível regional. O município apresentou a terceira receita turística estadual, num montante de $\mathrm{R} \$ 43,5$ milhões. Na Microrregião Ilhéus-Itabuna, o maior parque hoteleiro encontra-se em Ilhéus, com 116 hotéis, 1.803 quartos e 4.860 leitos. Os outros municípios litorâneos, a exemplo de Canavieiras (com 31 hotéis, 326 quartos, 768 leitos) e Itacaré (com 22 hotéis, 140 quartos, 369 leitos), mesmo bastante demandados, ficam muito aquém da capacidade de atendimento com relacão a llhéus (Empresa, 2000b).

\footnotetext{
${ }^{2}$ Mascarenhas (1996) utilizou informações da Comissão Executiva do Plano da Lavoura Cacaueira (CEPLAC), órgão federal, que através do Programa de Diversificação Agronômica das Regiões Produtoras de Cacau (Prodacau), apresenta as alternativas de atividade econômica propostas para os municípios do Sul da Bahia.
} 


\subsection{Justificativa}

O turismo tem gerado grandes benefícios às economias, resultado do contínuo aumento do fluxo de visitantes ao longo dos anos e em várias partes do globo. Os dados revelam a capacidade que esta atividade possui na geração de renda e emprego, através da ampliação de divisas, faturamento, impostos e etc. Esses benefícios não só alcançam os setores diretamente ligados ao turismo, mas também aqueles indiretamente relacionados. Porém, em algumas áreas a atividade é organizada e explorada de forma amadora, daí a importância de análises minuciosas que redirecione o planejamento e desenvolvimento da indústria turística de forma que satisfaça seus consumidores e favoreça a comunidade local.

\subsubsection{Importância da atividade turística para a economia mundial}

As estatísticas, resultados das pesquisas realizadas em diversas nações, corroboram o importante papel do turismo nas economias. Em todo o mundo, no ano de 1999, registrou-se 4.656,9 milhões de chegadas de turistas, US $\$ 455,5$ bilhões em divisas, US $\$ 4,5$ trilhões de faturamentos, US $\$ 792,4$ bilhões de impostos e 192 milhões de empregos nesta atividade específica (Empresa, 2000a).

Métodos e modelos cientificamente fundamentados são utilizados quando se objetiva avaliar o impacto direto e indireto produzidos pela indústria turística nas economias locais. Nesse sentido, os multiplicadores de renda e emprego são os indicadores mais difundidos nas análises sobre a importância do turismo em determinadas áreas ${ }^{3}$. Witt \& Moutinho (1989), para o ano de

\footnotetext{
3 Segundo Lages \& Milone (2001) os multiplicadores específicos do turismo permitem quantificar as variações dos níveis de renda, do emprego, do produto em decorrência das variações verificadas nos níveis iniciais de gastos com o turismo. Maiores detalhes sobre multiplicadores ver :

MILLER, R.E.; BLAIR, P.D. Input-output analysis: foudations and extensions. New Jersey: Prentice Hall, 1995. 463p.
} 
1989, apresentam as estimativas do multiplicador de renda do turismo da Turquia $(1,98)$, Grã-Bretanha $(1,73)$, Jamaica $(1,27)$ e Irlanda do Norte $(1,10)$, dentre outras.

Gastos dos visitantes com hospedagem e compras e investimentos do setor público e/ou privado também são exemplos dos fatores considerados nos estudos dos multiplicadores. Ablas (1991) exemplifica o caso de ilha de Anglesey, na Inglaterra, apresentando os resultados encontrados para os multiplicadores dos gastos dos turistas, que são as seguintes: hotéis e casas de hóspedes $(1,25)$, casas de aluguel $(1,14)$, quartos em casas de famílias $(1,58)$, camping $(1,35)$ e o multiplicador geral $(1,25)$. No entanto, observou-se que esta ilha, de pequena dimensão, recebe do continente parte do suprimento de serviços, o que reduz significativamente os impactos da atividade turística e do efeito multiplicador na área.

Por certo, o sucesso da atividade turística depende de vários fatores, ou seja, o desempenho do turismo é determinado pela satisfação dos próprios turistas, viabilidade econômica das atividades prestadoras de serviços e ofertantes de bens e pelos impactos nos níveis de emprego e renda para a comunidade, dentre outros aspectos, ou seja, a satisfação do turista cria condições para ampliar e assegurar o fluxo turístico e os gastos no local, elevando a rentabilidade dos negócios ligados ao setor e o nível de vida da população local.

Em certos casos, no entanto, o turismo como ferramenta para o desenvolvimento local apresenta limitações. Tooman (1997) estudando a relação turismo e desenvolvimento nos Estados do Tennessee e Carolina do Norte, nos Estados Unidos, concluiu que as perspectivas globais dos impactos aparentemente são boas, mas para a população residente esses ganhos são questionáveis. Ele ressalta que a atividade precisa ser manejada de forma que amplie seus benefícios, gerando renda e emprego sem deterioração de outros 
indicadores determinantes do bem-estar das pessoas. Assim, no planejamento e ações devem ser observados os custo sociais, culturais e ambientais incorridos da exploração turística.

\subsubsection{Importância da atividade turística para a economia brasileira}

No âmbito nacional, as estatísticas igualmente justificam a essencialidade da indústria turística para a economia. O Brasil, em 1998, registrou 38,2 milhões de turistas domésticos, US $\$ 13,2$ bilhões de receitas diretas com o turismo interno e US\$31,9 bilhões de renda indireta. Em 1999, 5,1 milhões de turistas estrangeiros visitaram o país, gerando US $\$ 3,9$ bilhões em ingressos de divisas (Empresa 2000a).

Os modelos e estimativas macroeconômicas da contribuição do turismo, como a matriz de insumo-produto da economia turística brasileira, também constatam a importância dessa atividade. O turismo chega a impactar 52 setores da economia nacional e entre 1994 e 1998 contabilizou 5 milhões de postos de trabalho e US\$7 bilhões em arrecadação (Carvalho, 2000a). Para 1988, o efeito multiplicador da renda foi igual a 1,75. Do total de rendimento obtido, $36,1 \%$ é dirigido aos salários, $57,3 \%$ para os lucros em geral e $6,6 \%$ para os impostos e subsídios (Coelho, 1991). Esses percentuais além de indicar a importância do turismo na geração de renda, comprovam os níveis elevados de concentração quando da distribuição da renda turística.

O turismo é uma arma poderosa para alcançar o desenvolvimento econômico, principalmente quando comparado a outros setores da economia. A atividade turística pode acionar novos processos de produção e amenizar as desigualdades regionais e sociais porque "... tem a peculiaridade de gerar vagas em áreas com desemprego estrutural, como centros de cidade e áreas rurais" (Carvalho 2000a, p.1). Da pauta de exportações brasileira, em volume de divisas, o setor turístico só perde para a soja. Entre 1997 e 1998, a receita turística cresceu $41 \%, 28$ pontos percentuais acima do crescimento da receita 
de minério de ferro e 30 pontos acima do valor gerado com a exportação de açúcar.

"... cada US $\$ 7$ mil deixados no país repercute na manutenção de um emprego. Enquanto na indústria automobilística são necessários $\mathrm{R} \$ 170$ mil para gerar um emprego, no turismo apenas $\mathrm{R} \$ 40$ mil possibilitam um emprego direto num hotel; $\mathrm{R} \$ 10$ mil empregam uma pessoa num restaurante e $\mathrm{R} \$ 50$ podem garantir matéria-prima e emprego a um artesão" (Carvalho 2000c, p.2 ).

Em períodos recessivos em que a questão do emprego e renda merecem maior atenção, o setor turístico deve ser priorizado nas políticas governamentais. Isto se deve ao fato de ser este setor um dos mais intensivos em mão-de-obra e, portanto amortecedor com relação a desutilização do fator trabalho. Segundo Torres (1991) ampliando a relação média trabalho/produção (coeficiente de absorção) pode-se também ampliar o nível de emprego. Nesse sentido, $85 \%$ das atividades que se encontram no setor terciário e que compõe a indústria turística apresentam coeficiente de absorção que supera em quase $50 \%$ a média nacional.
"admitindo-se que a queda na produção seja de tal forma a preservar o setor turismo, pode-se calcular que haverá uma redução do nível esperado de desemprego em aproximadamente $8 \%$, isto é, de cada 100 (cem) desempregados que seriam gerados, somente $92 \%$ se confirmariam" (Torres 1991, p.17). 


\subsubsection{Turismo do nordeste brasileiro e a problemática da indústria turística de llhéus}

Com relação ao Estado do Ceará, foram estimados os impactos dos gastos dos turistas e do governo sobre o produto, renda e emprego. Através do modelo insumo-produto, constatou-se que a primeira categoria de gastos, o dos visitantes, revelou-se mais significativa. O impacto total dos gastos dos turistas na produção foi de $R \$ 1.354 .836,00$ e na renda gerada na economia do Ceará, de $\mathrm{R} \$ 839.672,00$, quando 76 unidades a mais de emprego foram registrados (Teixeira, 1998).

As estatísticas da Bahia apresentam informações surpreendentes. Em nível estadual, para cada emprego direto na hotelaria são criados cinco empregos indiretos, e estima-se que já tenha sido gerado 100 mil postos de trabalho até meados da década de 90 . Porto Seguro, no ano de 1995, registrou receita turística de $\mathrm{R} \$ 187$ milhões, ampliando seus efeitos sobre diversas atividades afins e sobre as cidades próximas, através da obtenção de alguns serviços e produtos (Burman \& Queiroz, 1996).

Mesmo sendo um dos locais mais requisitados no Brasil, o crescimento da indústria turística de Porto Seguro ainda não assegurou uma boa qualidade de vida à maioria dos seus habitantes. O município possui reduzida renda per capta anual de $\mathrm{R} \$ 2.460,00$ e considerável concentração da renda, onde $42,5 \%$ dos chefes das famílias recebem menos que um salário mínimo e 12,8\% não obtêm rendimentos. Na verdade, este município diversificou a economia ao expandir os níveis de investimentos turísticos, mas não promoveu distribuição da riqueza (Burman \& Queiroz, 1996).

As características sócio-econômicas e a realidade da População Economicamente Ativa (PEA) do município de llhéus remetem à necessidade do planejamento estratégico e do desenvolvimento sustentável da indústria turística, de forma que esta contribua efetivamente para a ampliar os níveis de 
produto, emprego e renda da comunidade. A desigualdade social ilheense sempre esteve entre as mais "gritantes" do Brasil. Na região, o município ocupou, em 1994, o $4^{0}$ lugar no ranking do Índice de Desenvolvimento Econômico. Por outro lado, posicionou-se no $48^{0}$ no ranking de Desenvolvimento Social. Registrou $34 \%$ de taxa de analfabetismo e $63,7 \%$ do abastecimento de água inadequado. Em 1991, o município possuía $57,61 \%$ dos chefes de famílias recebendo até 1 (um) salário mínimo e 3,5\% do total não obteve rendimento (Gasparetto, 1998b).

Como alternativa de atividade indutora de emprego e renda, observa-se que a indústria turística de llhéus não se encontra eficientemente desenvolvida e apresenta algumas fragilidades. Se usufruísse de todo o seu potencial, em termos de atrativos históricos, culturais e naturais llhéus poderia tornar-se um dos mais importantes municípios turísticos brasileiro. Nesse sentido, o planejamento estratégico que englobasse em suas diretrizes a infraestrutura, qualificação da mão-de-obra local, preservação do patrimônio natural e histórico/cultural, propagandas, dentre outros aspectos estruturais da atividade, promoveria competitividade, minimizando o efeito da sazonalidade do setor. Só assim o turismo ilheense se beneficiaria das contínuas transformações econômicas, políticas e sociais que determinam taxas crescentes dos fluxos turísticos mundiais, compostos por visitantes cada vez mais exigentes.

Em resumo, todos os fatores mencionados na análise justificam a necessidade de estudos sistemáticos que possibilitem o conhecimento minucioso da estrutura da indústria turística, identificando-se os pontos de entrave que impedem o aumento da demanda pelo "produto Ilhéus"; estudos que redirecionem os planos e ações públicas e privadas visando à melhor exploração dos recursos e do turismo ilheense, ampliando, assim, os níveis de atividade e renda e a qualidade de vida dos nativos, promovendo o desenvolvimento municipal. 


\subsection{Objetivos}

\section{Objetivo geral}

Analisar a estrutura da indústria turística do município de llhéus, através da avaliação dos estoques de capitais.

Objetivos específicos

- Avaliar os estoques de capital físico, financeiro, humano, social e natural relacionados à atividade turística do município de Ilhéus;

- Estimar a importância (o peso) de cada estoque de capital (físico, financeiro, humano, social e natural) na avaliação geral da atividade turística de llhéus. 


\section{REVISÃO DE LITERATURA}

\subsection{Fundamentos para a análise estrutural da atividade turística}

Muito tem se discutido sobre o turismo. Esta atividade tem sido foco de estudos dos mais diversos ramos das ciências. Por sua abrangência e complexidade, torna-se de interesse multidisciplinar. Desse modo, no intuito de tratar dos diversos aspectos interligados ao setor é que Beni (1998), na obra intitulada "Análise Estrutural do Turismo", desenvolve um modelo referencial denominado "Sistema de Turismo" (SISTUR). Considerando o conjunto das relações, organização e ações peculiares à atividade, o SISTUR permitem conhecer a estrutura global da indústria turística, tornando-se um modelopadrão para profissionais que atuam na área.

Segundo Beni (1998), um sistema é definido como:

“... um conjunto de partes que interagem de modo a atingir um determinado fim, de acordo com um plano ou princípio; o conjunto de procedimentos, doutrinas, idéias ou princípios, logicamente ordenados e coesos com intenção de descrever, explicar ou dirigir o funcionamento de um todo" (Beni 1998, p.25).

Dentro da linguagem da teoria de sistema, o turismo é apresentado num esquema sintetizador dinâmico, relacionando uma série de funções inerentes à natureza da atividade. Para tanto, o SISTUR é subdividido em três conjuntos (e seus respectivos subsistemas): o conjunto das "Relações 
Ambientais" (subsistema ecológico, econômico, social e cultural), da "Organização Estrutural" (subsistema da superestrutura e da infra-estrutura) e das "Ações Operacionais" (subsistema do mercado, da oferta, de produção, de distribuição, da demanda e de consumo). A divisão do sistema em componentes é para proporcionar ao analista as informações necessárias e verificar a operacionalização do mesmo. Com relação ao SISTUR, esta divisão dá-se em virtude das inúmeras inter-relações verificadas em cada um dos conjuntos de subsistemas, que também interagem entre si no sistema total.

O primeiro conjunto, o das "Relações Ambientais" do SISTUR, descreve como se dá a realização de trocas da atividade turística com todo o meio circundante, relação que é interdependente e não auto-suficiente. O "subsistema ecológico" refere-se à capacidade de suporte dos ecossistemas naturais. Por certo, possibilidades de crescimento do SISTUR estão em função das disponibilidades quantitativa e qualitativa dos recursos naturais, já que a atividade turística, na maioria das vezes, requer a exploração daqueles bens. Beni (1998) ressalta que "... cuidar do econômico não implica necessariamente proteger o ecológico; na entanto, cuidar deste significa beneficiar aquele a médios e longos prazos" (Beni 1998, p.51). O "subsistema ecológico" abrange os seguintes fatores: espaços turísticos natural e urbano e seu planejamento territorial; atrativos turísticos e conseqüências do turismo sobre o meio ambiente, uso do solo, preservação da flora, fauna, recursos hídricos, do litoral, das paisagens etc.

O "subsistema econômico" engloba a organização dos processos produtivos, a distribuição e o intercâmbio dos meios materiais. O turismo visto como atividade econômica compreende uma série de bens e serviços colocados no mercado que são oferecidos aos viajantes. Assim, move-se na esfera do econômico e é condicionado pela conjuntura econômica tanto na ordem micro quanto na macro, quando os custos de produção, a renda, os 
índices de preços e demais fatores influenciam as decisões dos empresários do setor e dos turistas. O turismo está submetido a todas as leis econômicas que atuam nos demais ramos e, através do seu efeito multiplicador, provoca repercussões em outros setores da economia. Pode-se, ainda, descrever variáveis adicionais pertencentes a este subsistema: tráfego de turistas, balanço turístico, uso da capacidade instalada, pessoal empregado no setor, contribuição do turismo no balanço de pagamentos e no Produto Interno Bruto (PIB), participação na entrada de divisas, efeito multiplicador de receita, emprego etc.

Dentro do "subsistema social", a mobilidade social, os aspectos psicossociais e os modelos sociológicos associados ao turismo é que são abordados. Sabe-se que a mobilidade humana amplia os vínculos comunitários, independente do domicílio habitual, amplia os horizontes culturais dos indivíduos, modifica o comportamento e traz novo dinamismo à sociedade. No entanto, obviamente, todo fenômeno sociológico envolve elementos favoráveis e desfavoráveis. O turismo é um produto dessa mobilidade assessorado pela modernização dos meios de transportes e comunicação. Do ponto de vista do viajante, o turismo representa o somatório de condutas particulares num grande conjunto; desta forma, do ponto de vista individual, particular do turista, a psicologia, a sociologia, ou melhor, a psicologia social se mostrará útil para a compreensão das motivações de viagens, da estrutura de gastos, permanência, freqüência de visitas etc. A preparação de mão-de-obra da população residente para absorção no mercado e o nível de relacionamento social entre a população residente e os visitantes são mais dois dos vários aspectos relacionados ao "subsistema social". Além disso, a economia do turismo depende do seu modelo sociológico. O desenvolvimento turístico pode estar vinculado ao capitalismo popular de empreendedores nativos e originar-se de iniciativas individuais até atingir grande parcela da comunidade, sob bases solidárias e de cooperação popular. A atividade pode ser planejada por grandes capitais ou, 
ainda, ser caracterizada pelo afluxo de capital externo associado às iniciativas da população local.

O "subsistema cultural" recorda que o espaço cultural é o resultado da intervenção do trabalho físico e mental do homem no espaço natural. Os recursos turísticos culturais são, pois, os produtos diretos das manifestações culturais, entendidas como o conjunto de crenças, valores e técnicas para lidar com o meio ambiente, compartilhado entre os contemporâneos e transmitido de geração a geração. Os bens culturais (patrimônio cultural) dispostos ao consumo turístico compreendem: monumentos históricos, registros que expressam os valores da sociedade, museus e galerias de arte que reúnem modalidades de expressão artística (arquivo das etapas do desenvolvimento de culturas), manifestações populares de caráter religioso e profano, folclore (reconstituição cênica de ambiência histórica e de etnias), e cultura popular (caracterizadora de regiões). Artesanato, instalações e equipamentos para animação cultural como as facilidades ecológicas (parques naturais, reservas, zoológicos), as facilidades esportivas (pistas de esqui, bicicleta e patinação, postos de pesca), as facilidades de diversão (cassinos, salões de jogos e de dança, bares), facilidades culturais (museus, teatros, centros culturais), facilidades diversas (playgrounds, locais para piquenique) igualmente fazem parte do "subsistema cultural".

O segundo conjunto, da "Organização Estrutural" do SISTUR é subdividido no "subsistema da superestrutura e da infra-estrutura". O "subsistema da superestrutura" refere-se à complexa organização tanto pública quanto privada que harmoniza a produção e a venda de diferentes produtos e serviços do SISTUR. Compreende a política oficial de turismo e sua organização jurídica-administrativa que se manifesta no conjunto de medidas de organização e promoção dos órgãos e instituições oficiais e estratégias governamentais que interferem no setor. Por exemplo, pode-se atuar através das políticas de proteção ao patrimônio natural, de investimento, de 
ordenamento da oferta, de promoção e divulgação dos valores culturais, de incentivo ao turismo receptivo e interno etc.

O "subsistema de infra-estrutura" é classificado em infra-estrutura geral e específica. A infra-estrutura geral é aquela cujo investimento serve a todos os setores da economia e ao setor turístico por incidente. É o conjunto de obras e instalações da estrutura física de base. Consiste na rede viária, de transportes, de telecomunicações, de segurança, de distribuição de energia e água, captação de esgotos, iluminação e limpeza pública e outros. Enfim, engloba todos os serviços urbanos indispensáveis à qualidade de vida e a todo empreendimento habitacional ou empresarial que venha a ser implantado.

A infra-estrutura específica abrange os investimentos ocorridos em áreas de concentração turística. Engloba todo tipo de vias de acesso, energia e iluminação pública, pavimentação das ruas em locais essencialmente turísticos. Como exemplo, pode-se citar a extensão dos melhoramentos a novos distritos e loteamentos ou ampliações da infra-estrutura existente, como novos aeroportos, rodovias etc. Também, abrange os serviços de preservação e conservação do patrimônio natural e cultural (obras realizadas nos parques municipais e regionais e para proteção das encostas do litoral, preservando a paisagem integrada à configuração da orla marítima). Sistema informativo e indicativo das áreas, locais, logradouros e instalações turístico-culturais e recreativas, instalação de equipamentos não-convencionais de acesso (teleféricos de acesso a regiões montanhosas, rampas para saltos com asa-delta, acesso às praias e embocaduras de rios). Local para camping, equipamentos de conforto junto aos espaços culturais e de recreação (sanitários públicos, bebedouros, balneários com vestiários e outros), todos são elementos constituintes da infraestrutura turística específica. Segundo Beni (1998), "Os indicadores da situação são: a existência ou não desses equipamentos e serviços; o percentual da população flutuante - consumidores do turismo que os utilizam; o nível de 
atendimento e o grau de satisfação dos turistas em relação a eles" (Beni 1998, p.130).

O terceiro conjunto, o das "Ações Operacionais" do SISTUR, é composto pelo subsistema do mercado, da oferta, de produção, de distribuição, da demanda e de consumo. O "subsistema do mercado" parte do conceito de mercado como constituído por um sistema de informações que permite a milhares de agentes econômicos, produtores e consumidores tomarem decisões. A idéia é de troca de produtos ou valores - o comércio; as pessoas e empresas oferecem e demandam bens, serviços e capitais e determinam o surgimento organizado e as condições dessa troca. É um sistema muito sensível às mudanças nas condições dos diferentes elementos que o interagem, onde o mecanismo fundamental são os preços. Para cada produto turístico, pode-se identificar um tipo de mercado, real ou potencial. Porém, em sua maioria, os mercados de turismo inserem-se na categoria "concorrência imperfeita", onde os produtos são diferenciados. As empresas de turismo têm uma certa capacidade de variar seus preços: os clientes estarão dispostos a pagar mais por um produto melhor, ou a consumir mais de uma empresa que ofereça preços mais atraentes. Porém, esta capacidade (poder de mercado) é de alcance reduzido, limitado pela concorrência. De acordo com Beni (1998):

"No mercado altamente competitivo do turismo, o fator 'qualidade' é o único critério que se impõe de maneira natural para determinar o êxito ou o malogro dos produtos e serviços. A qualidade deve ser portanto a estratégia usada em seu lançamento e aplicada para garantir sua permanência competitiva no mercado. A qualidade refere-se ao serviço aliado ao produto que, tal como a oferta, é intangível, embora mensurável... Assim com a qualidade se manifestando simultaneamente ao serviço, a produtividade relativa só poderá ser expressa em termos de satisfação real dos 
consumidores. É essa satisfação que imprimirá a imagem símbolo do produto 'serviços turísticos' no mercado, também conhecida pela taxa de fidelidade... O verdadeiro desafio comercial está na realização do tripé qualidade/preço/capacitação profissional..." (Beni 1998, p.151152).

O "subsistema de oferta" constata que fenômeno turismo é, em seu sentido mais amplo, um setor produtivo, mas não no sentido habitual do termo como se figura nos demais setores da economia. O turismo por natureza é resultante de várias atividades econômicas. O produto turístico total, em sentido macroeconômico, é constituído de um conjunto de subprodutos, como transporte, hotelaria, restaurante etc. Em sentido microeconômico, cada um desses subprodutos pode receber a denominação "produto turístico". Este subsistema é subdividido em duas categorias, a "oferta turística original" e a "oferta turística derivada", ambas igualmente necessárias ao desenvolvimento do referido setor. A "oferta turística original" é constituída de inúmeros elementos tangíveis e intangíveis e não de um só produto bem determinado; sem a qual não se poderia realizar nenhum processo produtivo. Esta categoria é composta pelos recursos turísticos primários, como os elementos hídricos (neve, gelo, águas minerais e termais), e a flora (florestas, bosques, matas e toda superfície natural). Também, inclui os valores criados pela atividade do homem, tanto antigos como modernos (história, religião, cerimônia, tradições, folclore, cultura, monumentos históricos etc.). Segundo Beni (1998),

"É assim que o clima, o deserto, a praia, o museu, os costumes tornam-se bens diretamente produtivos através de um processo de transformação que os introduz no circuito econômico... Os elementos turísticos primários de um país são 'bens livres' e, mais particularmente, no que concerne ao patrimônio turístico, são presentes que provém quer da 
natureza, quer dos antepassados. Se são considerados oferta econômica ou bens econômicos, é apenas porque os turistas estão dispostos a sacrificar tempo e dinheiro para chegar até eles" (Beni 1998, p.156).

A "oferta turística derivada" é composta pelos transportes, diversas formas de alojamento, alimentação, lazer/recreação/entretenimento (estabelecimentos noturnos, por exemplo), pelos organizadores e agências de viagens, bancos. Corresponde aos serviços produzidos, os quais, em conjunto com a oferta original, dão consistência ao consumo e compõe os elementos que integram a oferta no seu sentido amplo, numa estrutura de mercado.

O "subsistema de produção" são as unidades produtivas de bens e serviços turísticos que combinam adequadamente os fatores de produção de forma a otimizar a função de produção e determinar o volume da oferta. Os insumos básicos dessa produção denominam-se recursos e atrativos turísticos, mas o processo de produção se desenvolve de maneira eficiente quando dispõe da infra-estrutura de apoio, como transporte e comunicações, saneamento básico e ambiental e serviços públicos. O conceito de oferta em turismo tem conotação mais ampla que a simples produção de bens e serviços, pois abrange várias instalações e equipamentos. Assim, o produto turístico é um conjunto composto por bens e serviços produzidos em diversas unidades econômicas, que sofrem agregação no mercado ao serem postos em destaque os atrativos turísticos. As unidades de produto turístico, diferentemente de outros bens, têm caráter temporal e devem ser consumidas no momento em que se produzem. Portanto, o produto turístico tem as seguintes características gerais: baseia-se no fator tempo; é irrecuperável quando não utilizado por não ser acumulado; não pode ser transportado nem transferido; e é dinâmico e instável, por depender dos gostos, preferências etc. 
O "sistema de distribuição" envolve o conjunto de medidas tomadas com o objetivo de levar o produto ou serviço do produtor ao consumidor. Este refere-se, em geral, à escolha dos canais de distribuição; seleção da oferta e dos intermediários, a programação de visitas; prospecção e entrega da oferta aos intermediários, a estimulação e controle de vendas; etc. A distribuição pode ser feita de três maneiras: venda direta ao consumidor; venda via intermediários, como as operadoras turísticas, as agências de turismo, a empresa hoteleira e empresa de transporte e "marketing"; e, ou, venda simultânea, direta e através de intermediários.

O "subsistema de demanda" é uma compulsória de bens e serviços, e não demanda simples de elementos ou de serviços específicos adquiridos isoladamente, ou seja, nesta atividade são demandados bens e serviços que se complementam. Os principais fatores que afetam a demanda turística são de ordem sócio-econômica (sexo, idade, país, renda, educação, tamanho da família, estado civil, posição social do turista, motivo da viagem e outros), psicológica, específicos de cada região e os que ligam países emissores a receptores.

O "subsistema de consumo" se atenta à necessidade premente de melhor conhecer os consumidores e sua decisão de compra, como alvo e centro desse setor de serviços. Idade, renda, educação e outras informações demográficas fornecem uma visão dos consumidores de determinados bens e serviços, mas, geralmente, não explicam o motivo do turista eleger um determinado destino ou operadora turística, por exemplo. Aqui, os fatores psicológicos como a percepção, aprendizado e personalidade, dentre outros, também são considerados influenciadores da decisão da compra.

Por certo, a exposição resumida até aqui apresenta-se limitada para dissecar todos os componentes amplamente detalhados por Beni no "Sistema de Turismo". Todavia, o conteúdo descrito permite observar que as variáveis, os 
indicadores, os índices e outros dados citados e relacionados possibilitam avaliar quantitativa e qualitativamente as funções primárias e derivadas da atividade turística. "O método referencial de estruturação do SISTUR permite definir, isolar e identificar seus reguladores, para a tarefa maior da pesquisa em turismo..." (Beni 1998, p.233). Para tanto o objetivo geral do SISTUR é:

"Organizar um plano de estudos da atividade do turismo, levando em consideração a necessidade, ..., de fundamentar as hipóteses do trabalho, justificar posturas e princípios científicos, aperfeiçoar e padronizar conceitos e definições, e consolidar condutas de investigação para instrumentar análises e ampliar a pesquisa, com a consequente descoberta e desenvolvimento de novas áreas de conhecimento em turismo" (Beni 1998, p.44).

Esse trabalho não pretendeu aplicar o modelo SISTUR, mas observar o conjunto de variáveis, aqui destacadas, que permitem avaliar empiricamente a atividade turística e fundamenta-la nos pressupostos da ciência econômica, ou seja, a pretensão de analisar a estrutura do turismo igualmente exige atentar aos aspectos e concepções abordados pelos renomados economistas. Por isso, as seções posteriores discorrerão sobre o vínculo entre os fatores produtivos e, ou, estoques de capitais e o desempenho econômico. Num horizonte temporal serão identificados os elementos, variáveis, indicadores e relações que evidenciam as razões do desenvolvimento/subdesenvolvimento econômico. Por certo, a lógica empregada em análises agregadas são também verificadas quando se considera o desempenho de setores específicos de atividade. Assim, para a análise da estrutura da industria turística do município de llhéus, o presente trabalho considerou algumas das variáveis do SISTUR associando-as à concepção do capital físico, financeiro, humano, social e natural, no intuito de 
compreender como cada um desses estoques tem influenciado o nível do turismo ilheense.

\subsection{Importância dos fatores de produção e, ou, estoques de capitais na economia}

Não são recentes as análises sobre o papel dos fatores de produção e, ou, estoques de capitais na economia. Por isso, nesta seção apresenta-se, inicialmente, uma síntese das principais doutrinas e fundamentos teóricos de representação de algumas escolas de pensamento econômico. Em seguida, far-se uma exposição das concepções contemporâneas sobre estoques de capital físico, financeiro e humano. Por fim, serão delineadas as discussões atuais sobre a importância do capital social e capital natural na economia.

\subsubsection{Breve revisão teórica: do mercantilismo ao keynesianismo ${ }^{4}$}

$\mathrm{Na}$ chamada fase pré-científica da economia (durante a antigüidade grega e romana e Idade Média), os teóricos não apresentaram um conjunto de idéias sistemáticas e consistentes que poderiam ser consideradas científicas. A partir da metade do século XV, na era denominada Mercantilismo (1450-1750), tornou-se objetivo principal dos governantes europeus o aumento da riqueza e poder da nação, via comércio internacional (superávit da balança comercial, exploração das colônias e, principalmente, acúmulo de metais preciosos).

No final do século XVIII, a atividade econômica passa a ser tratada cientificamente. Surge na França a Fisiocracia, em torno de Quesnay (16941774) e sua obra Tableau Economique (1758). Como fonte de riqueza (de valor), a agricultura, por meio do fator "terra", substitui a indústria e o comércio. Para os fisiocratas, a fertilidade da terra torna produtivo o trabalho empregado no seu cultivo, diferentemente do que ocorre em outros setores de produção.

${ }^{4}$ Discussão baseada nos seguintes autores: Bernardes (2001), Kraemer (1983), Pinho (1996) e Souza (1997b). 
Assim, os trabalhadores do campo são os únicos responsáveis pela criação de excedentes.

Entre o final do século XVIII e meados do século XIX, sistematizamse as primeiras leis da economia política e surge a Economia Clássica ${ }^{5}$. Como marco, a obra de Adam Smith (1723-1790), "A Riqueza das Nações", pregava a "Ordem Natural" sob a qual o interesse individual manteria a economia funcionando eficientemente. O crescimento econômico era resultado da taxa positiva de lucro decorrente da ampliação do mercado e da divisão do trabalho. Dessa forma, Smith observou a importância da indústria na economia logo nas primeiras fases da Revolução Industrial. O produto total dependia do estoque de capital, do número de trabalhadores produtivos e do estoque de recursos naturais.

David Ricardo (1772-1823) ocupou-se da riqueza nacional e sua distribuição entre as classes. Discutiu sobre a fertilidade do solo e retorno econômico, quando observou o aumento do "capital" nas boas terras ao cultivar terras piores. Assim, incorporou a idéia da produtividade marginal decrescente ocorrida principalmente na agricultura, exatamente na margem extensiva de cultivo (terras menos férteis), atribuindo à atividade agrícola toda problemática do crescimento econômico. A função de produção ricardiana incorpora a variável estoque de conhecimentos além dos fatores considerados por Smith. Entretanto, o conceito de capital para Ricardo e seus contemporâneos ainda era restrito à idéia de manufaturado e determinado pela quantidade de trabalho (Bernardes, 2001).

\footnotetext{
${ }^{5}$ Aqui "Escola Clássica" corresponde ao grupo de economistas do fim do século XVIII e começo do século XIX, liderados por Adam Smith.
} 
Stuart Mill (1806-1873) discutiu sobre o uso mais eficiente do "capital conjunto". Este capital, representado pelas grandes sociedades anônimas, associações de produtores, cooperativas de produção e consumo, aperfeiçoava os processos produtivos, as atividades do comércio e serviço, ampliando os níveis de capital e produção. Sobre o estágio estacionário da economia, diferentemente dos seus contemporâneos, possuía uma visão otimista ao considerar os impactos positivos das inovações tecnológicas sobre 0 crescimento.

Marx (1818-1883), analisando o modo de produção capitalista, centraliza suas observações nas relações sociais de produção. Para esse autor, o modo como se relacionam os fatores econômicos tradicionais, adaptado às forças produtivas locais, criam estímulos que favorecem o desenvolvimento dos meios de produção, tornando-se também capital (Bernardes, 2001). Considerou o avanço tecnológico e a conseqüente substituição do homem pela máquina. Desenvolveu conceitos como acumulação de capital e concentração monopolista, dentre outros, no entanto, não discorreu sobre o "novo capital reprodutivo" (originário do lucro dos empresários e de seus reinvestimentos), fonte do processo de desenvolvimento dos países industriais.

Ao final do século XIX, observa-se transformações estruturais ocorridas nas economias e conseqüente presença do capitalismo "molecular" (as grandes concentrações). Nesse cenário, coube aos neo-clássicos ou marginalistas a elaboração de novos fundamentos teóricos que fossem capazes de explicar as inovações do período. Nas discussões teóricas, a análise marginal enfatizou os fatores de produção, ou melhor, a eficiência microeconômica da produção. Para eles, o produto final é o resultado da combinação entre trabalho, capital e recursos naturais, recursos escassos alocados objetivando resultados ótimos, equilibrando dispêndios e ganhos marginais. 
Uma das maiores contribuições de Walras (1834-1910) refere-se às investigações sobre a formação do produto. Ao considerar os bens finais como resultado da utilização dos fatores iniciais, observou que a produtividade marginal destes decresce à medida que for mais empregado. Com relação ao conceito de capital agrupou fatores diferentes, como máquinas, instalações, matérias-primas etc.

Marshall (1842-1924) considerou a economia como ciência do comportamento humano criando métodos de mensuração. Observou que a obtenção de ganho econômico move as motivações das pessoas, as quais podem ser medidas por meio da moeda, como denominador comum, método aplicado não a indivíduos, mas a grupos ou organismos sociais. Ademais, enfocou a acumulação do capital como fonte do crescimento da riqueza.

Wicksell (1851-1926) apresentou construções significativas à análise do valor e da distribuição. Discutiu sobre o papel da moeda e do crédito na atividade econômica e procurou analisar o efeito da acumulação de capital sobre a Renda Nacional. Dessa forma, integrou a análise monetária à análise real.

Os neoclássicos enfatizavam principalmente capital físico e financeiro em seus modelos de crescimento. A ausência de capital físico (infraestrutura, máquinas, equipamentos e benfeitorias) inerente ao processo produtivo era apontada como obstáculo crítico ao desenvolvimento. O princípio da produtividade marginal decrescente do capital financeiro trouxe contribuição significativa ao processo de crescimento econômico ao instigar a transferência do capital financeiro dos países ricos para os pobres, visto como única alternativa para ampliar sua produtividade. Esses teóricos também não consideravam os recursos naturais como fator importante para as economias (Bernardes, 2001). 
O "Institucionalismo" e a "Economia do Bem-Estar" representam os principais movimentos de oposição ao neoclassicismo. A Escola Institucionalista, liderada por Veblen (1857-1929), fundamentou seu arcabouço teórico na história, sociologia e outras ciências sociais. Na análise econômica, procurou considerar o tempo e o espaço. A "Economia do Bem-Estar", tendo Pigou (1877-1959) como principal representante, questionou os pressupostos clássicos e neo-clássicos da ausência do Estado no processo produtivo. Para tanto, Pigou procurou identificar situações que justificavam a presença do Estado na produção de bens e serviços necessários às comunidades, mas não lucrativos ao setor privado.

Precursor da teoria do desenvolvimento capitalista, Schumpeter (1883-1950) atribui à oferta papel fundamental no crescimento econômico. Este é garantido quando novos produtos e processos de produção forem adotados pelo empresário inovador. Como meios de produção, o trabalho, a terra, as inovações tecnológicas e o meio sócio-cultural foram relacionados. Também, dedicou atenção especial ao crédito bancário na concretização do investimento. Para Schumpeter, o conhecimento tecnológico, o treinamento de mão-de-obra, as instituições eficientes (principalmente as financeiras) e o "espírito" capitalista são os promotores do desenvolvimento.

Vários problemas decorrentes do final da Primeira Guerra Mundial e da crise de 1929 colocaram "em cheque" os fundamentos teóricos construídos até esse período. Keynes (1883-1946), instigado pela instabilidade de curto prazo, preocupou-se com as flutuações econômicas, os níveis de emprego e renda, aspectos macroeconômicos. Trouxe importante contribuição sobre o papel do investimento da política fiscal e monetária na atividade econômica. Nesse sentido, em suas análises desenvolvimentistas, Keynes considerou essencial a participação do Estado na economia. 


\subsubsection{Concepções recentes sobre o papel dos estoques de capitais na atividade econômica ${ }^{6}$}

A partir dos anos 30, além da difusão terminológica, ampliaram-se as discussões sobre papel dos estoques de capitais na economia. Observa-se que, nos modelos elaborados nesse período, o capital financeiro passou a ser visto como fator fundamental para o crescimento. Harrod $(1939)^{7}$ e Domar $(1946)^{8}$, por exemplo, relacionavam equilíbrio entre poupança e investimento ao crescimento do capital. Através das construções destes teóricos, aumento na taxa de poupança-investimento geraria crescimento, contestando as teorias da produtividade marginal do capital decrescente ou constantes (Bernardes, 2001).

O modelo de Solow (1956) ${ }^{9}$ adota alguns princípios de Harrod (1939) e Domar (1946). Supõe poupança igual ao investimento, sendo este responsável por novas unidades de capital físico. A poupança, a taxa de depreciação do capital, a dinâmica populacional e a força de trabalho são definidas exogenamente e a uma taxa constante, determinando a mesma dinâmica ao capital. Dessa forma, o modelo Solow (1956), sem progresso tecnológico, ao supor constante a taxa de crescimento da produção, não fornece explicações para os determinantes da ampliação do produto no longo prazo, em termos "per capita". Ao inserir a tecnologia, conclui que a mesma tem ampliado os níveis de capital e produto, gerando um efeito temporário e não de longo prazo nas taxas de crescimento "per capita". Assim, os modelos de tradição neoclássica atribuem papel preponderante para a tecnologia, que, apesar de exógena, é considerada a única força que de fato conta para o crescimento da renda "per capita", restando um papel relativamente pequeno

\footnotetext{
${ }^{6}$ As discussões dessa seção foram fundamentadas nos autores a seguir: Bernardes (2001), Silva Filho (1999) e Arraes \& Teles (2000).

${ }^{7}$ HARROD, R.F. An essay in dynamic theory. Economic Journal, v.49, p.14-33, 1939.

${ }^{8}$ DOMAR, E. Capital expansion, rate of growth and employment. Econometrica, April 1946.

${ }^{9}$ SOLOW, R.A.A contibution to the theory of economic growth. Quarterly Journal of Economics, v.70, p.65-94, 1956.
} 
para qualquer outro fator (Silva Filho, 1999; Bernardes, 2001; Arraes \& Teles, 2000).

Nos anos posteriores à década de 50 , outras pesquisas registraram observações pertinentes sobre os recursos financeiros. Tobin $(1965)^{10}$, atentando para o significado de capital financeiro, observou que a riqueza das unidades econômicas são distribuídas entre a moeda e o capital produtivo. Contudo, McKinnonn (1973) ${ }^{11}$ e Shaw $(1973)^{12}$ ressaltam que a repressão e, ou, distorções nos preços dos serviços financeiros afetam a quantidade e qualidade dos investimentos e esbarram o processo de crescimento (Bernardes, 2001).

É a partir dos anos 70 que a teoria do capital humano é desenvolvida. Não são recentes as discussões sobre a importância do trabalho como fator produtivo, embora não denominado como capital. A noção clássica de trabalho, a qual considerava idêntica a capacidade de todos os empregados resultou da dificuldade de tratar, explicitamente, os recursos humanos como um meio produzido de produção, como um produto de investimento, como uma forma de capital (Schultz, 1973).

Nos modelos de crescimento endógeno, além da mutação técnica, o capital humano é considerado como variável endógena e poderoso motor do desenvolvimento. Modelos como o de Lucas (1988) inseriu o capital humano como variável explicativa do crescimento econômico à medida que a qualificação de mão-de-obra aumenta a produtividade dos trabalhadores e, conseqüentemente, do processo produtivo. Esse autor inseriu na função de produção variáveis como fração de tempo dedicado ao trabalho, produtividade

\footnotetext{
10 TOBIN, J. Money and economic growth. Econometrica, v.33, n.4, p.671-684, 1965.

11 McKINNON, R.I. Money and capital in economic development. Washington, D.C.: Brookings Institution, 1973.

12 SHAW, E.S. Financial deepening in economic development. New York: Oxfore University Press, 1973.
} 
do tempo de trabalho, dedicação à educação e alocação de recursos para introdução de novos processos (Arraes \& Teles 2000; Bernardes, 2001).

"A característica distintiva do capital humano é a de que é ele parte do homem. É humano porquanto se acha configurado no homem, e é capital porque é uma fonte de satisfações futuras, ou de futuros rendimentos, ou ambas as coisas. Onde os homens sejam pessoas livres, o capital humano não é um ativo negociável, no sentido de que possa ser vendido. Pode, sem dúvida, ser adquirido não como um elemento de ativo, que se adquire o mercado, mas por intermédio de um investimento no próprio indivíduo...." (Schultz 1973, p.53)

Quanto ao aumento dos estoques em capital humano, pode-se considerar diversos tipos de investimentos. Os investimentos em escolaridade e educação de nível mais alto, treinamento realizado no local de emprego e investimentos em saúde e na aquisição de conhecimento e técnicas, empregados para a melhoria da qualidade e produtividade do esforço humano, são alguns relacionados. Pereira (2001) citando Blaug argumenta que “... o capital humano não implica dizer que as pessoas sejam tratadas como capital. Em outras palavras, o capital humano é o valor atual das habilidades adquiridas pelas pessoas e não o valor das próprias pessoas..." (Pereira 2001, p.10).

Deve-se notar que mensurar capital humano ainda não é tarefa simples. Aqueles investimentos ou gastos na verdade respondem por grande parte do volume dos rendimentos reais dos trabalhadores, mas que geralmente são considerados consumo e não investimentos, são tratados como deduções de uma acumulação potencial de capital e não são registrados na Contabilidade Nacional (Pereira, 2001; Bernardes, 2001; Schultz, 1973; Soubbotina \& Sheram, 2000). Contudo, os métodos de avaliação do capital humano, todavia, 
mesmo imperfeitos, permitem aos especialistas analisar algumas questões cruciais para o desenvolvimento, como a composição da riqueza nacional.

As discussões presentes nos modelos de crescimento endógeno não só enfatizam o papel do capital humano, inserem em suas digressões outros fatores. Romer $(1986)^{13}$, Lucas $(1988)^{14}$ e Barro \& Sala-i-Martin (1995) $)^{15}$ detectaram a complementariedade entre os capitais humano e físico, que associado à tecnologia, promovem externalidades positivas sobre a produtividade, elementos extremamente importantes para a compreensão dos níveis de crescimento (Arraes \& Teles 2000; Bernardes, 2001). Outros autores centralizaram seus estudos apenas no capital físico, como a pesquisa realizada por Aschauer (1989) ${ }^{16}$, que correlaciona os volumes de investimento em capital físico aos níveis de produtividade. Os resultados desse trabalho revelam que as vantagens comparativas de algumas regiões deve-se à abundância de energia, telecomunicações e transportes, infra-estrutura que reduz os custos de produção e incentivam a ampliação da capacidade produtiva (Arraes \& Teles, 2000).

Os conceitos de capital até aqui apresentados também são encontrados nas obras mais recentes da literatura econômica, as quais reforçam as definições e acrescentam outras variáveis relacionadas. Rossetti (1997) compreende capital como as mais diferentes categorias de riquezas acumuladas pela sociedade, empregadas na geração de novas riquezas. Troster \& Mochón (1999) englobam como capital diversos meios e, ou, instrumentos utilizados no processo produtivo. À noção de capital físico acrescenta-se edifícios, construções e tecnologias. Os fundos disponíveis para

\footnotetext{
${ }^{13}$ ROMER P. Increasing returns and long-run growth. Journal of Political Economy, v.94, p.1002-1037, 1986.

${ }^{14}$ LUCAS, R.E. On the mecanics of economic development. Journal of Monetary Economics, v.22, n.1, p.3-42, 1988.

${ }^{15}$ BARRO, R.J.; SALA-I-MARTIN, X. Economic Growth. New York: McGraw-Hill, 1995.

${ }^{16}$ ASCHAUER D.A Is public expenditure produtive? Journal of Monetary Economics, v.23, p.177-200, 1989.
} 
compra são considerados capital financeiro, assim como o volume de crédito, poupanças e títulos. No que diz respeito aos componentes inerentes ao capital humano, nenhuma inovação foi verificada, ou seja, os mesmos elementos são citados (Troster \& Mochón, 1999; Peres, 2000). Além disso, surgem outros fatores condicionantes do crescimento das economias mas que não podem ser relacionadas às "tradicionais" e anteriores concepções sobre estoque de capitais. Segundo Silva Filho (1999):

“... Neste sentido, os fatores como inovação tecnológica endógena (que surgem como resultado dos esforços dos agentes produtivos para maximizarem seus lucros), capital humano (ou seja, o 'estoque de conhecimento' dos agentes econômicos) e os arranjos institucionais (incluindo aí a política governamental e a organização da sociedade civil) passaram a assumir um papel crucial no crescimento contínuo da renda per capta em qualquer sistema econômico... É neste ponto em que se insere o papel fundamental exercido pelos atores sociais que comandam as políticas de desenvolvimento de economias subdesenvolvidas, sejam blocos econômicos de países, economias nacionais ou regiões dentro do país" (Silva Filho 1999, p.225).

Portanto, observa-se que ao longo dos anos a complexidade dos sistemas econômicos faz ampliar as discussões sobre fatores inerentes ao desenvolvimento. Por isso, nas próximas seções são delineadas, respectivamente, as concepções atuais sobre a importância do capital social e do capital natural na economia. 


\subsubsection{Concepções sobre o papel do capital social na economia}

\section{Conceito de capital social}

Recentemente são várias as contribuições à definição de capital social. De forma geral, a maioria dos estudiosos indicam que o capital social corresponde ao tecido social que mantém a coesão das sociedades através de uma rede de relacionamentos entre as pessoas e delas com os grupos sociais. Os elementos constitutivos do conceito de capital social referem-se à capacidade em subordinar interesses individuais aos de grupos maiores, visando objetivos comuns ou benefício mútuo. Essa interação social é baseada na confiança, valores e normas compartilhados para a formação, gestão de grupos, associações e organizações estáveis (Peres, 2000; Soubbotina \& Sheram, 2000; Woolcock, 2000; Sachs \& Lages, 2001).

Putnam (1996) examina apenas a relação associações horizontais e benefícios comunitários, o aspecto mais específico (limitado) do capital social. "O capital social diz respeito a características da organização social, como confiança, normas e sistemas, que contribuam para aumentar a eficiência da sociedade, facilitando as ações coordenadas" (Putnam 1996, p.177). Neste sentido, Putnam adentra na discussão sobre a "virtude cívica", fundamentado em Tocqueville e outros autores, e caracteriza a comunidade cívica como aquela composta por cidadãos atuantes e detentores de espírito público, em que a política se aproxima do ideal de igualdade. A teoria ajuda a explicar porque este componente do capital social, a participação cívica, favorece o desempenho do governo e da economia. A abordagem de Putnam é classificada como uma "visão limitada", por considerar as relações sociais como dadas no tempo (Putnam, 1996; Monasterio, s.d.; Zumbado, 1998, Nascimento, 2000).

A definição de Coleman (1990) é bem mais ampla que a de Putnam porque, além dos aspectos anteriormente relacionados, inclui outras formas, 
através das quais as relações sociais influem sobre a ação coletiva. Incorpora as associações do tipo vertical (as associações com relações hierárquicas, por exemplo) e considera o comportamento das entidades tais como as empresas (Monasterio, s.d.; Zumbado, 1998).

Fukuyama $(1995)^{17}$ examina os princípios sociais de várias sociedades sobre o que é denominado "virtudes sociais". Compreende que as instituições políticas e econômicas liberais dependem de uma sociedade civil dinâmica e saudável, tendo a confiança como o atributo cultural mais importante (Zumbado, 1998).

North $(1990)^{18}$ e seu enfoque neo-institucional incluem em seus trabalhos o ambiente social e político que permitem o desenvolvimento das normas e a configuração da infra-estrutura social. Vai mais além de Putnam e Coleman ao incorporar não só as relações informais, horizontais, locais e hierárquicas, mas também as relações formais e institucionalizadas e as estruturas como o governo, o regime político, o estado de direito, o sistema judicial e liberdades civis e políticas (Zumbado, 1998).

Flores \& Rello $(2001)^{19}$ objetivam contribuir para o delineamento rigoroso e consensual do conceito de capital social. Procuram apresentar, num esquema, as discussões recentes sobre esse tema. Todavia, observam que a maioria dos trabalhos não tem apresentado, de forma clara, a definição de capital social. Muitos têm optado por definições funcionais, dificultando o entendimento de tal conceito. Uma solução seria, então, diferenciar fontes, formas, funções, dimensões e resultados do capital social. Nesse propósito,

\footnotetext{
17 FUKUYAMA, F. Trust: the social virtues and the creation of prosperity. New York: Free Press Books, 1995.

18 NORTH, D. Institutions, institutional change and economic performance. Cambridge: Cambridge University Press, 1990.

${ }^{19}$ Flores \& Rello apresentaram o artigo "Capital Social Virtudes e Limitações" na Conferência Regional sobre Capital Social e Pobreza, organizada pela CEPAL e Universidade do Estado de Michigan, Santiago do Chile. Margarida Flores é diretora adjunta da CEPAL no México e consultora da CEPAL. Uma versão anterior foi apresentada no XXIII Congresso Internacional da Associação de Estudos Latino Americanos, em Washington no ano de 2001.
} 
procuram, então, conciliar cada aspecto abordado pelas concepções mais difundidas, descritas no Quadro 1, concluindo que "capital social é a capacidade de ação coletiva que possibilita a criação de certos componentes sociais, com a finalidade de obter benefícios comuns..." (Flores \& Rello 2001, p.5). Segundo esses autores, a magnitude do capital social depende:

- da fontes (normas, redes e ações) e da infra-estrutura (condições externas: instituições sociais e condições internas: reprodução e manutenção da confiança no grupo); e

- das formas de sua utilização. Se o capital social se sustenta em redes e organizações fortes, pode alcançar empresas sociais complexas, e seu raio de ação será maior ou vice-versa. 


\begin{tabular}{|c|c|c|c|}
\hline Autor & Fontes e infra-estrutura & Ações coletivas & Resultados \\
\hline $\begin{array}{l}\text { Coleman } \\
(1990)\end{array}$ & $\begin{array}{l}\text { Aspectos da estrutura } \\
\text { social }\end{array}$ & $\begin{array}{lrr}\text { que } & \text { facilitam } & \text { certas } \\
\text { ações } & \text { comuns } & \text { dos } \\
\text { atores } & \text { dentro } & \text { da } \\
\text { estrutura } & & \\
\end{array}$ & \\
\hline $\begin{array}{l}\text { Bourdieu } \\
(1985)\end{array}$ & $\begin{array}{l}\text { Redes permanentes } \mathrm{e} \\
\text { participação em um } \\
\text { grupo }\end{array}$ & & $\begin{array}{l}\text { que asseguram a seus } \\
\text { membros um conjunto de } \\
\text { recursos atuais ou } \\
\text { potenciais }\end{array}$ \\
\hline $\begin{array}{l}\text { Putnam } \\
\text { (1993) }\end{array}$ & $\begin{array}{lr}\text { Aspectos } & \text { das } \\
\text { organizações } & \text { sociais, } \\
\text { tais como as redes, as } \\
\text { normas e a confiança }\end{array}$ & $\begin{array}{l}\text { que permitem a ação e a } \\
\text { cooperação }\end{array}$ & $\begin{array}{l}\text { para benefício mútuo } \\
\text { (desenvolvimento } \\
\text { democracia) }\end{array}$ \\
\hline $\begin{array}{l}\text { Woolcock } \\
\text { (1998) }\end{array}$ & Normas e redes & $\begin{array}{l}\text { que facilitam a ação } \\
\text { coletiva }\end{array}$ & e o benefício comum \\
\hline $\begin{array}{l}\text { Fukuyama } \\
\text { (1995) }\end{array}$ & $\begin{array}{l}\text { Recursos morais, } \\
\text { confiança e mecanismos } \\
\text { culturais }\end{array}$ & $\begin{array}{l}\text { que reforçam os grupos } \\
\text { sociais }\end{array}$ & \\
\hline $\begin{array}{l}\text { Neo- } \\
\text { weberianos }\end{array}$ & Laços e normas & $\begin{array}{l}\text { que ligam os indivíduos } \\
\text { dentro das organizações }\end{array}$ & \\
\hline $\begin{array}{l}\text { Banco } \\
\text { Mundial } \\
\text { (1998) }\end{array}$ & $\begin{array}{l}\text { Instituições relações, } \\
\text { atitudes e valores }\end{array}$ & $\begin{array}{l}\text { que governam } \\
\text { interação de pessoas }\end{array}$ & \begin{tabular}{|ll} 
e facilitam & o \\
desenvolvimento \\
econômico e \\
democracia
\end{tabular} \\
\hline
\end{tabular}

Quadro 1 - Definições de capital social selecionadas e classificadas de acordo com as fontes, as ações coletivas praticáveis e seus resultados.

Fonte: Flores \& Rello (2001)

O Banco Mundial considera os diversos conceitos como dimensões complementares e não-excludentes do mesmo processo. Assim, uma combinação desses caminhos facilita adaptações e amplia as possibilidades da aplicação teórica em situações específicas. Segundo Zumbado (1998):

"... conforme mais se amplia a definição do conceito [de capital social], e mais complexidade se incorpore em sua análise, mais pode chegar a refletir todas as esferas das 
estruturas sociais. Assim, a teoria mais ampla oferece 0 espaço necessário para desenvolver propostas receptivas, maleáveis e exaustivas. Estas deveriam considerar as complexidades e diferenças das estruturas, assim evitando os erros cometidos pelas anteriores teorias e políticas de desenvolvimento que surgem da omissão das variações e combinações do quarto elemento que pode constituir a riqueza das nações: seu capital social" (Zumbado 1998, p.189).

Como observado, na maioria dos casos o conceito de capital social é definido por sua função e até mesmo por sua operacionalidade, o que amplia seu significado. Embora responsável por um repertório semântico, sem dúvidas é bem-vinda a generalização típica dos fundamentos teóricos catalisadores dos vários atributos e situações.

\section{Medidas do capital social}

Embora não haja uma forma única, é possível medir o capital social. A multiplicidade de aspectos que envolvem a definição do capital social possibilita aos pesquisadores medi-lo de diversas formas ou através de diversas variáveis. "Os dados utilizados nestes cálculos no geral refletem a confiança das pessoas, no governo e nas instituições públicas, a participação em organizações cívicas e o acesso a informação" (Soubbotina \& Sheram 2000, p.10).

Para operacionalizar o conceito de capital social, o Serviço Brasileiro de Apoio às Micro e Pequenas Empresas (SEBRAE) sugere descrever as relações sociais que direta e indiretamente implicam repercussões econômicas. As relações sociais diretas referem-se à captação de formas relacionais formal ou informalmente estabelecidas através de organismos, instituições ou diferentes expressões da sociedade organizada. As relações sociais indiretas 
englobam as regras e normas que geram confiança e reciprocidade, criam as pré-condições para as formas de produzir e agir. Nesse sentido, podem-se incluir nas análises locais os elementos intangíveis que dão coesão social como a cultura, as tradições, a história etc. (Sachs \& Lages, 2001) ${ }^{20}$.

$\mathrm{Na}$ elaboração de trabalhos empíricos, é preciso ter alguns cuidados no processo de mensuração do capital social. A bem verdade, as concepções de capital social relacionam certos elementos intangíveis sobre os quais se pode eleger proxies, contudo estas podem ser questionáveis. Também, é preciso atentar para a escolha de definições e indicadores, já que esses podem conduzir a juízos de valor, como a apresentada por Putnam, que considera apenas as associações positivas (Monasterio, s.d.; Zumbado, 1998).

Os economistas têm dado maior atenção a definições que incluem as estruturas de redes e relações sociais, mas também englobam as disposições comportamentais (como confiança, reciprocidade, honestidade) e medidas de qualidade institucional ("códigos de leis", "contrato obrigatório", "liberdades civis" etc.). Essas abordagens, ao trabalhar com séries de dados nacionais, permitem, por exemplo, que capital social seja inserido nas regressões de crescimento macroeconômico, ampliando sua capacidade de aplicabilidade (Woolcock, 2000) ${ }^{21}$.

\footnotetext{
${ }^{20}$ Sachs \& Lages apresentaram o artigo: "Capital social e desenvolvimento: novidade pra quem?" na Conferência Regional sobre Capital Social e Pobreza organizado pela CEPAL e Universidade do Estado de Michigan em Santiago do Chile. Sachs é co-diretor do Centro de Pesquisa sobre o Brasil Contemporâneo da Escola de Altos Estudos em Ciências Sociais de Paris. Lages é Assessor-Chefe da presidência do SEBRAE.

${ }^{21}$ Woolcock apresentou o paper entitulado "The place of social capital in understanding social and economic outcomes" no Simpósio Internacional sobre "The Contribution of Human and Social Capital to Sustained Economic Growth and Well-Being, organizado por Human Resources Development Canada and the OECD.
} 


\section{Capital social como recurso individual}

Há séculos, a relação entre os interesse individuais e o bem-estar geral permeiam as discussões formais. Para os clássicos e neoclássicos, a busca de benefícios próprios resultaria em bem-estar social, mas, ao longo do processo histórico, Marx e outros teóricos refutaram este princípio e, atualmente, muitos estudiosos têm contribuído para o melhor entendimento de tais relações. Coleman (1990) descreve os benefícios individuais da coesão social ao afirmar que:

"... relações de autoridade, relações de confiança e alocações consensuais de direitos que estabelecem as normas ... existem quando os indivíduos tentam fazer o melhor uso destes recursos individuais ... necessita não apenas serem vistos como componentes das estruturas sociais, entretanto. Também podem ser vistos como recursos para os indivíduos... o conjunto composto daqueles recursos é definido pelo termo Capital Social. [Capital Social] não é uma entidade singular, mas uma variedade de diferentes entidades que possuem duas características em comum: consistem em algum aspecto de uma estrutura social e facilitam algumas ações dos indivíduos que estão no interior desta estrutura..." (Coleman 1990, p. 300 e 302).

São diversos os ganhos que o investimento em capital social pode

trazer a cada pessoa. As relações familiares, as organizações sociais comunitárias podem ser utilizadas para o desenvolvimento cognitivo ou social das crianças e pessoas jovens, que resulta em melhores níveis de sistemas comportamentais e maior desenvolvimento do seu capital humano. O capital social simplesmente reflete a realidade das relações sociais como um dos meios para lutar contra a incerteza. Por exemplo, pode facilitar o acesso dos 
pobres ao mercado de crédito, melhorar a qualidade dos serviços do governo e das escolas públicas, assegurar um bom trabalho, alcançando vantagens que não se poderiam obter com sua ausência, gerando benefícios principalmente individuais (Coleman, 1990; Woolcock, 2000, Monasterio, s.d.; Abramovay, 2000).

Abramovay (2000) lembra o exemplo dos fundos formados por associações de agricultores que lhes permitem acesso ao crédito bancário, recursos muitas vezes individualmente inacessíveis. Nesses sistemas, diferentemente do mercado de crédito convencional, ao invés de bens físicos, o capital social representa a garantia. O capital social é uma espécie de garantia, diferentemente do mercado de crédito convencional em que bens físicos representam esta garantia. Então, a rede de confiança entre os próprios agricultores e com os bancos é considerada como um ativo social capaz de propiciar renda a cada um produtor envolvido no processo.

\section{Capital social e atividade econômica}

Um estoque de capital social suficiente é uma das premissas para o bom desempenho da atividade econômica. A confiança e a cooperação facilitam $o$ entendimento entre indivíduos ou firmas $e$ as transações econômicas. Como exemplo, têm-se as redes de pequenos negócios, que permitem reduzir custos, aumentar o volume de créditos e a eficiência e alcançar economias de escala e competitividade. É preciso perceber que as ações dos agentes econômicos estão inseridas numa rede de relações sociais, em que as escolhas dos indivíduos e a organização das atividades estão inseridas (Peres, 2000; Soubbotina \& Sheram, 2000; Sachs \& Lages 2001; Monasterio, s.d.; Abramovay, 2000).

Observou-se que as interpretações sobre a importância do capital social na economia, presentes nos trabalhos acadêmicos, possuem alguns pontos em comum: 
“...Primeiro, todas as teorias tomam uma postura integral, e tratam de incluir as esferas do político, o social e o econômico em um conjunto integrado... Em segundo lugar, todos os enfoques consideram a relação dos atores econômicos entre si e com suas organizações, sejam formais ou informais, melhoram a eficiência das atividades econômicas..." (Zumbado 1998, p.184).

\title{
Capital social como capital/recurso e fator de produção
}

O capital social apresenta aspectos que o interliga à concepção de capital: além de demandar investimento, é um recurso tratado como fator de produção. O estoque de capital social depende de investimentos como as outras formas de capital, embora guarde consigo algumas peculiaridades. As pessoas devem dedicar tempo e esforço para constituição e manutenção de redes de relações sociais. Esta é a forma sob a qual o capital social é produzido, instituído. Porém, diferentemente do capital físico, por exemplo, a acumulação de capital social não depende de "sacrifícios presentes" (poupança) para a obtenção de ganhos futuros. Ademais, ele não se deprecia como o uso, ao contrário, a tendência é que, quanto mais interação entre os indivíduos, maior a disponibilidade de capital social (Coleman, 1990; Peres, 2000; Monasterio, s.d.; Nascimento, 2000). Segundo Putnam,

\begin{abstract}
"Os estoques de capital social, como confiança, normas e sistemas de participação, tendem a ser cumulativos e a reforçar-se mutuamente. Os círculos virtuosos redundam em equilíbrios sociais com elevados níveis de cooperação, confiança, civismo e bem-estar coletivo..." (Putnam 1996, p.186).
\end{abstract}

Ainda, "... A acumulação de capital social é um processo de aquisição de poder ("empowerment")..." (Abramovay 2000, p. 384). O "empoderamento" 
ocorre quando a coletividade fortalece os laços de coesão, adquirindo, por meio destes, poder e capacitação para o autodesenvolvimento (Nascimento, 2000).

Capital social é produtivo porque, como recurso, pode gerar fluxos e permitir o alcance de certos objetivos que, com sua ausência, não seriam possíveis. Na linguagem econômica, o termo segue o sentido empregado às outras formas de capital (Coleman 1990; Sachs \& Lages 2001, Monasterio, s.d.). De acordo com Abramoway (2000), citado por Sachs \& Lages (2001), capital social "... refere-se ao conjunto de recursos capazes de promover a melhor utilização dos ativos econômicos pelos indivíduos e pelas empresas" (Sachs \& Lages 2001, p.6).

Considerado um fator produtivo, alguns trabalhos, como o de (Monasterio, s.d.), têm incorporado o capital social como um argumento da função de produção, analisado juntamente com outros fatores. Em termos gerais, a função de produção é composta pelo fator físico $(K)$, trabalho $(L)$, capital humano $(H)$ e capital social $(Q)$ :

$Y=F(K, L, Q)$, onde $\partial Y / \partial Q>0$

Formalmente, ter-se-ia o seguinte:

$Y=Q \cdot F(K, L, H)$, onde $Q>0$

Nessa especificação, um acréscimo no estoque de capital social, com o mesmo estoque de capital humano e físico, trabalho e tecnologia, elevaria a função de produção, da forma equivalente à do progresso técnico, ou seja, através de um aumento apenas no estoque de capital social, seria possível produzir uma quantidade maior de bens e serviços, ocasionado pela maior eficiência no uso dos demais recursos produtivos (Monasterio, s.d.; Zumbado, 1998; Woolcock, 2000). 


\section{A relação capital social e crescimento/desenvolvimento econômico}

Ao longo das últimas décadas, vários fatores abalaram os fundamentos das teorias do crescimento/desenvolvimento econômico. As crises financeiras e o empobrecimento de algumas economias, dentre outros problemas observados no período, colocaram em xeque as digressões ortodoxas. Atentar para as linhas de crédito, incentivos fiscais e investimentos em formação bruta de capital fixo não era suficiente para a compreensão da "performance" das economias. Assim, "...construiu-se um consenso em torno da idéia de que é insuficiente considerar apenas os aspectos materiais, tangíveis, da vida econômica..." (Monasterio s.d., p.1) (Verschoore Filho, 2000; Monasterio, s.d.).

Para ampliar a visão além dos aspectos materiais, surge a teoria de desenvolvimento endógeno. Sua principal questão foi entender o porquê do crescimento econômico diverso entre regiões e países, mesmo dispondo de estoques semelhantes dos recursos produtivos (financeiro, tecnológico, humano...). A resposta foi assentada na sociedade civil, compreendida nas formas locais de integração social, cívica e sua capacidade de mobilizar seus fatores de produção, conduzindo seu próprio desenvolvimento. Não fazia mais sentido enfatizar apenas aquelas variáveis, mas era preciso dar atenção aos aspectos sociais das comunidades (Verschoore Filho, 2000; Monasterio, s.d.).

Abramovay (2000) também enfatiza o tecido social nas análises do denominado "desenvolvimento territorial". A idéia é que o território regional ou nacional é mais que a simples base física compreendida, por exemplo, pelos atributos naturais, meios de transportes e comunicações, tecnologia, elementos tangíveis; "... um território representa uma trama de relações com raízes históricas, configurações políticas e identidade" (Abramovay 2000, p.385).

Vários pesquisadores observaram que o capital social tem auxiliado na compreensão das variadas "performances" das economias. As relações 
econômicas estão dispostas no tecido social e cultural, de maneira que a interação e cooperação entre os indivíduos por meio de redes sociais, associações cívicas e instituições (formais e informais), influem sobre a maneira de confrontar a pobreza, a vulnerabilidade, o oportunismo. Também, influem sobre a utilização eficiente dos recursos produtivos, sobre a forma de organização e distribuição de informações, a tomada de decisões e a coordenação de atividades que determinam o nível de desenvolvimento local (Peres, 2000; Soubbotina \& Sheram, 2000; Sachs e Lages, 2001; Woolcock 2000; Zumbado, 1998; Monasterio, s.d.). Nesse sentido, Coleman e Putnam trouxeram contribuições adicionais. Incluem proxies para o capital social em suas regressões de crescimento. Em linhas gerais, os testes corroboram a hipóteses de que o capital social influencia, positivamente, o desempenho econômico das regiões e países (Monasterio, s.d.).

"... o capital social se define como o ativo que determina a maneira como os atores econômicos interagem entre si e como se organizam para gerar crescimento $\mathrm{e}$ desenvolvimento. Em outras palavras é esse componente que permite que distintos países com dotações econômicas similares alcancem rendimentos econômicos diferentes, que implicam graus diversos de desenvolvimento e de desigualdade" (Zumbado 1998, p.177)

Os países que não alcançaram o desenvolvimento social têm grandes dificuldades para se expandir economicamente. A concentração de renda e dos ativos produtivos, bem como a ausência de instituições e contratos imparciais que dificultam o exercício da cidadania, constituem alguns dos empecilhos do desenvolvimento econômico de algumas localidades (Zumbado, 1998; Sachs \& Lages 2001). 
"Não deve surpreender que, segundo alguns estudos, os países com alto nível de corrupção tem taxas de crescimento econômico mais baixos. Alguns elementos do capital social, tais como o bom exercício do poder e do direito, são tão importantes para o desenvolvimento econômico como certas condições econômicas básicas, por exemplo, a existência de uma poupança e um investimento suficientes ou de fortes incentivos para a eficiência" (Soubbotina \& Sheram 2000, p.12)

Por fim, faz-se necessário pincelar algumas observações acerca do capital social. Em toda sua magnitude, o capital social não só compreende benefícios, dado que o potencial criado pelas relações sociais também implicam em perigo. Nas situações reais, as contradições e os conflitos podem implicar na busca de alternativas de curto prazo, em estratégias individualistas e clientelistas e em leis nepóticas. Igualmente, as regras de adesão, a colaboração e confiança observadas na organização de grupos marfiosos ou terroristas são exemplos claros de manifestações negativas de um certa dimensão do capital social (Sachs \& Lages, 2001; Woolcock, 2000; Zumbado, 1998). Coleman, atento a estas variantes, ampliou a definição do conceito de capital social ao incluir na sua abordagem as diversas associações e respectivos objetivos, seja positivo ou negativo. Ademais, é preciso estar atento ao fato de que "... uma forma dada de capital de capital social que é valiosa para facilitar certas ações pode ser inútil ou ser danosa para outras ações" (Zumbado 1998, p.179). Isso pretende evidenciar que as soluções não devem ser transponíveis e sim resultado de releitura, interpretação e adaptação a uma situação específica. 


\subsubsection{Concepções sobre o papel do capital natural na economia}

\section{A relação recursos naturais e economia: uma síntese das considerações desde os clássicos}

$\mathrm{Na}$ era clássica, a importância das características naturais foi relativizada. Como visto, os clássicos identificaram três fontes e componentes da riqueza nacional: terra, trabalho e capital, a chamada classificação tripartida dos fatores de produção. Nas análises sobre o desenvolvimento econômico, as inovações tecnológicas, ocorridas no período, contribuíram para o relativo desinteresse sobre o papel dos recursos naturais (restrito à terra). Contudo, é preciso observar que Ricardo centrou suas discussões sobre a determinação do valor ao comparar os diferentes níveis de fertilidade do solo e existência da renda da terra, ou seja, as análises eram realizadas considerando as características naturais (Bernardes, 2001; Souza, 1997b).

Ao longo de vários anos, teorias e modelos de crescimento não consideravam ou relativizavam as questões naturais no processo de produção. Para Harrod (1939) e Domar (1946), o gasto com investimento era o fator impulsionador imediato do produto e da renda agregada. Solow (1956) argumentou que a substituição de capital por trabalho no processo de produção é que poderia permitir um crescimento estável. Outros economistas neoclássicos trataram a natureza como qualquer outro recurso escasso e não como um bem público (Seják, s.d.; England, 1998).

A emergência de movimentos ambientais dos anos 50 e os choques nos preços da energia global, como a crise do petróleo na década de 70 , ampliaram o debate sobre a base natural. Nesse período, a teoria econômica 
neoclássica sobre a natureza precisou ser revisada. Meadows et al (1972) 22 apontaram a existência de "limites de crescimento" biofísico que eventualmente afetariam o crescimento econômico. Nesse ínterim, os modernos teóricos do crescimento começaram a incorporar os recursos naturais e poluição dentro dos seus modelos. Stiglitz $(1974)^{23}$, por exemplo, propôs uma função de produção agregada composta pelo fator trabalho, bens de capital e recursos naturais como substitutos na produção (Seják, s.d.; England, 1998).

Nos anos 80 , o otimismo tecnológico veio dominar a teoria sobre a relação entre o crescimento econômico e o mundo natural. Para Baumol $(1986)^{24}$, a tecnologia era capaz de ampliar as quantidades físicas e declinantes dos recursos naturais existentes, contribuindo para o aumento da participação daqueles recursos na atividade econômica (England, 1998).

Nos anos 90, amplia-se a possibilidade de esgotamento dos recursos naturais e, conseqüentemente, antigos preceitos são reformulados. Economistas ecológicos reconheceram explicitamente o papel essencial do meio ambiente na produção de mercadorias. Daly $(1994)^{25}$ apontou para o clima e depósitos minerais e Ayres $(1996)^{26}$ referiu-se aos aqüíferos e à camada de ozônio como formas específicas de recursos. Nesse período, a questão da "sustentabilidade" do desenvolvimento já se encontrava bastante difundida.

\section{Origem do conceito de desenvolvimento sustentável}

A partir do início dos anos 70, diversos trabalhos e eventos ampliaram as discussões ambientalista acerca do padrão de desenvolvimento

\footnotetext{
22 MEADOWS, D. et al. The limits to growth. New York: Universe Books, 1972.

${ }^{23}$ STIGLITZ, J. Growth with exhaustible natural resources: eficient and optimal growth paths. Review of Economic Studies, 1974, p.123-137.

24 BAUMOL, W. On the possibility of continuing expansion of finite resources. Kyklos, v.39, p.167-179, 1986.

${ }^{25}$ DALY, H. Operationalizing sustainable development by investing in natural capital. Washington: Island Press, 1994.

${ }^{26}$ AYRES, R. Limits to the growth paradigm. Ecological Economics v.19, p.117-134, 1996.
} 
sócioeconômico, contribuindo para a elaboração do conceito de desenvolvimento sustentável. O Relatório Meadows, em 1972, expressou a posição do Clube de Roma, apresentando a teoria do "crescimento zero", ao apontar para os limites do crescimento econômico estabelecidos pela finitude dos recursos naturais. A reunião de Estocolmo de 1972 lançou o conceito de Ecodesenvolvimento, segundo o qual é possível e necessário o desenvolvimento econômico compatível à preservação do meio-ambiente. Em 1979, também em Estocolmo, discutiu-se o conceito de Desenvolvimento Sustentável, o qual foi difundido em 1987 através do "Relatório Brundtand, Our Common Future", documento realizado pela comissão Mundial sobre Meio Ambiente e Desenvolvimento das Nações Unidas. Esse documento descreve que o desenvolvimento econômico deve observar a eficiência econômica, a eqüidade, e as questões ecológicas e garantir o desempenho futuro; o desenvolvimento deve ser sustentável. Porém, a consagração desse conceito deu-se na Conferência Mundial sobre Meio Ambiente e Desenvolvimento realizada no Brasil em 1992, denominada Rio 92. A "Agenda 21", elaborada neste evento, determinou as bases científicas e políticas necessárias a serem seguidas por cada país na concretização do crescimento com preservação da natureza (Amazonas, s.d.; Motta, 1997).

Nos últimos anos, o conceito de desenvolvimento sustentável tem se tornado mais amplo e mensurável. A sustentabilidade de uma economia ocorre quando se mantém não-declinantes os valores dos ativos (ou estoques de capitais), dado que são estes que definem o fluxo de bens e serviços futuros (Motta, 1997; Soubbotina \& Sheram, 2000). Segundo estudos do Banco Mundial:

“ ...o desenvolvimento sustentável se definiu como o processo de administração de um carteira de ativos para preservar e melhorar as oportunidades das pessoas. Os ativos a que se refere esta definição incluem não só o capital físico tradicional 
como também o capital natural e humano..." (Soubbotina \& Sheram 2000, p.11).

Assim, observa-se que o termo capital natural tem sido empregado nas discussões mais recentes sobre o papel dos recursos naturais na economia. Mas qual é a definição intrínseca ao termo capital natural?

\section{Capital natural: conceito}

"O conceito de capital natural é uma extensão da tradicional noção econômica de capital, que é geralmente definida como produtos manufaturados dos meios de produção, por exemplo as maquinarias, instrumentos, equipamentos, construções e assim por diante. O que o capital natural e o capital manufaturado tem em comum é que ambos sujeitam à definição de capital como um estoque (coleção, agregado) de algo que produz um fluxo (um produto periódico) de valores de bens ou serviços... Um estoque de maquinarias de uma fábrica produz um fluxo de roupas ou automóveis. Um estoque de árvores (por exemplo, uma floresta) produz um fluxo de bens na forma de novas árvores e um fluxo de serviços na forma de oxigênio, controle da erosão, habitat na vida selvagem, etc. Como notado anteriormente, nós podemos contabilizar os fluxos como renda. A depleção dos estoques, entretanto, é chamado de consumo de capital" (Prugh 1995, p.1).

O entendimento completo e acabado da definição de capital natural requer o conhecimento pormenorizado dos seus componentes, funções, tipos ou categorias. Com relação aos elementos considerados componentes do capital natural England (1998) cita: a superfície não depreciada da terra; o recurso solar (ou talvez seu valor capitalizado); a área das populações de 
organismos não-produzidos (cada população representando uma espécie biológica particular) e organizadas dentro de vários ecossistemas; e a área dos estoques de material nas crosta terrestre e atmosfera, campo de materiais naturais e de contenção de produtos desgastados.

Citando Pearce, Seják (s.d.) identificou quatro principais funções do ambiente natural: oferta de recursos naturais utilizados para criar bens econômicos; recepção de depósitos, dos materiais da atividade econômica que são dispostos no ambiente natural; oferta de "bens naturais" como selva, desertos e uma variedade de ecossistemas; e manutenção da vida.

No que diz respeito aos tipos, o capital natural pode ser dividido em duas maiores categorias: capital natural renovável e capital natural nãorenovável e uma categoria híbrida. Capital natural renovável (como o ecossistema, por exemplo) continuamente se mantém e se regenera por ele mesmo, por isto produz um fluxo pronto de bens e serviços que é essencialmente ilimitado. Entretanto, o volume do fluxo é finito. Dessa forma, o uso excessivo deste pode prejudicar sua capacidade de regeneração e de sustentação do fluxo de bens e serviços. O capital natural não-renovável, por definição, é exatamente o oposto da categoria anterior. Seus estoques (a maioria dos combustíveis fósseis e depósitos minerais, por exemplo) são finitos, mas a manutenção da taxa de fluxo é uma questão de gestão política. A categoria híbrida ou capital natural cultivado inclui todo o sistema de agricultura e aqüicultura, componentes não inteiramente produzidos pelo homem, mas também não são inteiramente natural, ou seja, este possui características de capital natural e de capital manufaturado. Os humanos criam capital natural cultivado por tomar os elementos do capital natural e os transformar de modo que eles funcionem através de meios tais como geração seletiva e uso de monoculturas (Prugh, 1995; Ayres et al., 1996). 


\section{Análises recentes sobre a relação capital natural e atividade econômica}

Cada vez, mais os estoques de capital natural têm se depreciado, principalmente como resultado das práticas econômicas. Para tanto, basta verificar o nível de extração dos combustíveis fósseis, erosão do solo decorrente de práticas agrícolas inadequadas, poluição do ar e respectiva perda da camada de ozônio, poluição das águas dos mares, rios, manguezais etc. Os índices de degradação por si só já são suficientes para comprovar o grau de comprometimento das ações atuais na garantia da manutenção de vida futura. England (1998) descreve que o capital natural consiste numa variedade de serviços e materiais essenciais para a economia, mas também enfatiza que:

"... certamente, a escala de atividade econômica é restringida pelo permanente estoque de capital natural e pela sua produtividade... Crescimento continuado de renda per capta também tende a ocorrer se o capital natural for preservado e se a transformação tecnológica favorecer o crescimento de sua produtividade" (England 1998, p.8).

Portanto, é preciso estar atento a que o capital natural não segue a mesma lógica intrínseca às formas de capital que podem ser produzidas, como o capital físico. O uso sem limites dos recursos naturais pode comprometer o desenvolvimento sócioeconômico. “... o capital natural tende a decrescer e impor restrições ao crescimento futuro criando consequentemente condições de não-sustentabilidade ao crescimento ou ao bem-estar de gerações futuras" (Motta 1997, p.4).

Quando se trata de países em desenvolvimento, cujas economias são dependentes de recursos primários, permanece imperativo a preservação. Só esse caminho pode garantir qualidade de vida dos seus cidadãos, além de ganhos de exportação contínuos. Países que possuem amenidades ambientais 
e uma industria turística crescente também devem estar priorizando a exploração dos recursos naturais de forma sustentável (Prugh, 1995).

\section{Indicadores de sustentabilidade ${ }^{27}$}

Um indicador de sustentabilidade reconhecido é o desenvolvido por Pearce e Atkinson ${ }^{28}$ (P\&A) em 1993). Sua abordagem considera a economia bruta, ao invés de investimentos, para contabilizar o excedente ou o déficit em dada conta corrente de um país. O índice P\&A contabiliza o consumo e a depreciação do capital fixo ou manufaturado, como também o consumo e a depleção de recursos naturais. Por essa estimativa, uma economia é sustentável se e somente se o índice de sustentabilidade for maior que zero (0), o que significaria que a renda bruta da economia excede o valor total do capital dissipado (Torras, 2000).

Os especialistas do Banco Mundial estão elaborando um novo indicador de sustentabilidade denominado "taxa de poupança natural" ou "taxa de investimento natural". Essa estimativa teria como objetivo ajustar a taxa de poupança tradicional, deduzindo do seu montante o valor estimado da poluição e degradação dos recursos naturais (Soubbotina \& Sheram, 2000). Segundo análises daquele órgão:

“... a maioria dos países que mais dependem dos recursos naturais tem taxas de poupanças baixas ou negativas. Se não se toma medidas firmes para invertê-las, essa tendência redundará em um largo prejuízo do bem-estar da população. As únicas regiões 'seguras' do mundo em desenvolvimento

\footnotetext{
${ }^{27}$ As fórmulas referentes ao indicador de sustentabilidade são encontradas em Torras (2000).

28 PEARCE, DW.; ATKINSON, G. Capital theory and the measurement of sustainable development: an indicator of "weak" sustainability. Ecological Economics, v.8, p.103-108, 1993.
} 
parece ser a Ásia Meridional, a Ásia Oriental e o Pacífico, onde as taxas de poupança natural foram positivas entre 1970-1993 e, em alguns casos, chegaram a 15\% do PNB. Nos países desenvolvidos ditas taxas foram de 10\% durante grande parte deste período" (Soubbotina \& Sheram 2000, p.13).

\section{Relacionando capital natural às formas "tradicionais" de capital}

Identificar e avaliar o fluxo de bens e serviços advindos da natureza permite torná-los semelhante aos insumos de capital tradicionais. Esse caminho possibilita incorporar os recursos naturais nos modelos econômicos tradicionais e estimar os indicadores de sustentabilidade, bem como auxilia as análises sobre os fatores determinantes do crescimento e desenvolvimento econômico. A concepção dos recursos naturais como um agregado definível economicamente é apresentada por vários estudiosos da área. Grande parte do desenvolvimento teórico e metodológico surge das contribuições da economia neoclássica e dos denominados economistas ecológicos (Seják, s.d.; Lima, 1999).

A Economia Neoclássica elaborou duas diferentes abordagens para o tratamento da questão ambiental, empregado dependendo da relação que os recursos naturais guardem com o processo produtivo. A primeira abordagem, a "Economia da Poluição", analisa os recursos ambientais no seu papel de depositário de rejeitos, outputs indesejáveis dos processos produtivos. Já a segunda abordagem, a "Economia dos Recursos Naturais", analisa os recursos ambientais no seu papel de matéria-prima, de inputs para os processos produtivos (Amazonas, s.d.). 


\section{Medidas do capital natural}

\section{Valoração do capital natural (via mercado)}

Com relação à valoração do capital natural, em geral, os métodos desenvolvidos até o período trazem contribuições importantes, a despeito de suas limitações. A incerteza se faz presente ao tratarem de um sistema que é tão diverso, heterogêneo e complexo como o sistema natural. Sabe-se que o elemento central da análise da Economia Neoclássica é a preferência individual, expressa em termos monetários, cuja maximização determina as soluções "ótimas" de equilíbrio dos mercados. Para os neoclássicos, o mercado é capaz de alocar eficientemente os recursos naturais. Quando um elemento do capital natural é transacionado no mercado, concomitantemente lhe é assinalado um valor, um preço, mas, no caso dos elementos para as quais não existem mercados, os valores podem ser estimados por outros métodos e técnicas (Amazonas, s.d.; Prugh, 1995, Casimiro Filho, 1998).

O sistema de preço é considerado limitado para refletir o verdadeiro valor do estoque de capital natural, devido a vários fatores. Os preços não podem expressar a disponibilidade do recurso, dado que estoques de capital natural não estão totalmente inventariados; eles ignoram as funções ecossistêmicas que estão á margem do processo econômico, mas que são ecologicamente essenciais, e o nível de degradação ambiental. Ademais, a heterogêneidade intrínseca ao capital natural também torna sua valoração monetária e indicadores incapazes de captarem adequadamente as restrições ambientais enfrentadas pela sociedade, no exercício de suas atividades econômicas. Por todos esses fatores, “... o valor econômico do recurso natural realizado no mercado geralmente representa uma subestimativa do seu custo de oportunidade social..." (Motta 1997, p.7). Neste sentido, Casimiro Filho (1998) acrescenta: 
"O meio ambiente oferece à sociedade diversos tipos de benefícios. Alguns podem ser valorados com relativa facilidade por possuírem preços de mercado. Este é o caso da produção de alimentos, madeira, minerais etc. Outros como recreação/turismo, biodiversidade, processos ecológicos, educação, pesquisa, etc. por não possuírem preços de mercado, são difíceis de serem mensurados monetariamente. Essa dificuldade em estabelecer valores para o meio ambiente está associada às características dos bens $\mathrm{e}$ serviços que o compõe. Muitas destas características geram falhas no funcionamento eficiente dos mercados" (Casimiro Filho 1998, p.1).

“... Em se tratando de recursos naturais e/ou ambientais, em geral, os mercados não são capazes de atingir a eficiência de mercado $^{29}$, ou seja, eles não racionam os recursos entre os consumidores e não fornecem informações corretas sobre a escassez relativa dos mesmos" (Casimiro Filho 1998, p.17).

Com isso, não se pode afirmar que necessariamente aquele "ótimo" mercadológico corresponda ao "sustentável". O importante é que inúmeros economistas ambientais, de inspiração neoclássica ou não, têm construído e aprimorado técnicas para valoração de bens e serviços ambientais. Nessa direção, procuram-se desenvolver modelos que analisem os aspectos relativos aos limites naturais impostos à atividade econômica, reconhecendo a importância não só das condições essencialmente presentes no meio ambiente, mas incluindo critérios éticos sociais, institucionais etc. que determinam o nível do desenvolvimento sustentável (Lima, 1999; Amazonas, s.d.).

${ }^{29}$ A não-exclusividade, não-rivalidade e congestionamento são as falhas no funcionamento do mercado de recursos naturais e/ou ambientais, relacionadas por Casimiro Filho (1998). 


\section{Categorias de valor do capital natural ${ }^{30}$}

Com relação à valoração do capital natural, a forma mais simples de classificá-lo obedece a três categorias de valor: uso, opção e existência, os quais compõem o valor econômico total do meio ambiente. O "valor de uso" é aquele estabelecido por meio do consumo de produtos do capital natural. Esse consumo pode ser estabelecidos no mercado (mercado-capturado ou valor de uso produtivo), como o consumo de árvores adquiridas para insumo da construção civil e registrado nos sistemas de contabilidade das nações. $O$ consumo também pode se dar fora do mercado (mercado-ignorado ou valor de uso de consumo), como a vida selvagem, e não é refletida na Contabilidade Nacional.

O "valor de opção" geralmente se refere ao valor de uso potencial do capital natural e não só seu valor de uso presente. A idéia está atrelada ao controle da preservação do capital natural para o uso futuro e, nesse sentido, diz respeito à disposição a pagar para conservar um determinado recurso. Já o "valor de existência" envolve o senso de simpatia das pessoas por determinado recurso mesmo quando não têm contato direto com ele, mas apenas o conhece por intermédio de propagandas, comentários de amigos etc. Nesse caso, a informação sobre existência do recurso natural, mesmo sem intensão de utilizálo, já traz benefícios aos indivíduos.

\section{O Método Valoração Contingencial (MVC) e o Método do Custo de Viagem (MCV)}

Os métodos apresentados anteriormente não são os únicos desenvolvidos; existem outras técnicas que procuram estimar valores nãomercantilizados do capital natural, os quais utilizam uma abordagem direta e indireta, denominada, respectivamente, Método de Valoração Contingencial

\footnotetext{
${ }^{30}$ Ver Prugh (1995) e Casimiro Filho (1998).
} 
(MVC) e o Método do Custo de Viagem (MCV), os dois mais conhecidos. O MVC procura registrar informações referentes ao valor de uso, ao valor de opção e ao valor de existência ao questionar as pessoas qual seria a disposição delas para pagar ao utilizarem as amenidades no presente ou na possibilidade de uso futuro, ou, ainda, para simplesmente garantir sua existência (Prugh, 1995; Casimiro Filho, 1998).

O MCV procurar estimar os custos incorridos pelos indivíduos, quando usufruem de um determinado local de recreação. Muitas vezes, a pessoa não paga determinado preço pelos recursos naturais utilizados, então o MCV surge como uma alternativa ou substituto do preço do bem ou serviço que é explorado pela referida atividade. Geralmente, esse método coleta informações sobre custos de viagem, taxa de visitação, características sócioeconômicas etc. Segundo Casimiro Filho (1998), "A partir desses dados, estima-se a curva de demanda e o excedente do consumidor. Este último representa uma estimativa do valor econômico do local em questão" (Casimiro Filho 1998, p.27).

\section{Estimativa do Valor Presente Líquido (VPL), através do Preço Líquido (PL) e do Custo de Uso}

Sobre um estoque de capital natural, pode-se deduzir seu valor presente líquido (VPL), que corresponde à soma de todos os lucros futuros derivados dele. Existem dois métodos conhecidos para estimar o VPL de um estoque de recurso. O primeiro, o método do "Preço Líquido" (PL), trata da depleção como se fosse uma depreciação do capital, e, desse modo, deduz de uma renda bruta o valor total dos recursos extraídos. A PL somente requer informações sobre os níveis de extração anual. Assim, o PL mede a redução líquida dos recursos naturais além de sua capacidade regenerativa. É uma avaliação direta, que pode ser conectada diretamente às mudanças físicas no capital natural (Torras, 2000; Abaza, 1992). 
A abordagem de "custo-uso" ou método para avaliar o "custo de compensação pelo uso" é baseado da noção de investir porção da renda recebida do uso e depleção de um recurso, a fim de generalizar um fluxo permanente de renda, ou seja, este reflete a necessidade de reinvestir parte da renda ganha com a exploração do meio ambiente. Esses cálculos utilizam o tamanho dos estoques de recursos (em termos de toneladas, metros cúbicos, e outras), cujas informações são dadas por inventários freqüentemente superficiais (Torras, 2000; Abaza, 1992).

Variações quantitativas e, ou, qualitativas dos recursos naturais também podem ser medidas como o caso da extensão da erosão do solo. Esta pode ser estimada por dois métodos: através da perda de produtividade agrícola ou das perdas das propriedades físicas e biológicas deste recurso. A primeira abordagem requer um montante grande e variado de informações e dados, como perdas físico-biológicas do solo, relação entre erosão e produtividade para cada tipo de solo, trabalho e maquinaria requeridas, nível de produção, custos e preços através do tempo para uma variedade de safras. A segunda abordagem é conhecida como custo de reposição e é menos complexa empiricamente. $O$ valor de perda associado com a erosão é estimado da expansão do volume de fertilizantes químicos requeridos para suprir o solo com nutrientes (nitrogênio, fósforo e potássio). Também, a perda econômica atribuída à erosão do solo é estimada a por este método (Torras, 2000).

\section{Capital natural e o Sistemas de Contas Nacionais (SCN)}

No agregado, a relação capital natural e desempenho econômico é de difícil mensuração. Isso é verificado principalmente quando se observa o tipo de tratamento que o Sistema de Contas Nacionais (SNA) outorga às variações ocorridas nos estoques dos recursos naturais para as estimativas do Produto Nacional Bruto (PNB), uma das mais importantes estatísticas econômicas. As contas nacionais falham ao descrever mudanças na qualidade e quantidade do 
estoque do capital ("tradicional") de forma diferente do tratamento dado ao capital natural. Manufaturas e maquinarias são consideradas como capital produtivo e quando utilizados ou danificados, são tratados como consumo, sendo o valor da perda subtraído do PNB. Com relação ao capital natural, as contas não mostram explicitamente o valor dos serviços proporcionados pelo ecossistema e o valor dos gastos com defensivos utilizados contra a poluição, nem refletem o valor dos serviços não-comercializáveis, como recreação em terras públicas. Geralmente, o consumo de capital natural é tratado como renda, fazendo com que o SCN superestime o produto ou renda nacional (Prugh, 1995).

“... À medida que os recursos de capital natural possuem algum valor econômico (um ponto contestável), eles são uma forma de capital por definição, a despeito de não estar sendo produzido, como é o capital manufaturado. Renda sustentável (ou PIB verde) deveria por isto ser definido como um fluxo máximo que permite o valor agregado de estoque de capital manufaturado e capital natural serem preservados" (Torras 2000, p.355).

Diante dessas deficiências, instituições como as Nações Unidas têm produzido esforços para planejar um sistema de contabilidade que melhor assegure $\mathrm{o}$ valor de capital natural. Pesquisas têm sido constantemente realizadas para incorporar mais informações sobre recursos naturais e ambientais dentro da contabilidade nacional e informações sobre custos advindos da depreciação, de gastos com o controle da poluição e o valor monetário da degradação ambiental (Prugh, 1995). Segundo Fenech et al. (1999):

"... Riqueza é definida como o gerenciamento de bens relacionados numa dada nação. Os bens incluem: infra- 
estrutura de construção, recursos naturais (minerais, energia, terras agrícolas, florestas), capital humano e capital social. Expandindo a noção de riqueza implica em incluir estes diferentes tipos de riqueza na contabilidade dos bens da nação" (Fenech et al.1999, p.2).

\section{Sistema Integrado de Contabilidade Econômica e Ambiental (SICEA) ${ }^{31}$}

Tendo em vista o aprimoramento do SCN para a estimativa exata do montante da riqueza nacional, a Divisão Estatística das Nações Unidas apresenta o Sistema de Contabilidade Econômica e Ambiental Integrado (SICEA), que, resumidamente, tem os seguintes objetivos:

- identificar os gastos com a proteção ambiental;

- prover um sistema de dados que permita articular a contabilidade de recursos físicos com a contabilidade ambiental monetária;

- avaliar a depleção de recursos naturais e o nível de poluição (emissões);

- contabilizar para a manutenção da riqueza tangível; e

- calcular indicadores ambientalmente-ajustados. A depleção dos recursos foi estimada utilizando um método similar ao métodos de depreciação do capital físico, para ser deduzida do PNB, e, dessa forma, obter um "Produto Nacional Ambientalmente-Ajustado" (PNA).

\footnotetext{
${ }^{31}$ Este sistema foi apresentado ao Committee of International Development Institutions on the Environment (CIDIE): Workshop on Environmental and Natural Resource Accounting.
} 
Em 1991, a "Associação Internacional Especial", que pesquisa sobre "Renda e Riqueza", tem visto a necessidade de separar a depleção do recurso da depreciação ambiental nos trabalhos realizados. Por esta razão, a SICEA tem calculado duas medidas do "Produto Nacional Líquido AmbientalmenteAjustado" (PNLA). A primeira medida, o EDP1, é ajustado pela depleção dos recursos e a segunda, o EDP2, é ajustado pela degradação ambiental (Abaza, 1992).

Mesmo com as inovações mencionadas o SICEA é considerado conservador. O sistema apenas relacionou atividades ambientais intimamente conectadas ao sistema econômico e não incorporou os aspectos saúde, ética e estética, por exemplo. Também, não contabilizou as transformações que ocorrem apenas dentro do ambiente natural. No entanto, observa-se que a SICEA procurou calcular um indicador de crescimento econômico sustentável e vem trabalhando as limitações e restrições do SCN, fazendo conjecturas para vincular a contabilidade de recursos físicos com estatísticas ambientais (Abaza, 1992).

\section{Modelo de crescimento econômico incluindo o capital natural}

A despeito de trabalhos anteriores, nos últimos anos pesquisadores tem incorporado nos modelos econômicos as inovações teóricas, metodológicas e técnicas sobre o capital natural, anteriormente referidas. Os modelos de crescimento econômico da década de 70 apresentavam hipóteses fracas sobre a essencialidade dos recursos e seus impactos no nível de crescimento da economia. Apoiavam-se numa elasticidade de substituição superior ou igual a 1 e justificavam que bastaria reinvestir parte da renda gerada com a exploração de recursos naturais na formação de capital, seja material, seja natural, e manter o estoque de capital constante, que a maximização do bem-estar seria alcançada. Assim, as questões ambientais não eram consideradas relevantes ou restritivas ao crescimento sustentável, que 
seria alcançável pela capacidade de evitar que a receita gerada na exploração do recurso natural seja transformada em consumo presente (Motta, 1997).

"Obviamente esta abordagem, por vezes rotulada na literatura como neo-clássica, carece de realismo sobre a produtividade dos sistemas naturais. A capacidade de geração de serviços dos ecossistemas depende da manutenção de certos componentes ecossistêmicos, tais como, população e cadeia alimentar, dentro de limites específicos. Uma vez vencidos estes limites o sistema poderá entrar em colapso e sua produtividade torna-se nula. A definição destes limites identifica os limites do crescimento e, portanto, determina a trajetória de sustentabilidade de uma economia ... Assim, é prudente identificar quais os níveis mínimos de segurança ou a capacidade de suporte dos recursos naturais que estão sendo apropriados na geração de renda (Motta 1997, p.5).

"As condições essenciais para realizar estas iniciativas são: a) a criação de um sistema estatístico ambiental que defina tais indicadores e b) o estabelecimento de relações destes com os tradicionais indicadores econômicos e sociais..." (Motta 1997, p.18).

Recentemente alguns modelos de crescimento econômico procuram refletir exatamente a base física e ecológica de atividade econômica que identifique o feedback entre a economia e o meio-ambiente. Neste sentido, mais recentemente, tem-se desenvolvido novos modelos, denominados "Modelos de Crescimento Econômico-Ecológico", que insere capital natural, mão-de-obra e capital manufaturado. Nesses modelos são propostas uma revisão e uma estrutura alternativa, numa abordagem que identifica o grau de degradação 
ambiental e contabiliza todos os serviços oferecidos pelo meio ambiente (England, 1998; Ayres et al., 1996).

Os novos modelos de crescimento contabilizam 0 ambiente focalizado sobre capital natural não-renovável e bens do ecossistemas como madeira, água, praias etc. Incorporam ecossistemas e seus serviços que foram largamente ignorados, uma grave omissão, dado o aspecto único, insubstituível destes na produção econômica (Ayres et al. 1996).

“... Capital natural captura energia solar e comporta um sistema autônomo complexo. Bens e serviços ecológicos e amenidades são produzidos, e eles contribuem de diferentes modos para satisfazer as necessidades básicas humanas e criar ambos bem-estar do indivíduo e da comunidade..." (Ayres et al. 1996. p.12).

O "Modelo de Crescimento Econômico-Ecológico" não é uma simples elaboração ou refinamento de modelos-padrão de crescimento. Ele fundamentalmente altera a relação entre os capitais e modifica as hipóteses básicas sobre o papel da produção em adequar desejo e necessidades humanas e avaliar o potencial de crescimento sustentável (Ayres et al. 1996).

"... Um modelo de crescimento revisado pode responder as seguintes questões: (1) em que grau pode a depleção dos recursos limitar o crescimento; (2) em que grau pode a capacidade ambiental promover desgaste no limite do crescimento... Os modelos de crescimento devem contabilizar a acumulação de perdas do capital natural e seu feedback negativo sobre a renda econômica, no tempo e espaço. A acumulação de perdas materiais pode reduzir a produtividade de capital natural..." (Ayres et al. 1996, p.13 e 14) 


\section{Modelo de renda econômica com inclusão do capital natural ${ }^{32}$}

Atentos à questão da "sustentabilidade" Figueroa \& Calfucura (2002) desenvolvem um modelo de renda econômico. Esses pesquisadores supõem uma economia aberta que possui estoques de recursos naturais diferenciados em renováveis e não renováveis, maximizadores do bem-estar em um horizonte infinito de tempo. Esse modelo assume que o fator trabalho é fixo e não existe progresso tecnológico.

Vários indicadores econômicos e ecológicos, ou indicadores econômicos ambientalmente ajustados, são estimados. O Produto Nacional Líquido (PNL) é corrigido pela perda de capital natural, depreciação líquida dos recursos renováveis, custo de extração dos recursos minerais, incorporando a contaminação e incremento das reservas minerais; calculou-se a Poupança Nacional Natural (PNN) proposta por Pearce \& Atkinson (P\&A) em 1993. Esse indicador é estimado da seguinte forma: da Poupança Nacional Bruta (PNB) são subtraídos o consumo de capital físico, o valor de extração dos recursos não-renováveis e o custo social da contaminação, dentre outros fatores relacionados. Se PNN for menor que zero (0), significa que o investimento líquido da economia seria decrescente e o crescimento, não-sustentável.

Para a valoração dos recursos renováveis e não-renováveis, o enfoque de valoração mais usado em trabalhos empíricos sobre contabilidade ambiental tem sido o "Preço Liquido" (PL). Resumidamente, o preço líquido do ativo é igual ao preço efetivo de mercado do recurso menos os custos efetivos de exploração (que incluem uma taxa normal de retorno ao investimento). Dadas as dificuldades de estimação dos custos marginais, geralmente se supõe equilíbrio de longo prazo, em que os custos marginais são iguais aos custos médios.

\footnotetext{
32 Todas as fórmulas e mais detalhes sobre estas discussões ver Figueroa \& Calfucura (2002).
} 
Enfim, verifica-se que os trabalhos mais recentes têm sublinhado a necessidade da geração e aperfeiçoamento das concepções, métodos e indicadores que norteiam as políticas e ações rumo ao desenvolvimento sustentável com garantia não só da qualidade de vida, bem-estar e progresso econômico, mas também como uma questão de sobrevivência humana ao longo de várias gerações.

\subsection{Revisão de alguns estudos empíricos relevantes}

\subsubsection{Análise da estrutura da industria turística: estudo de casos}

Objetivando fundamentar a análise da estrutura da industria turística de Ilhéus, neste capítulo apresenta alguns trabalhos realizados em âmbitos internacional, nacional e regional, respectivamente. As obras são citadas por considerarem variáveis e aspectos metodológicos semelhantes aos abordados por neste estudo. Tais referências dão o suporte necessário ao encaminhamento desta pesquisa, às interpretações dos dados coletados e aos resultados encontrados.

\subsubsection{De trabalhos realizados em outros países}

Algumas técnicas e métodos de avaliação utilizados nos trabalhos realizados em várias partes do mundo revelam os determinantes do desempenho da atividade turística de cada localidade. Na África do Sul, a incapacidade local de aproveitamento de todo potencial existente é destacado como um dos principais gargalos do turismo regional. Segundo Muller (1998), a criação de postos de trabalho e o crescimento econômico local apresentam-se limitados, situação que só será reversível quando a qualidade dos serviços e produtos ofertados forem ampliados. Destaca que na África do Sul o turismo poderia criar mais de 500 mil novos empregos, ao longo de 12 anos, e alcançaria eficiência em relação à exploração do potencial, mas somente se as fragilidades existentes forem corrigidas. 
No que diz respeito à avaliação do turismo, esta pode ser realizada pelos moradores ou através dos próprios visitantes. No estudo sobre o Dakota do Norte, Schroeder (1996) considera a imagem dos próprios residentes um perfeito indicador das deficiências locais e, por isso, suporte essencial para o bom desenvolvimento da atividade. A população local pode direcionar as políticas ao avaliar, precisamente, diversos aspectos que determinam o nível de qualificação da indústria turística. Além disso, os residentes podem influenciar a imagem do visitante potencial, via informações cedidas aos amigos, parentes etc., o que certamente impacta o fluxo de visitantes.

$\mathrm{Na}$ pesquisa de Schroeder (1996), solicitou-se aos entrevistados a avaliação de 20 atributos de Dakota do Norte, segundo a escala Likert, no intervalo entre 1 (péssimo) e 7 (excelente). Em média, as variáveis "limpeza/meio ambiente" $(6,12)$ e "pessoas amigas" $(5,97)$ registraram as maiores notas. No entanto, os menores valores médios foram obtidos para os atributos "montanhas/florestas" $(2,54)$ e "praias" $(1,98)$. Utilizou-se a análise fatorial para identificar os componentes principais da imagem de Dakota do Norte como destino turístico, objetivando eliminar toda correlação entre os atributos. A rotação varimax, selecionou quatro fatores que descrevem essa imagem. O primeiro, o "Fator turismo" relacionou as variáveis "montanhas e florestas", "parques nacionais" e "áreas pitorescas", "culturas diferentes", "museus/lugares históricos" e "vida selvagem". O segundo, o "Fator urbano", agregou as variáveis "shopping", "restaurantes finos", "entretenimento noturno", "resorts luxuosos" e "cidade turística". O terceiro, o "Fator atividade-orientada", compreendeu "caça", "pesca", "esportes de inverno", "tênis/golf" e "camping". E por fim, o quarto, o "Fator hospitalidade", relacionou "limpeza" e "meio ambiente", "pessoas amigas" e "preços moderados das acomodações".

Schroeder (1996) ainda indagou aos residentes: "De que forma você recomenda de Dakota do Norte como um lugar para visita?". Do total entrevistado, $75 \%$ responderam que consideram o local "muito apropriado", 
$24 \%$ consideraram "pouco apropriado", e apenas 1\% classificaram como "nãoapropriado". Entretanto, levando em conta a quantidade de variáveis envolvidas, modelos e testes realizados, neste trabalho apresentou-se muito resumido e incapaz de esclarecer completamente o processo realizado para o alcance de todos os resultados encontrados.

Estudo semelhante ao de Schroeder (1996) foi efetuado por Andereck \& Vogt (2000), que avaliaram a postura/posição dos residentes como indicativo para o desenvolvimento de opções turísticas específicas. Foram pesquisadas sete comunidades diferentes, que representam o meio rural, pequenos locais urbanos e reservas naturais americanas. Estas não foram aleatoriamente selecionadas, mas representam a distribuição geográfica da área, a diversidade econômica e a etnia dos residentes da região. O questionário incluiu, dentre outras, a seguinte questão: "aceitabilidade das opções do desenvolvimento turístico específico", avaliada numa escala de cinco (5) pontos, que variou da condição de "não-aceitabilidade" (1) a "extremamente aceitável" (5). Ademais, a posição dos residentes sobre o turismo foi medida através de 41 atitudes (específicas e gerais) da comunidade, declaradas utilizando cinco pontos na escala, variando de "extremamente divergente" (1) à "extremamente de acordo" (5). O referido autor descreve minuciosamente as várias etapas realizadas para a conclusão da pesquisa no que diz respeito a elaboração do questionário, definição do tamanho da amostra, escolha dos entrevistados e formas de abordagem dos mesmos; além disso, através da vasta revisão de literatura, o trabalho mostrase fortemente fundamentado.

Desconsiderando os resultados segundo as diferentes comunidades pesquisadas, seguem as conclusões gerais do trabalho realizado por Andereck \& Vogt (2000). Das notas médias calculadas, o "desenvolvimento de jogos" $(2,88)$ e "bares/clubes" $(2,46)$ "não foram aceitáveis" para a maioria dos questionados. As atrações como "parques" $(3,97)$ e "oportunidades de 
recreação ao ar livre" (3,95), foram as opções "mais aceitas". "Atrações históricas/culturais" $(3,87)$, "eventos especiais" $(3,84)$ e "museus" $(3,65)$ foram "altamente aceitáveis". "Serviços dos restaurantes" $(3,82)$, "vendas a varejo" $(3,80)$, "alojamento" $(3,48)$ e "transporte público" $(3,47)$ foram considerados "aceitáveis".

Posteriormente, os 41 itens, antes referidos no trabalho de Andereck \& Vogt (2000), foram reduzidos pela análise fatorial, via método dos componentes principais e rotação varimax, e três fatores foram extraídos: "Fator 1 - desenvolvimento da comunidade", "Fator 2 - qualidade de vida" e "Fator 3 - impactos negativos", com médias 3,88; 3,67; e 2,78, respectivamente. Além desses resultados, calcularam-se as correlações entre as opções dos produtos e estimou-se a regressão da relação "atitudes dos nativos" como indicador para o desenvolvimento turístico. Ao comparar várias comunidades rurais, resultados diferenciados foram encontrados, mas, no geral, os residentes têm percebido positivamente o turismo e apoiam os tipos específicos de desenvolvimento desta atividade.

Os visitantes também podem auxiliarem no processo de avaliação do turismo. Por isso, Luzar et al.(1998) procuraram identificar os fatores que influenciam a decisão do visitante potencial em participar da atividade turística de Louisiana, USA. Esses pesquisadores utilizaram o Modelo Logit Multinomial, espécie de Modelo Logit Binário, aplicado para decisões que envolvam mais que duas escolhas. Os dados para a análise empírica foram obtidos do turista potencial de Louisiana, por levantamento, via correspondência. A decisão de participação no turismo de Louisiana foi hipotetizada como função de fatores sócioeconômicos, físico-geográficos etc. O grupo de variáveis explanatórias tentaram capturar/apreender os elementos cruciais como a capacidade financeira (renda) e outras características do indivíduo, informações sobre ecoturismo e categorias que avaliam as atividades de recreação. Na maior parte do questionário, as respostas dos entrevistados foram classificadas de 
acordo as seguintes opções: "concorda plenamente" (5), "concorda" (4), "não opina" (3), "descordo" (2), "plenamente em desacordo" (1). Outros detalhes da pesquisa e especificamente da coleta de dados foram delimitados pelo pesquisador. O principal modelo proposto pode ser escrito sobre a seguinte forma geral:

Turismo $=f($ renda, minoria, gênero, $N E P$, estado, família, $\in)$

em que a variável Turismo assume o valor zero se o indivíduo decidir "não viajar", 1 se a pessoa "pretender viajar, mas não participar do turismo verde", e 2 se o entrevistado "pretende viajar e participar do turismo verde". A variável renda corresponde à renda anual do indivíduo, que assume valor 1 para renda maior que US\$50.000, zero se for o contrário. A variável minoria está relacionada à raça do entrevistado que assume valor 1 se "raça minoritária" e zero se for o contrário. gênero diz respeito ao sexo da pessoa, 1 se feminino, e zero se "masculino". NEP é o indicador novo paradigma ecológico, que mede a atitude ambientalista. A variável estado refere-se ao estado de origem do entrevistado que assume valor 1 se distante de Louisiana e zero se for o contrário. família quantifica os familiares do indivíduo e $\in$ é o termo erro.

Os resultados empíricos apresentados por Luzar et al. (1998) indicam que a partir de um relativo aumento de renda o turista tem mais probabilidade de participar do turismo verde internacional do que do turismo verde de Louisiana. Isso é explicado pela maior diversidade de oportunidades de viagens dos indivíduos que dispõem de maiores rendas. A probabilidade de comprometer-se com o ecoturismo de Louisiana foi de 20,9\% maior para indivíduos com renda anual menor que US\$50.000, dadas as razões já salientadas. Houve uma significativa associação negativa entre o tamanho da família do indivíduo e a decisão de visitar Louisiana. Aumento no tamanho da família produziu uma variação marginal negativa na probabilidade de participação no ecoturismo. O resultado empírico ainda evidenciou que um 
aumento no escores do $N E P$ resulta em 0,027 de aumento na probabilidade de comprometer-se com o turismo natural. Portanto, mudanças nas atitudes ambientalistas resultam numa mudança marginal positiva e significativa na probabilidade de comprometer-se no turismo verde. O mesmo ocorre em relação à proximidade; esse fator influencia positivamente a decisão de participar do ecoturismo de Louisiana.

Kozak \& Rimmington (2000) procuram avaliar a relação atributos turísticos e o nível de satisfação total do visitante de Mallorca (Espanha), durante o período de inverno. Dentre outros objetivos, neste estudo se pretendeu o seguinte: identificar os elementos do destino que os turistas mais gostaram e os que eles não gostaram e determinar a contribuição de cada um destes na satisfação total, na probabilidade de repetir a visita e de recomendála a outras pessoas. Revelam que percepções sobre as facilidades obtidas, atrações e serviços padronizados são influenciadas por comparações com diversos locais percorridos pelo visitante. Este estudo ainda pontua outros trabalhos $^{33}$ que relacionam a satisfação do visitante com o serviço de guias, visitas culturais, satisfação com hotéis, restaurantes, nativos, disponibilidades de lazer e recreação. Os aspectos diferenças culturais e de classe social também são examinados. Ademais, demonstram que a satisfação do visitante, transmitida por este a outras pessoas de seu contato, constitui importante fonte de vantagens competitivas. Os autores consideram que a percepção do turista é importante para o sucesso do "marketing" de um destino, pois influencia a escolha de um local e a decisão de retorno.

Kozak \& Rimmington (2000) argumentam que não há consenso de como ou quando medir a satisfação do consumidor; no entanto, a literatura alerta para o fato de que a satisfação é uma função, em geral, avaliada após a compra, devendo ser estimada após a concretização desta. Descrevem que as

${ }^{33}$ Toda a discussão apresentada por Kozak \& Rimmington (2000) é fundamentada em trabalhos empíricos realizados por outros pesquisadores. 
escalas tipo Likert ou escalas de diferencial semântico podem ser empregadas com o propósito de avaliar experiências turísticas nas áreas de destino, porque elas efetivamente medem a satisfação dos consumidores e são de fácil construção e condução ${ }^{34}$. Esses pesquisadores aplicaram um questionário que foi estruturado em três seções. Na primeira, detalhes básicos sobre o turista e suas férias foram obtidos. A segunda, composta de 38 itens baseadas numa escala de 7 pontos, foi estruturada para mensurar o nível de satisfação do turista. Salvo exceções, de forma geral, as opções de respostas das diversas questões seguiu a seguinte escala: "não conhece" (0), "horrível" (1), "descontente" (2), "muito insatisfeito" (3), "pouco satisfeito ou não satisfeito" (4), "satisfeito" (5), "muito satisfeito" (6) e "encantado" (7). Da terceira seção, ao interrogar sobre a probabilidade do turista retornar no futuro e recomendar a outros, a escala variou de "recomendaria (com certeza)" a "não recomendaria (de maneira nenhuma)". Outros vários detalhes metodológicos, sobre a forma de aplicação dos questionários e dados coletados foram detalhados pelos autores.

Kozak \& Rimmington (2000) utilizaram o Statistical Package for the Social Sciences (SPSS) para analisar os dados coletados e apresentaram os resultados da análise fatorial dos 38 atributos mensurados. Para identificar os fatores, o método dos componentes principais, via rotação varimax, foi empregado considerando eigenvalue 1 ou maior que $1(>1)$. O Teste Bartllet's, de esfericidade, com o valor de 5150.81 e o cálculo estatístico de KaiserMeyer-Olkin de 0.92 indicam que os dados são adequados para a análise fatorial. Variáveis com cargas iguais ou maiores que 0.45 foram incluídas em um determinado fator. Um total 30 itens de satisfação foram agrupados em quatro fatores os quais explicam $71,1 \%$ da variância das variáveis. A maioria

34 ECHTNER, C. M.; RITCHIE, J. R. B. The meaning and measurement of destination image. Journal of Tourism Studies, v.2, n.2, p.2-12, 1991. 
das cargas fatoriais foi superior a 0.60 , indicando a boa correlação entre os itens agrupados e os respectivos fatores. Os coeficientes variaram entre 0.90 (fator 4) e 0.94 (fator 1), indicando que as variáveis foram consideradas consistentes internamente.

Kozak \& Rimmington (2000) rotularam os fatores. O "fator 1 Atrativos do destino" explicou 55\% da variância do modelo e agregou 11 itens: o "padrão de qualidade das acomodações", o "nível dos serviços das acomodações", opinião sobre "segurança", "atitudes do pessoal empregado na atividade turística", "meio ambiente", "qualidade e variedade dos alimentos", "limpeza das praias", "higiene e saneamento geral". O "fator 2 - Atrações e facilidades turísticas" explicou $7 \%$ da variância do modelo e foi composto por oito itens: a "disponibilidade de esportes", "disponibilidade de vida noturna", "entretenimento", "praias", "museus", "lugares históricos" e "variedade de atrações". O "fator 3 - A prática da língua inglesa", responsável por $5 \%$ da variância do modelo, agregou seis itens relacionados ao nível de comunicação, como a "disponibilidade de material escrito nos cardápios dos restaurantes", nos " 'menus' das acomodações", nas "sinalização nos aeroportos" etc., todos escritos em inglês. O "fator 4 - Os serviços do aeroporto" explicou 4\% da variância e foi composto por 5 itens: "limpeza", "rapidez na entrada e saída" no mesmo, "existência de aeroportos" e "distância e conforto da viagem entre os resorts e os aeroportos". As médias dos escores dos fatores indicam que o mais satisfatório foi o fator $4(5,03)$ e, o menos satisfatório, o fator $2(4,56)$. Os referidos autores consideram que o período de temporada influenciou as respostas e, conseqüentemente, os resultados. A menor satisfação atribuída ao fator 2, provavelmente se deva à restrição de "atrações e facilidades turísticas" durante o inverno. No entanto, o novo aeroporto, muito melhor que o antigo, teve interferência na avaliação positiva do "fator 4 - Serviços dos aeroportos".

Kozak \& Rimmington (2000), através da análise de regressão e do modelo Lógite, procuraram observar a relação entre variáveis. As variáveis 
dependentes desses modelos foram o nível de satisfação total, a intenção em visitar novamente e a intenção de recomendar para outras pessoas. As variáveis independentes foram as seguintes: os quatro fatores extraídos, as experiências anteriores e o nível de satisfação total. A razão para o uso dos escores fatoriais foi evitar o efeito da multicolinearidade no modelo e a possibilidade de alta correlação entre as variáveis.

Kozak \& Rimmington (2000) apresentam a influência dos quatro fatores no nível de satisfação total dos entrevistados. As estimativas-padrão (coeficientes beta) de cada fator refletem a importância relativa desses no modelo. Quanto maior a estimativa, mais importante o fator no modelo. Foi observado que apenas três fatores/variáveis independentes apresentaram coeficientes beta estatisticamente significantes $(p<0.001)$ : fator $1(\beta=0.51)$, fator 2 ( $\beta=0.32$ ) e fator 4 ( $\beta=0.21$ ). O fator 3 não exerceu impacto no nível de satisfação dos turistas britânicos $(p>0.05)$. No mais, esses pesquisadores consideram a possibilidade de que os níveis de satisfação sejam diferentes desses durante o período de alta estação.

Das intenções dos turistas britânicos em voltar a Mallorca, o fator 1 ( $\beta=0.27)$, o fator $4(\beta=0.18)$, o nível de satisfação total $(\beta=0.26)$ e as experiências anteriores dos turistas $(\beta=0.17)$ apresentaram-se como fortes determinantes no trabalho de Kozak \& Rimmington (2000). Isso significa que a probabilidade de retorno deve ser aumentada significativamente quando os turistas estão satisfeitos com aqueles dois variáveis-fatores e obtiveram um bom nível de satisfação (total) com o destino. Entretanto, o fator 2 e o fator 3 não aparecem como incentivos de visita repetida. Da intenção dos turistas em recomendar Mallorca para outras pessoas, o resultado revela que o fator 1 ( $\beta=0.37)$ tem grande impacto $(p<0.001)$, já o fator 2 e a experiência anterior dos turistas com a área de destino não mostrou-se significativa $(p>0.05)$ para 
explicar sua relação com a intenção de recomendar a conhecidos, parentes e amigos.

Segundo Kozak \& Rimmington (2000) o "Coeficiente de Correlação de Pearson" evidencia que a relação entre satisfação total do turista e sua intenção de voltar a visitar $(r=0.6044, p<0.001)$ e entre a satisfação total dos turistas e a intenção de recomendar a outros ( $r=0.6927, p<0.001)$ foram muito fortes. A significativa correlação entre a intenção de recomendar e a intenção de voltar a visitar $(r=0.7253, p<0.001)$ evidenciou que o turista que recomenda uma visita tem a intenção de visitar novamente, ou seja, no caso de Mallorca, quanto mais os turistas estão satisfeitos, mais eles retornarão e recomendarão a outros. Entretanto, o fator 2, mesmo representando o segundo mais importante fator determinante do nível de satisfação total, apresentou-se insignificante na intenção de revisita e de recomendação a outras pessoas. Isso evidencia que alguns atributos podem ser importantes para a satisfação total, mas pode não representar elementos que sustentem visitas repetidas e estimulem positiva comunicação "boca a boca".

\subsubsection{De trabalhos realizados no Brasil}

A despeito do crescimento do turismo brasileiro, algumas pesquisas alertam sobre as fragilidades do setor, observando que os impactos gerados dependem do nível de exploração do potencial nacional, em termos de atrativos. Sem dúvida, o turismo é uma atividade motriz, mas, no Brasil, os ganhos manifestam-se de forma muito diferenciada. É preciso estar atento para o fato de que o impacto depende das características de cada local, das précondições naturais e econômicas e do "papel" reservado ao turismo nas estratégias políticas para o desenvolvimento, definidas também a partir da comunidade local, tornando-se fundamental a integração intersetorial na escolha de ações que tragam benefícios amplos (Rabahy, 1990). Nesse sentido, Arley (1999) examina a evolução do turismo da cidade histórica de 
Ouro Preto, MG, entre 1897-1973, e destaca a importância da construção social para o sucesso da atividade local. Ele frisa que, após os anos 50 , foram as representações sociais do município que promoveram e possibilitaram o resgate, no tempo e no espaço, das obras e monumentos históricos, contextualizando e estabelecendo o produto turístico a ser ofertado por aquele município.

Sobre Ilhéus, na Bahia, pesquisadores tem avaliado a estrutura do turismo não por meio de modelos e técnicas avançadas, mas descrevendo as características e o desempenho da atividade de forma minuciosa. Queiroz (1993a), por exemplo, resgatou o histórico da constituição do turismo ilheense inter-relacionando-o com o perfil atual e perspectivas do setor. Utilizou o método exploratório descritivo, cruzando informações qualitativas, das pesquisas primárias, com os indicadores estatísticos, obtidos nos organismos regionais de turismo. Segundo aquela autora, Ilhéus despontou como centro comercial e no turismo de negócios (no auge da produção cacaueira), posteriormente evoluindo para o turismo de lazer (como alternativa à crise do cacau).

Foi a difusão dos romances de Jorge Amado na Europa, a partir dos anos 80 , que atraiu novos capitais internacionais formadores de grande parte do núcleo turístico regional atual. Sobre a composição dos equipamentos existentes em llhéus, a indústria turística seguiu o modelo implementado por seus investidores pioneiros de diversas regiões e estados. Primeiramente, predominou as agências de viagens exportativas, e logo após ampliou-se o número de agências receptivas. A rede hoteleira é caracterizada pela tendência ao padrão de alto luxo, no estilo resort; em 1992; dos 20 hotéis existentes, sete são classificados no nível quatro e cinco estrelas (cerca de $40 \%$ da totalidade dos leitos). As locadoras são, em geral, de capital nacional, mas especializaram-se no atendimento a uma clientela padrão internacional (Queiroz 1993a). 
O desenvolvimento do turismo baseado no padrão luxo traz consigo alguns problemas. Em se tratando de mão-de-obra especializada, própria para atender este tipo de segmento, ressalta-se que o município, sendo carente desse serviço, recorre à oferta existente em outros estados ou países, deixando parte da população ativa local fora do processo. Para os visitantes de mais baixa renda, a vida noturna é deficitária, não há opções de diversão/lazer e muito menos de compras. Os atrativos não possuem infra-estrutura mínima para receber, e a cultura regional é inaproveitada; dessa forma, reduzem-se a permanência média dos turistas e a rentabilidade do setor. Em 1991, apenas $30 \%$ dos turistas consideraram boas as atrações e as opções de lazer. A permanência média máxima, que chegou aos 3 dias, foi reduzida, situando-se em torno de 1,8 dia (Queiroz 1993a).

Com relação à atividade turística, Queiroz (1993a) considera que houve várias reações por parte da comunidade de llhéus. Primeiramente, representou um certo socorro à elite ilheense endividada. A parcela que passou a depender do turismo adotou uma posição favorável e via na atividade uma possível alternativa econômica; porém, passado o impacto inicial, esse segmento da sociedade assumiu uma posição crítica à participação de capitais externos. Os não-vinculados ao setor sentiram os reflexos da aglomeração de turistas na cidade durante as altas temporadas, refletida na devastação do patrimônio e nas altas dos preços, resultado do aumento da procura por bens e serviços.

Por certo, a atividade turística ilheense ainda não conseguiu promover uma nova dinâmica à economia municipal, pela inexistência de articulação entre o turismo, economia, cultura e sociedade local. A ausência de planejamento estratégico prévio e a reduzida atuação do Estado como provedor e, ou, regulador, eliminando os atuais pontos de estrangulamento, são considerados problemas graves presentes em Ilhéus, dado que "o fomento 
a equipamentos turísticos individualmente, ..., não promoverá, por si só, um novo dinamismo a esta zona" (Queiroz 1993a, p.88).

Santos (1999) analisou as dificuldades encontradas pelos agentes receptivos ilheenses, na venda do "destino Ilhéus". Dado o número reduzido das agências de turismo, realizou-se o censo, através de visitas e, posteriormente, análise descritiva das variáveis quantitativas e qualitativas. Estas últimas foram transformadas em valores quantitativos, segundo a Escala de Likert. Porém, por envolver questões subjetivas, em sua maioria, os critérios de avaliação dos atrativos naturais e culturais não apresentam-se claramente fundamentados e delimitados.

Ao fim da pesquisa de Santos (1999), constatou-se que o litoral firma-se como o maior atrativo da cidade de llhéus. Dos agentes de turismo, $20 \%$ consideram as praias ótimas, $60 \%$ boas e $20 \%$ regulares. No entanto, os demais atrativos turísticos, como a Lagoa Encantada, o Rio do Engenho, as Fazendas de Cacau e o patrimônio histórico/cultural e sacro encontram-se em condições desfavoráveis à realização do turismo de qualidade. De todos os agentes receptivos, $80 \%$ consideraram a falta de opção noturna a principal dificuldade encontrada na venda do "destino Ilhéus". A má infra-estrutura foi citada por $60 \%$ das agências. Falta de conscientização popular, ausência de investimento no setor e preços elevados foram citados por $20 \%$ dos entrevistados.

Os resultados da pesquisa de Santos (1999) indicam algumas modificações para a indústria turística ilheense. Faz-se necessário investir na conscientização da sociedade quanto à importância do turismo, incentivar a ampliação e qualificação dos produtos turísticos e capacitação de todos agentes atuantes no setor. Ampliar o número de eventos através do desenvolvimento do turismo de esporte, de negócios, científico e ecológico são algumas das possibilidades. Para isso, deve-se buscar parcerias para o 
investimento na região, por meio do fortalecimento das relações entre os órgãos públicos e a iniciativa privada. A criação da legislação de preservação também constitui uma ação imprescindível à garantia de qualificação do turismo. Mesmo desconsiderando as questões "propaganda e marketing", importantes variáveis para o sucesso de um empreendimento, Santos (1999) assegura que os problemas locais detectados impedem a melhoria da qualidade dos serviços, o aumento da demanda turística e, conseqüentemente, maiores benefícios para os agentes receptivos e para o município.

Diagnóstico semelhante ao estudo de Santos (1999) é descrito por Gomes (1999), ao analisar a prática do Ecoturismo na "Lagoa Encantada", localizada no município de llhéus. A coleta de dados primários e secundários objetivou caracterizar e descrever os recursos naturais, a infra-estrutura, o sistema de visita ao parque, o quadro de funcionários e o nível de interação da comunidade local, dentre outras informações obtidas nas áreas sobre jurisdição imediata da Área de Proteção Ambiental (APA) ou não. Da mesma forma que no trabalho anterior, a subjetividade presente no delineamento das variáveis pesquisadas podem impedir a confiabilidade plena dos resultados apresentados.

Segundo Gomes (1999), a "Lagoa Encantada" possui rios e cachoeiras; há grande diversidade biológica e bastante água doce, que fazem jus à denominação recebida; no entanto, a área encontra-se mal explorada e bastante degradada. Até o presente momento, inexistem estudos sobre o impacto do turismo na área e sobre o perfil dos seus visitantes. Não há programação definida para os turistas, e a divulgação apresenta-se escassa. Em relação às instalações o quadro de descaso é semelhante, pois não existe infra-estrutura que permita classificar a Lagoa Encantada como um produto turístico. $O$ número de funcionários é pequeno e desqualificado, comprometendo o atendimento aos visitantes. Ademais, nenhuma parte da APA registra mata virgem, e sua renovação é lenta e frágil. Diante dessa 
situação, faz-se necessário elaborar planos estratégicos que redirecione a exploração da atividade turística na Lagoa Encantada, de forma eficiente e sustentável, como suporte para viabilizar a indústria turística de llhéus.

O trabalho de Souza (1997a), embora enfatize as condições do turismo de llhéus na baixa estação, também apresenta análises mais gerais. As conclusões foram fundamentadas nas entrevistas e informações obtidas junto a Ilhéustur, as quais, em sua maioria, não contempla o tema proposto, mas trazem resultados instigantes. Indicam que o fluxo turístico desse município apresentou um decréscimo assustador em todos os meses do ano e na maior parte da década de 90.

Dentre os fatores determinantes do limitado crescimento do turismo ilheense, um dos mais observados é o não-aproveitamento do potencial em termos de atrativos existentes. Detentor de vários atributos como beleza natural, sol quase permanente e tranqüilidade local, Ilhéus poderia absorver maior número de visitantes explorando diversos tipos de turismo. O patrimônio cultural/literário propiciado pela formação histórica também é desperdiçado. Ilhéus serviu de inspiração para escritores renomeados, como Jorge Amado e de cenário para duas novelas do maior meio de comunicação formador de opinião, que é o sistema de televisão Rede Globo. Esses episódios não modificaram o quadro do turismo local. Segundo Souza (1997a), "nem só de praia vive o turista", por isto é preciso investir nos outros potenciais, como o ecoturismo de baixo risco e o incipiente turismo de negócios.

Gasparetto (1998a), numa reflexão sobre as perspectivas da região cacaueira na era da globalização, discute que o problema do turismo de llhéus não se restringe apenas à deficiência de infra-estrutura. Nesse artigo, o autor destaca que a ausência de investimentos (principalmente público) no preparo e educação da sociedade impede que uma cidade ou região de recursos e 
pontos turísticos alcance a necessária consistência para um arrancada desenvolvimentista sólida e estável.

Após pesquisa realizada no ano de 1997, Gasparetto (1998a) descreve as avaliações, realizadas pelo cidadão ilheense, sobre a estrutura do município. Os dados revelam que $39,4 \%$ dos entrevistados consideram a cidade "bem preparada" para receber turistas, enquanto 35,6\% consideram-na "mais ou menos apta". Apenas 5,5\% avaliam Ilhéus como "muito bem preparada", contra os $9,4 \%$ que a consideram como um local "muito mal aparelhado".

Sobre o serviço de coleta de lixo e de limpeza pública, o trabalho de (Gasparetto 1998a) registrou o quadro mais alarmante: $67,2 \%$ das respostas o definiram como "péssimo" e 14,7\% como "ruim"; somente 3,5\% classificaramno como "bom". Para os moradores ilheenses, os fatores que mais incomodaram o turista foram a sujeira da cidade $(21,5 \%)$, falta de segurança $(1,7 \%)$, falta de água $(1,4 \%)$, falta de organização $(1,3 \%)$, inexistência de "vida noturna" (1,1\%), a ausência de áreas de lazer $(1 \%)$ e ausência de estradas adequadas $(0,8 \%)$.

A pesquisa de Gasparetto (1998a) revela que os visitantes gostaram das praias $(56,3 \%)$, da paisagem $(3,7 \%)$, da beleza da cidade $(3,2 \%)$, da comida (2,5\%) e da "Lagoa Encantada" (1,8\%). Número reduzido dos entrevistados, cada um dos pontos apresentando 0,1\% de aprovação, disse gostar de curtir a cidade, do turismo ecológico e do chocolate, ocorrências surpreendentes numa área de Mata Atlântica e conhecida como "terra do cacau", onde estes produtos poderiam constituir fortes atrativos para os visitantes.

Os resultados apresentados por Gasparetto (1998a) evidenciam que quanto à recepção, 38,7\% percebem que o turista é "mais ou menos bem acolhido", $26,1 \%$ acham o visitante "mal recebido" e 7,6\% acreditam que o 
ilheense "recepciona muito mal". Indagou-se, ainda, sobre o contato do visitante com o morador do município, formulando a seguinte questão: "algum turista the pediu informações no último verão?". Do total de pessoas abordadas, 64,8\% responderam que "não" estabeleceram contato e apenas 9,7\% disseram que "somente um turista" manteve certa aproximação. Os nativos reconhecem que a exploração $(3 \%)$, o ser maltratado $(1,1 \%)$, a carestia e pobreza $(15,6 \%)$ são outros fatores que incomodam o turista.

Das expectativas da população local, Gasparetto (1998a) descreve: $22 \%$ dos nativos desejam maior e melhores empregos, e $23,9 \%$ pontuam as questões relacionadas à renda como impedimento para que se considerem pessoas felizes, ou seja, quase $50 \%$ dos ilheense desejam ampliar os níveis de emprego e renda. Dessa forma, estas informações além de indicadores da realidade, apresentam o desafio a ser enfrentado para que a atividade turística local deixe de experimentar instabilidades e venha a promover melhoria da qualidade de vida da população ilheense.

Em suma, as pesquisas apontadas salientam a importância da administração da indústria turística, para garantir 0 atendimento das perspectivas dos turistas, a permanência dos fluxos contínuos das visitas e a geração de benefícios sociais, culturais e econômicos para a comunidade local. Por isso, esses trabalhos indicam como meta ampliar o leque de opções para os turistas, melhorar a infra-estrutura, mensurar o padrão espacial dos recursos turísticos e da potencialidade atrativa da área e ampliar os gastos do governo local. Ademais, a elaboração e administração de projetos ambientais que garantam a manutenção da produtividade de longo prazo e a preservação dos valores culturais, sociais e históricos, também são consideradas estratégias fundamentais. Portanto, as técnicas, os modelos, os dados registrados e as análises realizadas, com relação à estrutura turística, trouxeram informações úteis para a orientação da administração pública e privada que objetive a exploração turística eficiente e capaz de promover o desenvolvimento 
sustentável. Nos Apêndices A e B, respectivamente, são revistos alguns trabalhos empíricos sobre os efeitos dos estoques de capitais social e natural no funcionamento das economias de alguns países selecionados. 


\section{METODOLOGIA}

É possível verificar que o desempenho e o impacto da atividade turística nas economias locais têm se apresentado de forma distinta. Algumas cidades, regiões e países experimentam o progresso advindo da exploração de um turismo eficiente. Porém, outras áreas têm desenvolvido um turismo ineficiente, que gera um crescimento local limitado. Diante deste quadro, por certo, cabe também ao demandante, no caso o próprio turista, avaliar as condições favoráveis e desfavoráveis da estrutura turística que tem determinado a qualificação do setor e, consequentemente, sua satisfação.

\section{1 Área estudada, indicadores e fonte de dados}

As características da área estudada sinalizam a importância de Ilhéus como pólo turístico. O município situa-se ao sul do Estado da Bahia, limitando-se ao leste com o oceano Atlântico. A área é de $1.847,7 \mathrm{~km}^{2}$, com altitude de 45 metros. A temperatura média é de $28^{\circ} \mathrm{C}$, sendo que em fevereiro, esta atinge $30,3^{\circ} \mathrm{C}$ e, em agosto chega a $17,1^{\circ} \mathrm{C}$. A pluviosidade é elevada, registrando-se $1.706,5 \mathrm{~mm}$ anuais; onde no verão as chuvas são mais fortes e rápidas e no inverno, são mais fracas e prolongadas ${ }^{35}$.

$\mathrm{Na}$ presente pesquisa, foi analisada a qualificação da oferta turística do município de llhéus, através de vários indicadores. A escolha desses indicadores se fez levando em consideração variáveis sugeridas em trabalhos

\footnotetext{
${ }^{35}$ De acordo com a Comissão Executiva do Plano da Lavoura Cacaueira (CEPLAC), citado por Santos (1999).
} 
similares como o de Beni (1998), Kozak \& Rimmington (2000) e Luzar et al. (1998).

Em relação à fonte de dados, aplicou-se um questionário (Anexo C) junto aos turistas, composto de 54 questões, abordando o mesmo número de indicadores, descritos a seguir:

- Atividade turística do município de llhéus

Indicador 1 - Meios de hospedagem

Indicador 2 - Equipamentos de lazer e entretenimento

Indicador 3 - Comércio em geral

Indicador 4 - Comércio de artesanatos

Indicador 5 - Serviços de higiene e limpeza

Indicador 6 - Serviços de alimentação

Indicador 7 - Passeios oferecidos

Indicador 8 - Serviços de recepção, informação e guias de turismo

Indicador 9 - Patrimônio histórico/cultural

Indicador 10 - Manifestações populares

Indicador 11 - Entretenimentos/diversões diurnas

Indicador 12 - Entretenimentos/diversões noturnas

- Infra-estrutura do município de llhéus:

Indicador 13 - Abastecimento de água 
Indicador 14 - Pavimentação das ruas

Indicador 15 - Sinalização urbana (do DETRAN)

Indicador 16 - Sinalização turística

Indicador 17 - Limpeza pública

Indicador 18 - Segurança pública

Indicador 19 - Meios de comunicação

Indicador 20 - Meios de transportes inter (municipais, regionais, estaduais)

Indicador 21 - Meios de transportes intra-urbano

- Facilidades de pagamento/financiamento dos custos da viagem

Indicador 22 - Acesso aos serviços bancários

Indicador 23 - Aceitação de pagamentos (cartão crédito/cheques diversos ...)

Indicador 24 - Valor das diárias dos meios de hospedagem

Indicador 25 - Preços dos serviços de alimentação

Indicador 26 - Preços dos serviços de lazer e entretenimento

- Recursos naturais presentes no município de llhéus

Indicador 27 - Amenidades ambientais (beleza das praias, rios, lagoas ...)

Indicador 28 - Coleta de lixo nas praias, rios, lagoas, mangues...

Indicador 29 - Limpeza dos banheiros das praias, rios, lagoas, mangues...

Indicador 30 - Distribuição das redes de esgotos próximos às praias/rios ... 
Indicador 31 - Aspecto visual das barracas/cadeiras ... das praias/rios/lagoas ...

Indicador 32 - Pagamento de uma taxa para preservação e manutenção dos recursos naturais (valores apresentados aos turistas de forma aleatória)

Indicador 33 - Sim ( ) Não ( )

(disposição a pagar a taxa referente à preservação e manutenção dos recursos naturais; do Indicador 32)

- Capacitação (nível de qualificação/preparo/conhecimento)

Indicador 34 - Dos profissionais diretamente envolvidos na atividade turística

Indicador 35 - Das pessoas indiretamente envolvidas na atividade turística

- Sobre a população ilheense, avalie

Indicador 36 - Receptividade

Indicador 37 - Confiança

- Outros indicadores

Indicador 38 - Influência da viagem

Indicador 39 - Nota geral (avaliação geral ou satisfação total do turista) ao turismo do município de llhéus

Indicador 40 - Pretensão em voltar a visitar a cidade de llhéus

Indicador 41 - Pretensão em recomendar uma visita à cidade de llhéus

- Identificação do turista e informações adicionais

Indicador 42 - Sexo 
Indicador 43 - Quantos dias que visita a cidade de llhéus

Indicador 44 - Cidade de origem

Indicador 45 - Estado de origem

Indicador 46 - País de origem

Indicador 47 - Motivo da viagem a llhéus

Indicador 48 - Número de pessoas que viajavam com o turista

Indicador 49 - Faixa etária

Indicador 50 - Estado civil

Indicador 51 - Grau de instrução

Indicador 52 - Profissão (Ocupação Principal)

Indicador 53 - Faixa da renda mensal individual

Indicador 54 - Meio de transporte utilizado para chegar a llhéus

A maioria dos indicadores, precisamente 36 , foram avaliados ao atribuir-Ihes notas, entre zero e 10. Estes, concomitantemente, foram classificados segundo a noção de estoque de capital (físico, financeiro, humano, social e natural) (Tabela 1), exceto o "Indicador 39 - Nota geral (avaliação geral ou satisfação total do turista) ao turismo do município de Ilhéus". 
Tabela 1. Indicadores dos estoques de capitais (físico, financeiro, humano, social e natural) referentes à estrutura turística.

\begin{tabular}{|c|c|}
\hline $\begin{array}{c}\text { Estoques } \\
\text { de } \\
\text { Capitais }\end{array}$ & Indicadores \\
\hline $\begin{array}{l}\text { Capital } \\
\text { Físico }\end{array}$ & $\begin{array}{ll}- & \text { Indicador } 1 \text { - Meios de hospedagem } \\
- & \text { Indicador } 2 \text { - Equipamentos de lazer/entretenimento } \\
- & \text { Indicador } 3 \text { - Comércio em geral } \\
- & \text { Indicador } 7 \text { - Passeios oferecidos } \\
- & \text { Indicador } 9 \text { - Patrimônio histórico/cultural } \\
- & \text { Indicador } 10 \text { - Manifestações populares } \\
- & \text { Indicador } 11 \text { - Entretenimentos/diversões diurnas } \\
- & \text { Indicador } 12 \text { - Entretenimentos/diversões noturnas } \\
- & \text { Indicador } 13 \text { - Abastecimento de água } \\
- & \text { Indicador } 14 \text { - Pavimentação das ruas } \\
- & \text { Indicador } 15 \text { - Sinalização urbana (do DETRAN) } \\
- & \text { Indicador } 16 \text { - Sinalização turística } \\
- & \text { Indicador } 17 \text { - Limpeza pública } \\
- & \text { Indicador } 18 \text { - Segurança pública } \\
- & \text { Indicador } 19 \text { - Meios de comunicação } \\
- & \text { Indicador } 20 \text { - Meios de transportes inter (municipais, regionais, estaduais) } \\
- & \text { Indicador } 21 \text { - Meios de transportes intra-urbano }\end{array}$ \\
\hline $\begin{array}{l}\text { Capital } \\
\text { Financeiro }\end{array}$ & $\begin{array}{ll}\text { - } & \text { Indicador } 22 \text { - Acesso aos serviços bancários } \\
\text { - } & \text { Indicador } 23 \text { - Aceitação de pagamentos via cartão de crédito, cheques ... } \\
\text { - } & \text { Indicador } 24 \text { - Valor das diárias dos meios de hospedagem } \\
\text { - } & \text { Indicador } 25 \text { - Preços dos serviços de alimentação } \\
\text { - } & \text { Indicador } 26 \text { - Preços dos serviços de lazer e entretenimento }\end{array}$ \\
\hline $\begin{array}{l}\text { Capital } \\
\text { Natural }\end{array}$ & $\begin{array}{ll}\text { - } & \text { Indicador } 27 \text { - Amenidades ambientais (beleza das praias, rios ...) } \\
\text { - } & \text { Indicador } 28 \text { - Coleta de lixo das praias, rios, lagoas, mangues... } \\
\text { - } & \text { Indicador } 29 \text { - Limpeza dos banheiros existentes nas praias, rios, lagoas ... } \\
\text { - } & \text { Indicador } 30 \text { - Distribuição das redes de esgotos próximos às praias/rios ... } \\
\text { - } & \text { Indicador } 31 \text { - Aspecto visual das barracas/cadeiras, etc. das praias/rios... }\end{array}$ \\
\hline $\begin{array}{l}\text { Capital } \\
\text { Humano }\end{array}$ & $\begin{array}{ll}\text { - } & \text { Indicador } 4 \text { - Comércio de artesanatos } \\
\text { - } & \text { Indicador } 5 \text { - Serviços de higiene e limpeza } \\
\text { - } & \text { Indicador } 6 \text { - Serviços de alimentação } \\
\text { - } & \text { Indicador } 8 \text { - Serviços de recepção, informação e guias de turismo } \\
\text { - } & \text { Indicador } 34 \text { - Qualificação dos profissionais (diretos) do turismo } \\
- & \text { Indicador } 35 \text { - Qualificação das profissionais (indiretos) do turismo }\end{array}$ \\
\hline $\begin{array}{l}\text { Capital } \\
\text { Social }\end{array}$ & $\begin{array}{l}\text { - } \quad \text { Indicador } 36 \text { - Receptividade da população do município de llhéus } \\
\text { - } \quad \text { Indicador } 37 \text { - Confiança na população do município de llhéus }\end{array}$ \\
\hline
\end{tabular}

Fonte: notas da pesquisa. 
Na Tabela 1, apresentam-se alguns dos indicadores utilizados pela literatura especializada para avaliar a estrutura turística. O número de indicadores, considerado relativamente grande, dificulta a análise tabular, gráfica e mesmo estatística. Por isto, optou-se pelo uso de técnicas de análise multivariada, como a análise fatorial e a análise de componentes principais, as quais reduzem o número de variáveis consideradas a um número menor de variáveis compostas (fatores) e facilitam a análise de fenômenos. Para o processamento dos dados foi usado o "Statistical Package for the Social Sciences (SPSS)".

\subsection{Análise fatorial}

A análise fatorial é uma técnica utilizada, essencialmente, para redução e sumarização de dados, em pesquisas que trabalham com grande número de variáveis correlacionadas. A técnica identifica poucos fatores subjacentes (implícitos/não observáveis) ou construções latentes (ocultas) que explicam as correlações entre um conjunto de variáveis. Também, substitui o conjunto original de variáveis correlacionadas, por um conjunto novo e menor, de variáveis não-correlacionadas, para análise multivariada subsequente, como a regressão múltipla (Malhotra, 2001; Sharma, 1995).

\subsubsection{Considerações sobre o modelo de análise fatorial ${ }^{36}$}

A análise fatorial é realizada em várias etapas. A primeira etapa determina a matriz das correlações entre as variáveis originais. Considerando $L$ observações para os $n$ indicadores, $X_{i j}(\operatorname{com} i=1,2,3, \ldots, n$ e j $=1,2,3, \ldots, L)$ a $j$-ésima observação do $i$-ésimo indicador e que a padronização dos

\footnotetext{
${ }^{36}$ Seção baseada em Santos (2000).
} 
indicadores é realizada, defini-se a matriz de correlações simples entre os indicadores, dada por:

$\mathbf{R}=\mathbf{X X}^{\prime}$

onde:

$\mathbf{X}=\left[\begin{array}{ccc}x_{11} & x_{12} \mathrm{~K} & x_{1 L} \\ x_{21} & x_{23} \mathrm{~K} & x_{2 L} \\ \mathrm{M} & \mathrm{M} & \mathrm{M} \\ x_{n 1} & x_{n 2} \mathrm{~K} & x_{n L}\end{array}\right]=\left[\begin{array}{c}\mathbf{x}^{\prime} \\ \mathbf{x}^{\prime} \\ \mathbf{M} \\ \mathbf{x}^{\prime}\end{array}\right]$

$\mathrm{Na}$ segunda etapa, calculam-se os fatores necessários para representar as variáveis. Neste trabalho os fatores foram extraídos pelo método dos componentes principais. $O$ fator 1 representa a combinação linear que extrai a maior percentagem de variância dos indicadores. $O$ fator 2 é a próxima combinação linear que maximiza o percentual da variância restante. Os demais fatores seguem o mesmo princípio. Ademais os fatores extraídos são independentes entre si (são ortogonais).

$\mathrm{Na}$ análise fatorial cada indicador $x_{i}$ representa uma combinação linear de $m$ fatores comuns e de um fator específico. Para o $i$-ésimo indicador tem-se:

$$
x_{i j}=a_{i 1} f_{1 j}+a_{i 2} f_{2 j}+\mathrm{K}+a_{i m} f_{m j}+u_{i y} y_{i j}
$$

ou

$$
x_{i j}=\sum_{p=1}^{m} a_{i p} f_{p j}+u_{i} y_{i j}
$$

em que $f_{p j}$ é o valor do $p$-ésimo fator comum para a $j$-ésima observação. Ou seja, é o valor dos fatores comuns desde que todos os indicadores sejam 
expressos em função deles; $a_{i p}$ é coeficiente; $u_{i}$ é coeficiente; $y_{i j}$ representa o $j$-ésimo valor do $i$-ésimo fator específico. Ou seja, é o valor único que representa a parte não explicada pelos fatores comuns.

Admite-se que todos os fatores são variáveis com média zero e que seus respectivos vetores tem módulo igual a 1. Desse modo:

$$
\begin{aligned}
& \sum f_{p j}=\sum y_{i j}=0 \\
& \sum f^{2}{ }_{p j}=\sum y^{2}{ }_{i j}=1
\end{aligned}
$$

para $p=1, \mathrm{~K}, m$ e $i=1, \mathrm{~K} n$.

Representando o modelo de análise fatorial em notação matricial, tem-se:

$$
\mathbf{X}=\mathbf{A F}+\mathbf{U Y}
$$

em que

$$
\begin{aligned}
\mathbf{A} & =\left[\begin{array}{llll}
a_{11} & a_{12} & \mathrm{~K} & a_{1 \mathrm{~m}} \\
a_{21} & a_{22} & \mathrm{~K} & a_{2 \mathrm{~m}} \\
\mathrm{~K} & \mathrm{~K} & \mathrm{~K} & \mathrm{~K} \\
a_{\mathrm{n} 1} & a_{\mathrm{n} 2} & \mathrm{~K} & a_{\mathrm{nm}}
\end{array}\right]_{n \times m} \\
\mathbf{F} & =\left[\begin{array}{llll}
f_{11} & f_{12} & \mathrm{~K} & f_{1 \mathrm{~L}} \\
f_{21} & f_{22} & \mathrm{~K} & f_{2 \mathrm{~L}} \\
\mathrm{~K} & \mathrm{~K} & \mathrm{~K} & \mathrm{~K} \\
f_{\mathrm{m} 1} & f_{\mathrm{m} 2} & \mathrm{~K} & f_{\mathrm{mL}}
\end{array}\right]_{m \times L} \\
\mathbf{U} & =\left[\begin{array}{llll}
u_{1} & 0 & \mathrm{~K} & 0 \\
0 & u_{2} & \mathrm{~K} & 0 \\
\mathrm{~K} & \mathrm{~K} & \mathrm{~K} & \mathrm{~K} \\
0 & 0 & \mathrm{~K} & u_{\mathrm{n}}
\end{array}\right]_{n \times n}
\end{aligned}
$$


$\mathbf{Y}=\left[\begin{array}{llll}y_{11} & y_{12} & \mathrm{~K} & y_{1 \mathrm{~L}} \\ y_{21} & y_{22} & \mathrm{~K} & y_{2 \mathrm{~L}} \\ \mathrm{~K} & \mathrm{~K} & \mathrm{~K} & \mathrm{~K} \\ y_{\mathrm{n} 1} & y_{\mathrm{n} 2} & \mathrm{~K} & y_{\mathrm{nL}}\end{array}\right]_{n \times L}$

em que

A : matriz dos coeficientes dos fatores comuns;

F : matriz dos fatores comuns na qual cada linha corresponde a um fator;

$\mathbf{U}$ : matriz dos coeficientes dos fatores específicos; e

Y : matriz dos fatores específicos.

Admite-se que todos os fatores são ortogonais entre si e com vetores com módulo igual a 1; então, a partir dessas duas pressuposições, pode-se definir que:

$\mathbf{F F}^{\prime}=\mathbf{I} m$ (matriz unitária de ordem $m$ )

$\mathbf{Y Y}^{\prime}=\mathbf{I} n$ (matriz unitária de ordem $\left.\mathrm{n}\right)$

Admite-se, também, que os $m$ fatores comuns são ortogonais com os $n$ fatores específicos, resultando numa matriz de zeros, assim:

$\mathbf{F Y} \mathbf{Y}^{\prime}=\mathbf{0}$.

Sabe-se que $\mathbf{R}=\mathbf{X X}^{\prime}$,

Como $\mathbf{X}=\mathbf{A F}+\mathbf{U F}$; então:

$\mathbf{R}=(\mathbf{A F}+\mathbf{U F})\left(\mathbf{F}^{\prime} \mathbf{A}^{\prime}+\mathbf{Y}^{\prime} \mathbf{U}^{\prime}\right)$

$\mathbf{X X} \mathbf{X}^{\prime}=\mathbf{A F F}^{\prime} \mathbf{A}^{\prime}+\mathbf{A F Y} \mathbf{Y}^{\prime}+\mathbf{U Y F}^{\prime} \mathbf{A}^{\prime}+\mathbf{U Y Y} \mathbf{Y}^{\prime} \mathbf{U}^{\prime}$ 
Dado que $\mathbf{F F} \mathbf{F}^{\prime}=\mathbf{1} ; \mathbf{F} \mathbf{Y}^{\prime}=\mathbf{0} ; \mathbf{Y} \mathbf{F}^{\prime}=\mathbf{0} ; \mathbf{Y} \mathbf{Y}^{\prime}=\mathbf{1}$

$\mathbf{X} \mathbf{X}^{\prime}=\mathbf{A} \mathbf{A}^{\prime}+\mathbf{U}^{\prime}$

então,

$\mathbf{R}=\mathbf{X} \mathbf{X}^{\prime}=\mathbf{A} \mathbf{A}^{\prime}+\mathbf{U}^{2}$

De acordo com essa relação, para cada elemento da diagonal $\mathbf{R}$ (que é sempre 1), tem-se:

$1=\sum_{j=1}^{L} x_{i j}^{2}=\sum_{p=1}^{m} a_{i p}^{2}+u_{i}^{2}$

Os termos do último membro dessa expressão representam as proporções da variância de $x_{i}$, devido aos fatores comuns e aos fatores específicos.

A soma dos quadrados das variáveis de uma linha da matriz das cargas fatoriais denomina-se comunalidade. Esta corresponde à proporção da variância total de cada variável que é explicada pelo conjunto de fatores. Os valores da comunalidade estão num intervalo de 0 e 1. Quanto mais próximo de 1, maior será a contribuição do fator para explicação de determinado indicador. É expressa por:

$$
h^{2}{ }_{i}=\sum_{p=1}^{m} a^{2}{ }_{i p}
$$

A proporção da variância do $i$-ésimo indicador explicado pelo fator específico é $u_{i}$ e denomina-se especificidade do indicador. Assim:

$$
h^{2}+u^{2}{ }_{i}=1
$$

Na terceira etapa, os fatores extraídos são submetidos a um rotação. O objetivo da rotação ortogonal consiste em transformar os fatores obtidos em 
novos fatores independentes. Com isso, espera-se que os indicadores que tenham correlação mais forte entre si estejam dentro de um mesmo fator, facilitando a interpretação dos mesmos. A rotação altera a parcela de contribuição de cada fator, mas mantém os valores das comunalidades e a proporção da variância explicada pelo conjunto de fatores. O critério utilizado de transformação ortogonal dos fatores foi o Varimax.

\subsubsection{Estatísticas associadas à análise fatorial}

- Medida de adequação da amostra de Kaiser-Meyer-Olkin (KMO)

Índice usado para avaliar a adequacidade da análise fatorial. Valores altos (entre 0,5 e 1,0) indicam que a análise fatorial pode ser adequada, significando que as correlações entre pares de variáveis podem ser explicadas por outras variáveis. É uma medida da homogeneidade das variáveis.

- Teste da esfericidade de Bartlett

Estatística formal que testa a conveniência do modelo fatorial. Testa a hipótese nula de que as variáveis sejam não-correlacionadas na população. Isto é, testa a hipótese de que a matriz de correlação populacional é uma matriz identidade (apresentando o valor um nos termos da diagonal e valor zero nos termos fora da diagonal). Portanto, a estatística de teste de esfericidade se baseia em uma transformação qui-quadrado do determinante da matriz de correlação, em que um valor elevado da estatística de teste favorece a rejeição da hipótese nula e estabelece a conveniência da análise fatorial, ou seja, para que a análise fatorial seja apropriada, as variáveis devem ser correlacionadas. Dessa forma, a matriz da correlação populacional não deve ser uma matriz identidade. 
- Determinação do número de fatores

i) Determinação com base em autovalores

Autovalor (eigenvalue) representa a variância explicada por cada fator. Nesta abordagem, são retidos apenas os fatores com autovalores (variâncias) superiores a 1. Fatores com variância menor que 1 não são melhores do que uma variável isolada, porque devido à normalização, cada variável já possui variância igual a 1 .

ii) Determinação com base na percentagem da variância

Nesta abordagem, determina-se o número de fatores com base na percentagem acumulada da variância extraída pelos fatores. Recomenda-se que os fatores extraídos respondam por, no mínimo, $60 \%$ da variância.

- Interpretação dos fatores

Após a rotação de fatores, a interpretação é facilitada ao identificar as variáveis que apresentam grandes cargas sobre o mesmo fator. Neste trabalho foi considerado os coeficientes de correlação entre cada fator e cada indicador, isto é, as cargas fatoriais acima de 0,60 , em valor absoluto ${ }^{37}$. Então, o fator deve ser interpretado em termos das características das variáveis que o compõe.

\footnotetext{
${ }^{37}$ Para estabelecer o valor, em módulo, de 0,60 da carga fatorial teve-se como referência os seguintes trabalhos: Santos (2000); Shikida (1997); Figueiredo (1985).
} 


\subsection{Análise de regressão}

\subsubsection{O modelo econométrico}

Neste trabalho, a estimativa dos parâmetros da equação da estrutura turística de llhéus foi realizada através da regressão linear múltipla. Esta equação foi formulada da seguinte forma:

$N G=f(F, I, R, S, G, E c, \operatorname{Inf}$, Mot $)$

em que

$N G$ = nota geral (avaliação geral ou satisfação total do turista);

$F=$ escores fatoriais (extraídos dos indicadores da estrutura turística);

$I$ = idade (faixa etária, em anos) do turista;

$R$ = faixa de renda mensal individual do turista;

$S$ = sexo do turista (variável dummy);

$G$ = grau de instrução do turista - nível de escolaridade (variável dummy);

$E c$ = estado civil do turista (variável dummy);

Inf = influência da viagem (variável dummy); e

Mot = motivo da viagem (variável dummy).

As variáveis foram definidas e mensuradas conforme os trabalhos de Andereck \& Vogt (2000) e Kozak \& Rimmington (2000). Para obter as estimativas dos parâmetros associados com as variáveis anteriormente apresentadas, especificou-se o seguinte modelo econométrico: 
$Y_{j}=\sum_{i=1}^{7} \alpha i F i j+\sum_{i=1}^{7} \beta_{i} X_{i j}=u_{j} \quad(\mathrm{j}=1,2, \mathrm{~K}, 125)$

em que

$Y_{j}=$ nota geral do turista $j$ (avaliação geral ou satisfação total do visitante $j$ com o turismo de llhéus);

$F_{1 j}=$ fator 1 - manutenção e preservação do capital natural;

$F_{2 j}=$ fator 2 - capital humano associado aos serviços de entretenimento;

$F_{3 j}=$ fator 3 - capital humano associado à qualidade de serviços hoteleiros e de passeios e capital social;

$F_{4 j}=$ fator 4 - capital físico básico associado à distribuição de água e pavimentação das ruas;

$F_{5 j}=$ fator 5 - capital humano associado à capacidade de expressão da cultura popular;

$F_{6 j}=$ fator 6 - capital físico básico associado aos meios de comunicação; e

$F_{7 j}=$ fator 7 - capital natural.

A variável $X_{1}$ refere-se a idade (faixa etária) dos turistas:

$X_{1 j}=$

1 se o turista $j$ possui menos que 18 anos

2 se o turista $j$ possui entre 19 e 25 anos 
3 se o turista $j$ possui entre 26 e 35 anos

4 se o turista $j$ possui entre 36 e 50 anos

5 se o turista $j$ possui entre 51 e 65 anos

6 se o turista $j$ possui mais de 65 anos

A variável $X_{2}$ refere-se à renda individual mensal dos turistas, em $\mathrm{R} \$$.

$X_{2 j}=$

1 se o turista $j$ possui renda de até 604,00

2 se o turista $j$ possui renda de 605,00 a 755,00

3 se o turista $j$ possui renda de 756,00 a $1.359,00$

4 se o turista $j$ possui renda de $1.360,00$ a $1.510,00$

5 se o turista $j$ possui renda de $1.511,00$ a $2.114,00$

6 se o turista $j$ possui renda de $2.115,00$ a $2.265,00$

7 se o turista $j$ possui renda de $2.266,00$ a $2.869,00$

8 se o turista $j$ possui renda de $2.870,00$ a $3.020,00$

9 se o turista $j$ possui renda de $3.021,00$ a $3.624,00$

10 se o turista $j$ possui renda de $3.625,00$ a $3.775,00$

11 se o turista $j$ possui renda de $3.776,00$ a $4.379,00$ 
12 se o turista $j$ possui renda de $4.380,00$ a $4.530,00$

13 se o turista $j$ possui renda de $4.531,00$ a $5.134,00$

14 se o turista $j$ possui renda a partir de $5.135,00$

A variável $X_{3}$ refere-se ao sexo do visitante:

$X_{3 j=}$

1 se o turista $j$ for do sexo masculino

0 se o turista $j$ for do sexo feminino

A variável $X_{4}$ refere-se ao grau de instrução (nível de escolaridade) do turista:

$X_{4 j}=$

1 se o turista $j$ possui nível superior

0 caso contrário

A variável $X_{5}$ refere-se ao estado civil do visitante:

$X_{5 j}=$

1 se o turista $j$ for casado

0 caso contrário

A variável $X_{6}$ refere-se aos fatores que influenciaram a viagem:

$X_{6 j}=$

1 se o turista $j$ foi influenciado por "comentário de parentes e amigos" 
0 para as demais influências.

A variável $X_{7}$ refere-se aos fatores que motivaram a viagem do turista:

$X_{7 j}=$

1 se o motivo da viagem do turista $j$ foi "passeio/lazer"

0 para os demais motivos

$\alpha_{i} e \beta_{i}=$ são os parâmetros estimados $(i=1,2, \ldots, 7)$

$u_{j}=$ são erros aleatórios que obedecem as pressuposições usuais.

Em condições normais, as restrições ao modelo apresentado foram atendidas:

$\alpha_{i}=\partial Y_{j} / \partial F_{i j}>0$

Os sinais dos parâmetros $\beta_{1}, \beta_{2}, \beta_{3}, \beta_{4}, \beta_{5}, \beta_{6}, \beta_{7}$, das variáveis idade $\left(X_{1}\right)$, renda $\left(X_{2}\right)$, sexo $\left(X_{3}\right)$, nível de instrução $\left(X_{4}\right)$, estado civil $\left(X_{5}\right)$, influência da viagem ( $\left.X_{6}\right)$ e motivo da viagem $\left(X_{7}\right)$, não são pré-definidos pela literatura.

A literatura não esclarece sobre a forma funcional do modelo econométrico estimado. Por isso, foram testadas as seguintes formulações: forma linear, forma semi-logarítimica na variável dependente, forma semilogarítimica na variável independente e a forma logarítimica nas variáveis dependente e independentes; sempre aplicando logaritmos apenas nas variáveis que não sejam dummies. Portanto, foram estimados quatro modelos econométricos diferentes mas, em seguida foi analisada somente a forma funcional que obteve o melhor resultado estatístico. 


\section{RESULTADOS E DISCUSSÃO}

Neste capítulo, a atividade turística de llhéus é avaliada através de vários indicadores. Inicialmente, procedeu-se à uma análise descritiva dos dados relacionados à estrutura turística. Dos modelos econométricos, o procedimento adotado, primeiramente, foi a análise fatorial pelo método dos componentes principais, objetivando reduzir as variáveis incluídas na pesquisa. Em seguida, através da regressão múltipla, procurou-se estimar a relação entre os fatores (indicadores da estrutura turística), características dos visitantes e da viagem e a nota geral (avaliação geral ou satisfação total) atribuída ao turismo ilheense.

\subsection{Notas sobre a pesquisa e tratamento dos indicadores referentes à estrutura turística de Ilhéus}

A pesquisa foi realizada via levantamento, com base em dados primários. Para a coleta das informações, aplicou-se um questionário, composto de 54 questões (Anexo C), das quais 36 são indicadores avaliados por meio de notas, entre zero e 10 . Foram entrevistados 125 turistas que estavam visitando Ilhéus, entre 05 de março a 15 de abril de 2001, há pelo menos três dias. A reduzida disponibilidade de pessoal e tempo, por parte da equipe do pesquisador, constituiu os fatores determinantes do total de visitantes abordados e do período da pesquisa de campo. Assim, na coleta de informações realizada na "baixa estação", de reduzida demanda, procurou-se indagar o maior número possível de turistas, sem calcular o tamanho apropriado da amostra. 
Buscou-se entrevistar, aleatoriamente, os turistas presentes em todo o território, ou seja, como a cidade de llhéus possui atrativos turísticos distribuídos no norte, sul e centro, pretendeu-se abordar os visitantes dos mais diversos tipos de pousadas/hotéis, camping e demais estabelecimentos dessas áreas. Também, objetivou-se entrevistar os turistas no aeroporto, na rodoviária e nas principais saídas do município (postos da polícia rodoviária). Tudo isso com o intuito de registrar a opinião das pessoas das diversas classes sociais. No entanto, nessa época, só foi viável a aplicação dos questionários em hotéis e pousadas de médio e grande portes (Anexo D), principalmente nos resorts do centro e sul do município. Verificou-se que as pequenas pousadas e hotéis encontravam-se, em sua grande maioria, com reduzida taxa de ocupação ou fechados devido à concorrência com os médios e grandes empreendimentos, que garantiram sua clientela ao oferecem pacotes e preços reduzidos, bem como instalações de maior qualidade.

Do total de indicadores controlados no questionário e de visitantes abordados, definiu-se a matriz de observações. Inicialmente, esta matriz foi composta de 125 linhas (número de turistas entrevistados) e 54 colunas (número de variáveis relacionadas). Porém, seis variáveis foram excluídas dos modelos econométricos. O "Indicador 52 - Ocupação principal" não foi tabulado e os outros cinco foram desconsiderados devido à quantidade de respostas inexistentes/ausentes (valores missing). Assim, a matriz de observações considerada ao longo do trabalho foi composta de 125 linhas (número de turistas entrevistados) e 48 colunas (número de variáveis relacionadas e válidas).

Quando mais que 25 entrevistados (ou $20 \%$ do total de turistas) optaram ou não puderam avaliar determinado indicador, esta variável foi abandonada nas estimativas das análises fatorial e de regressão. Como apresentado na Tabela 2, estão inseridos neste caso cinco indicadores: o 
"Indicador 10 - Manifestações populares", "Indicador 12 Entretenimentos/diversões noturnas", "Indicador 20 - Meios de transportes intermunicipais/inter-regionais/inter-estaduais", "Indicador 21 - Meios de transportes intra-urbano" e o "Indicador 26 - Preços dos serviços de lazer e entretenimento".

Quando a variável apresentou menos que 25 respostas inexistentes/ausentes (ou não mais que $20 \%$ de valores missing), esta foi aproveitada e inserida nos modelos desenvolvidos. Cada observação não avaliada foi substituída por uma média. Esta média foi calculada somando-se a média das notas da linha (média das notas registradas pelo entrevistado) com a média das notas da coluna (média das notas registradas para aquela variável), dividida por dois ${ }^{38}$.

Para a análise fatorial, consideraram-se, apenas, os indicadores avaliados por meio de notas, entre zero e 10. Inicialmente, os indicadores foram representados pela matriz de observações, constituída de 125 linhas e 35 colunas (excetuando o "Indicador 39 - Nota geral"39). Entretanto, conforme evidenciado anteriormente, cinco indicadores (avaliados por meio de notas) foram eliminados, dado o número de valores missing observados ${ }^{40}$. Assim, apenas 30 variáveis foram inseridas na estimativa dos fatores, representadas através da matriz composta de 125 linhas e 30 colunas.

\subsection{Análise descritiva sobre a estrutura turística de llhéus}

$\mathrm{Na}$ Tabela 2, resumem-se várias informações sobre os itens relacionados à estrutura turística de Ilhéus. Apresentam-se, nessa tabela, valores missing, média, moda, desvio padrão e variância de cada indicador que

\footnotetext{
${ }^{38}$ Quando, por exemplo, o "turista $-x$ " escolheu não registrar uma nota ao "Indicador 1 - Meios de hospedagem", estimou-se a média de todas as notas do "turista - $x$ ", somando-a à média das notas dadas por todos os outros turistas ao "Indicador 1 - Meios de hospedagem", dividindo-as por 2 .

39 Este indicador é considerado variável dependente na análise de regressão (apresentada a seguir), por isso não foi incluído na análise fatorial.

${ }^{40}$ O sexto indicador, não tabulado, o "Indicador 52 - Ocupação principal", não se insere no caso das variáveis medidas por meio de notas.
} 
foi avaliado através de notas entre zero e 10. Com relação às variáveis com grande quantidade de missing observados ${ }^{41}$, cinco se destacam, por motivos diversos, e são consideradas casos mais graves, dada a dificuldade em atribuirIhes notas. Houve muita relutância por parte dos turistas para avaliar o "Indicador 10 - Manifestações populares (folclore)", o qual registrou o maior número de valores missing, 56. Essa variável obteve, em média, a menor nota atribuída, 4,83, sendo, assim, considerada pelos respondentes o pior serviço oferecido ou até mesmo inexistente.

O "Indicador 20 - Meios de transportes intermunicipais/regionais/estaduais" e o "Indicador 21 - Meios de transportes intraurbano", registraram, respectivamente, 42 e 33 missing. Esses itens foram assim avaliados dada a especificidade dos visitantes entrevistados no período. A maioria dos turistas não pôde avaliar tais indicadores, já que alguns realizavam o passeio de carro próprio e outros estavam em llhéus de excursão, com ônibus alugado (Anexo D). Portanto, poucas pessoas utilizaram os meios de transporte local. Porém, embora se tenha registrado quantidade semelhante de missing em relação ao indicador 10, os indicadores 20 e 21 obtiveram nota média superior (respectivamente 7,19 e 6,96), sendo mais bem avaliados por aqueles que utilizaram transporte local durante a visita.

\footnotetext{
41 Estão inseridos nestes casos os indicadores que registraram mais que 25 respostas inexistentes/ausentes (mais que $20 \%$ de missing).
} 
Tabela 2. Estatísticas descritivas das notas registradas (entre 0 e 10) das variáveis referentes à estrutura turística do município de lhéus (BA).

\begin{tabular}{|c|c|c|c|c|c|}
\hline \multirow[b]{2}{*}{ Indicadores/Variáveis (notas) } & \multicolumn{5}{|c|}{ Estatística descritivas } \\
\hline & Média & Moda & $\begin{array}{l}\text { Desvio } \\
\text { padrão }\end{array}$ & Variância & Missing \\
\hline Indicador 1 - Meios de hospedagem & 7,88 & 8,00 & 1,60 & 2,55 & 02 \\
\hline Indicador 2 - Equipamentos de lazer e entretenimento & 5,99 & 6,00 & 2,56 & 6,57 & 03 \\
\hline Indicador 3 - Comércio em geral & 6,03 & 5,00 & 2,19 & 4,82 & 17 \\
\hline Indicador 4 - Comércio de artesanatos & 7,01 & 7,00 & 2,03 & 4,11 & 14 \\
\hline Indicador 5 - Servicos de higiene e limpeza & 7,72 & 10,00 & 1,94 & 3,75 & 02 \\
\hline Indicador 6 - Serviços de alimentação & 7,60 & 8,00 & 1,96 & 3,85 & 02 \\
\hline Indicador 7 - Passeios oferecidos & 5,57 & 5,00 & 3,16 & 10,01 & 23 \\
\hline Indicador 8 - Serviços de recepção, informação e guias de turismo & 6,50 & 8,00 & 2,89 & 8,35 & 12 \\
\hline Indicador 9 - Patrimônio histórico/cultural & 7,31 & 8,00 & 2,34 & 5,50 & 15 \\
\hline Indicador 10 - Manifestações populares (folclore) & 4,83 & 7,00 & 3,05 & 9,28 & 56 \\
\hline Indicador 11 - Entretenimentos/diversões diurnas & 6,71 & 5,00 & 2,52 & 6,36 & 07 \\
\hline Indicador 12 - Entretenimentos/diversões noturnas & 4,99 & 0,00 & 3,27 & 10,72 & 29 \\
\hline Indicador 13 - Abastecimento de água & 7,95 & 10,00 & 2,04 & 4,15 & 05 \\
\hline Indicador 14 - Pavimentação das ruas & 6,90 & 8,00 & 2,06 & 4,27 & 03 \\
\hline Indicador 15 - Sinalização urbana (do DETRAN) & 7,08 & 8,00 & 1,91 & 3,64 & 16 \\
\hline Indicador 16 - Sinalização turística & 5,95 & 8,00 & 2,83 & 8,03 & 13 \\
\hline Indicador 17 - Limpeza pública & 5,37 & 8,00 & 2,96 & 8,80 & 06 \\
\hline Indicador 18 - Segurança pública & 4,75 & 0,00 & 3,34 & 11,17 & 17 \\
\hline Indicador 19 - Meios de comunicação & 7,25 & 8,00 & 2,38 & 5,66 & 01 \\
\hline Indicador 20 - Meios de transportes inter-municipais/regionais/estaduais) & 7,19 & 8,00 & 2,00 & 4,04 & 42 \\
\hline Indicador 21 - Meios de transportes intra-urbano & 6,96 & 8,00 & 1,87 & 3,51 & 33 \\
\hline Indicador 22 - Acesso aos serviços bancários & 6,63 & 8,00 & 2,85 & 8,10 & 22 \\
\hline Indicador 23 - Aceitação de pagamentos (cartão crédito/cheques) & 7,68 & 10,00 & 2,22 & 4,94 & 14 \\
\hline Indicador 24 - Valor das diárias dos meios de hospedagem & 6,66 & 8,00 & 2,53 & 6,40 & 11 \\
\hline Indicador 25 - Preços dos serviços de alimentação & 5,97 & 5,00 & 2,66 & 7,10 & 03 \\
\hline Indicador 26 - Preços dos serviços de lazer e entretenimento & 5,91 & 8,00 & 2,38 & 5,70 & 27 \\
\hline Indicador 27 - Amenidades ambientais (beleza das praias/rios/lagoas) & 9,11 & 10,00 & 1,38 & 1,90 & - \\
\hline Indicador 28 - Coleta de lixo nas praias, rios, lagoas, mangues... & 6,60 & 8,00 & 3,10 & 9,62 & - \\
\hline Indicador 29 - Limpeza dos banheiros das praias/rios/lagoas... & 6,05 & 8,00 & 3,02 & 9,09 & 15 \\
\hline Indicador 30 - Distribuição dos esgotos próximos às praias/rios/lagoas... & 5,05 & 0,00 & 3,50 & 12,22 & 08 \\
\hline Indicador 31 - Aspecto visual das barracas/cadeiras ... das praias/rios/lagoas & 6,75 & 5,00 & 2,36 & 5,60 & 03 \\
\hline Indicador 34 - Qualificação dos profissionais (diretos) da atividade & 6,96 & 10,00 & 2,45 & 5,99 & 01 \\
\hline Indicador 35 - Qualificação das pessoas indiretamente envolvidas na atividade turística & 6,78 & 8,00 & 2,24 & 5,00 & 13 \\
\hline Indicador 36 - Receptividade & 7,99 & 10,00 & 1,96 & 3,86 & 08 \\
\hline Indicador 37 - Confiança & 7,39 & 8,00 & 1,90 & 3,61 & 10 \\
\hline Indicador 39 - Nota geral & 6,85 & 8,00 & 2,03 & 4,13 & - \\
\hline
\end{tabular}

Fonte: Dados da pesquisa.

Nota: Os Indicadores 32, 33, 38, 40 a 54, não foram avaliados em termos de notas (entre 0 e 10). 
O "Indicador 12 - Entretenimentos/diversões noturnas", embora tenha registrado 29 missing, quantidade menor que a dos indicadores anteriores, apresentou nota média semelhante, 4,99. Ademais, a moda 0,00 chama a atenção e ratifica que o visitante de llhéus se defronta com estruturas e serviços inadequados para se divertir à noite.

O "Indicador 26 - Preços dos serviços de lazer e entretenimento", com nota média de 5,91 e 27 missing, apresentou situação semelhante ao anterior. Estes resultados atestam que para o turista, os preços são considerados altos e não condizentes com a qualidade dos produtos e serviços oferecidos. De toda forma, a moda $(8,00)$ ratifica que, em relação a entretenimento, a questão menos grave é o preço.

Dos indicadores considerados nas análises econométricas e com maiores notas, alguns casos presentes na Tabela 2 devem ser evidenciados. Destaca-se que o "Indicador 27 - Amenidades ambientais" foi avaliado por todos os entrevistados (não apresentando nenhum missing) e obteve moda 10,00. A maior nota média, 9,11, foi atribuída a este item da oferta turística (representativa por apresentar a menor variância verificada entre os indicadores), ou seja, com base em todas as estimativas, os entrevistados consideraram as belezas das praias, rios, lagoas, mangues etc. o melhor atrativo turístico de llhéus.

O "Indicador 36 - Receptividade da população", exibiu a segunda maior nota média, 7,99. Sem dúvida o carisma e a alegria atraem e fortalecem o desenvolvimento da atividade turística baiana.

Seguindo, em ordem de importância, ressaltam-se as notas médias dos itens, "Indicador 13 - Abastecimento de água" (7,95), "Indicador 1 - Meio de hospedagem" (7,88 ) e "Indicador 5 - Serviços de higiene e limpeza" (7,72). Os resultados encontrados para estes três indicadores são justificados pelo período 
de realização da pesquisa. $\mathrm{Na}$ baixa estação, geralmente, não surgem problemas com relação à distribuição de água, dada a reduzida presença de turistas. Como evidenciado, os visitantes pesquisados, em sua maioria, encontravam-se em meios de hospedagem de médio e grande portes, especificamente nos resorts (Anexo D), os quais oferecem estrutura e serviços qualificados.

Dos indicadores considerados nas análises, e com menores notas, alguns casos, presentes na Tabela 2, chamam a atenção. A menor nota média foi registrada para o "Indicador 18 - Segurança pública" $(4,75)$. Durante as entrevistas, os visitantes reclamaram muito da inexistência de vigilância nas ruas e nos pontos turísticos ou da forma de abordagem dos policias encontrados durante o percurso até a cidade de llhéus. No entanto, as pessoas questionadas ressaltaram que nos meios de hospedagem se sentiam mais seguras, revelando que a segurança financiada pela iniciativa privada tem configurado uma alternativa para alguns estabelecimentos hoteleiros do município.

A segunda menor nota média foi atribuída ao "Indicador 30 Distribuição das redes de esgotos próxima às praias, rios, lagoas, mangues e etc." $(5,05)$. Os turistas declararam ter informações sobre a poluição existente no local, muitas vezes camuflada quando próxima aos médios e grandes estabelecimentos. Outros entrevistados, ao percorrerem a cidade, depararamse com esgotos "a céu aberto" até mesmo nas praias do centro ou nos mangues localizados na entrada do município de llhéus.

Na seqüência das piores notas médias, com críticas significativas, surge o "Indicador 17 - Limpeza pública", (5,37), "Indicador 7 - Passeios oferecidos" $(5,57)$ e o "Indicador 16 - Sinalização turística" $(5,95)$.

Segundo os próprios visitantes, no conjunto, o turismo de llhéus parece se encontrar dentro de padrões aceitáveis. O "Indicador 39 - Nota geral" 
(avaliação geral ou satisfação total), que procurou avaliar a atividade turística como um todo, alcançou nota média de 6,85. Na escala entre zero e 10, esta média não apresenta nível fortemente reprovável. Entretanto, cabe frisar a relação que essa avaliação possui com o período da pesquisa (baixa temporada), de pequena procura e grande oferta, trazendo vantagens como preços reduzidos e melhores serviços (principalmente por parte dos meios de hospedagens e demais estabelecimentos de médio e grande portes). Mesmo assim, as notas indicam que a atividade necessita de investimentos capazes de ampliar a capacitação da estrutura turística e a satisfação dos visitantes de Ilhéus. Contudo, para compreender melhor a avaliação realizada, faz-se necessário descrever e relacionar características da visita e das pessoas que compuseram a amostra utilizada.

\subsection{Características do turistas entrevistados e informações adicionais sobre a viagem}

As características do turista e demais informações adicionais sobre a viagem são de fundamental importância para o desenvolvimento do turismo ilheense. Além de justificarem as avaliações sobre a estrutura turística, origem, estado civil, faixa etária, grau de instrução, nível de renda, meio de transporte (de deslocamento até o município), influência e motivo da viagem contribuem para a adequação da oferta do "produto llhéus" ao perfil e expectativas de sua demanda.

Em relação ao estado de origem do visitante ilheense (Anexo D) a pesquisa revelou que não houve um local que se destacasse dos demais. Do total dos turistas entrevistados, 23,2\% eram da Bahia, 20\% de Minas Gerais, $19,2 \%$ do Distrito Federal e $16 \%$ de São Paulo. Sem dúvida, a relativa proximidade com essas unidades federativas e a ausência de litorais em seus territórios tem reforçado essa procura. 
Através da Figura 1 é possível conhecer o estado civil dos turistas abordados em llhéus. As pessoas que estavam visitando o município eram, em sua maioria, casadas (cerca de 65,6\%), e, como observado durante as entrevistas, grande parte estava acompanhada do cônjuge. Essa realidade condiz com o período da pesquisa, de baixa estação, em que a maioria dos visitantes buscava junto com a família uma viagem tranquila, sem euforias. Ademais, Ilhéus recebeu $21,6 \%$ de solteiros e apenas $7,2 \%$ de desquitados e $4 \%$ de viúvos (Anexo D).

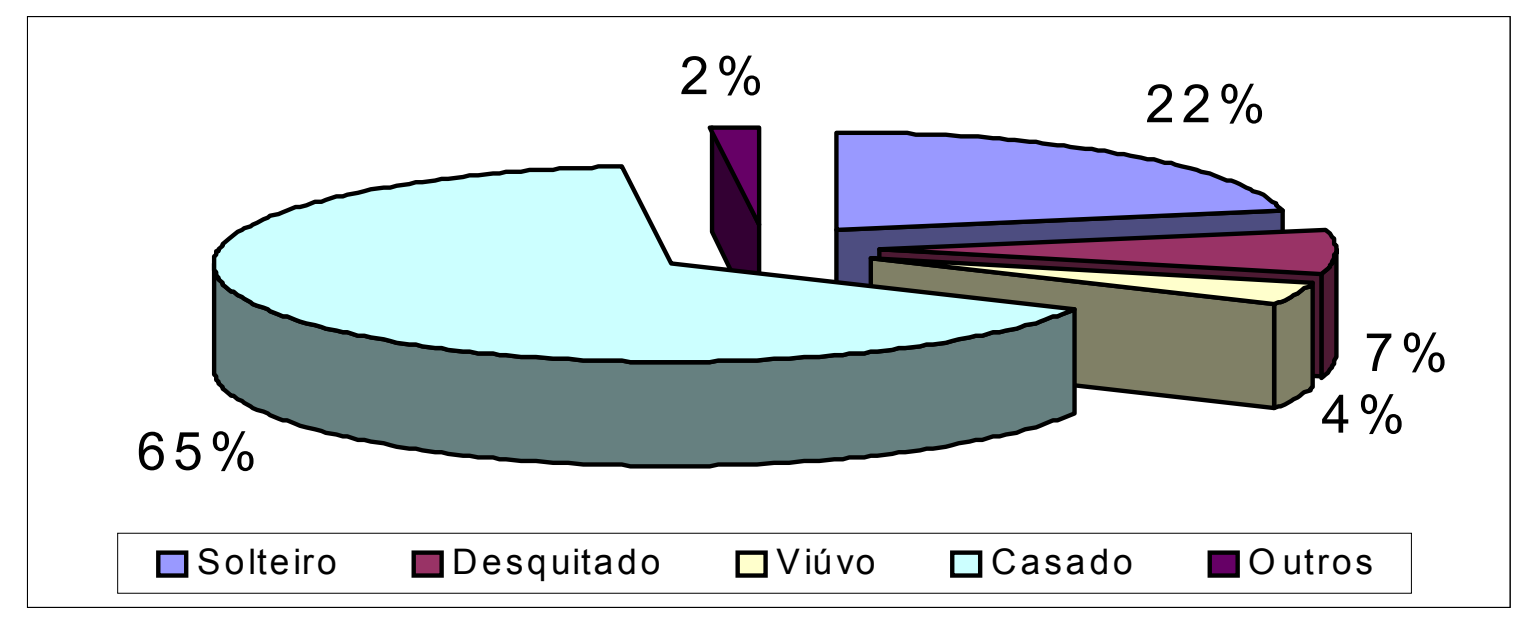

Figura 1 - Estado civil do turista do município de llhéus (BA).

Fonte: Dados da pesquisa.

Observando a idade dos visitantes de llhéus, através da Figura 2, verifica-se maior participação de duas categorias de faixa etária. Cerca de $37,6 \%$ do total dos turistas tinham entre 36 e 50 anos (Anexo D). Na faixa de 26 a 35 anos, encontravam-se $30,4 \%$ dos entrevistados. No período, os adolescentes, pessoas inseridas na faixa abaixo dos dezoito anos e os idosos, indivíduos com mais de 60 anos, foram minorias. O primeiro grupo não chegou a $2 \%$, e o segundo correspondeu a $5 \%$ dos turistas no município. Contudo, é 
preciso ressaltar que mais da metade $(56,8 \%)$ dos visitantes ilheenses eram de adultos com idade acima de 36 anos.

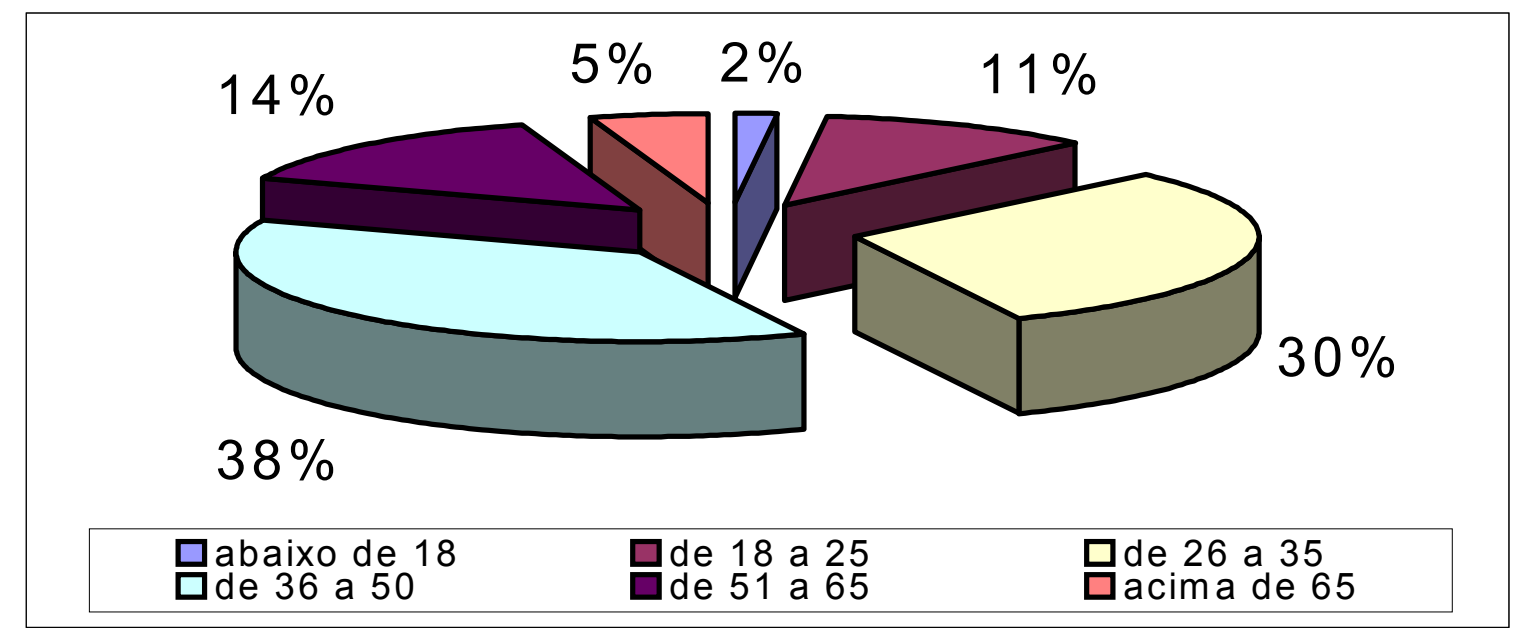

Figura 2 - Faixa etária (em anos) do turista do município de llhéus (BA). Fonte: Dados da pesquisa.

Na Figura 3 apresenta-se o grau de instrução do turista presente em Ilhéus (Anexo D); 56,8\% dos questionados disseram já possuir o nível superior, diferença "gritante" em relação aos demais. Do total abordado, 17,6\% disseram ter o segundo grau completo, $10 \%$ o curso técnico e apenas $2,4 \%$ o primeiro grau incompleto. Estes resultados podem indicar que o visitante vem ao município com expectativas de se deparar com um turismo bem estruturado, com serviços e produtos específicos. 


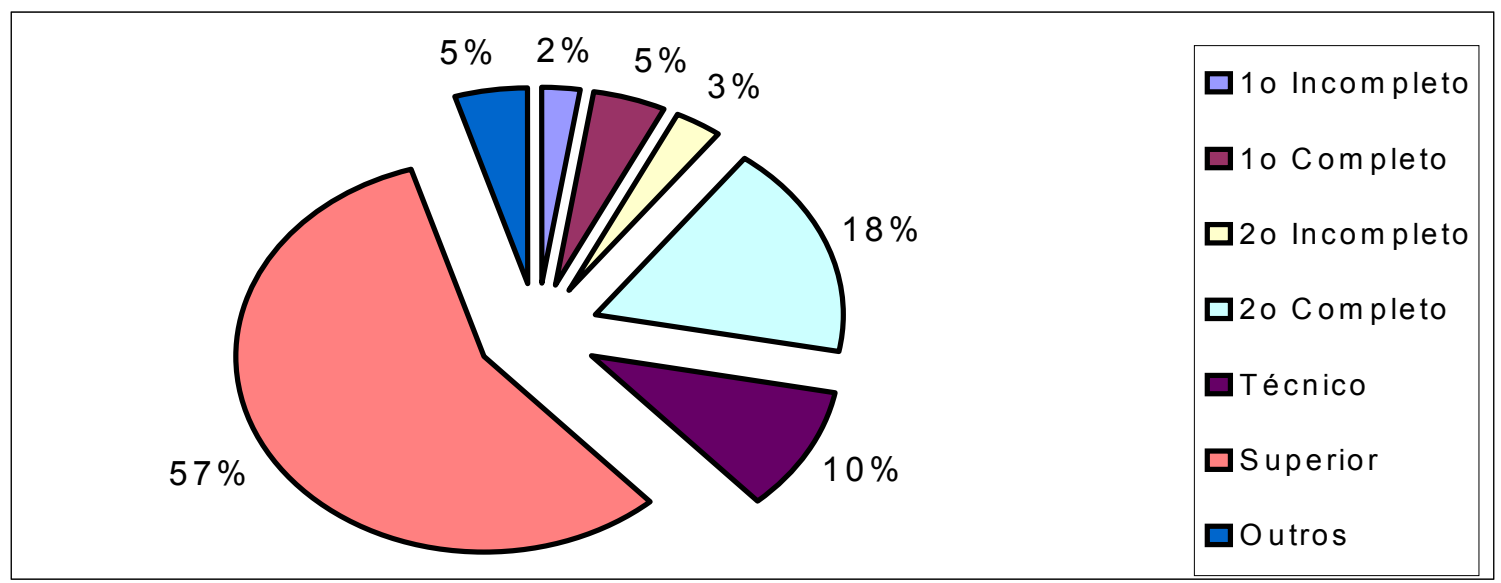

Figura 3 - Nível de instrução do turista do município de llhéus (BA).

Fonte: Dados da pesquisa.

Com relação à renda (Anexo $D$ ) verifica-se que o rendimento dos visitantes de llhéus não é tão baixo. A faixa entre $R \$ 1.511,00$ e $R \$ 2.214,00$, foi a mais registrada, por cerca de $17,6 \%$ dos entrevistados. As faixas de renda entre $R \$ 756,00$ a $R \$ 1.359,00$, entre $R \$ 2.266,00$ a $R \$ 2.869,00$ e com renda acima de $\mathrm{R} \$ 5.135,00$, cada uma com aproximadamente $13 \%$ dos visitantes abordados, foram também bastante selecionadas. De certa forma, aproximadamente $70 \%$ dos turistas que visitavam llhéus possuíam renda maior que $\mathrm{R} \$ 1.500,00^{42}$. Esse resultado é condizente com os níveis de instrução, observados anteriormente, e reforça a questão sobre o perfil do turista local, que deve ser observado durante o planejamento da atividade, adequando sua estrutura às necessidades específicas dos consumidores.

As características da viagem do grupo entrevistado trazem informações que também justificam as análises sobre os indicadores da estrutura do turismo ilheense. Como citado, alguns turistas tiveram dificuldades em avaliar os meios de transportes do miunicípio por não terem usufruído desses recursos. A maioria dos viajantes foi a llhéus de avião $(47,2 \%)$ ou

\footnotetext{
${ }^{42}$ Ou 10 salários mínimos (SM), dado que na época da pesquisa o SM era de $\mathrm{R} \$ 151,00$.
} 
veículo próprio (37,6\%), conforme evidenciado pela Figura 4 (Anexo D). Durante a pesquisa de campo, esses entrevistados revelaram depender dos transportes de onde estavam hospedados. Seguramente, o tipo de estabelecimento hoteleiro escolhido e o nível de renda desses turistas reforçam tal quadro. A participação de $15 \%$ dos visitantes que utilizaram ônibus como meio de transporte para chegar a llhéus deve-se ao número de excursões, principalmente de turistas da "melhor idade" (ou "maior idade") encontrados no período.

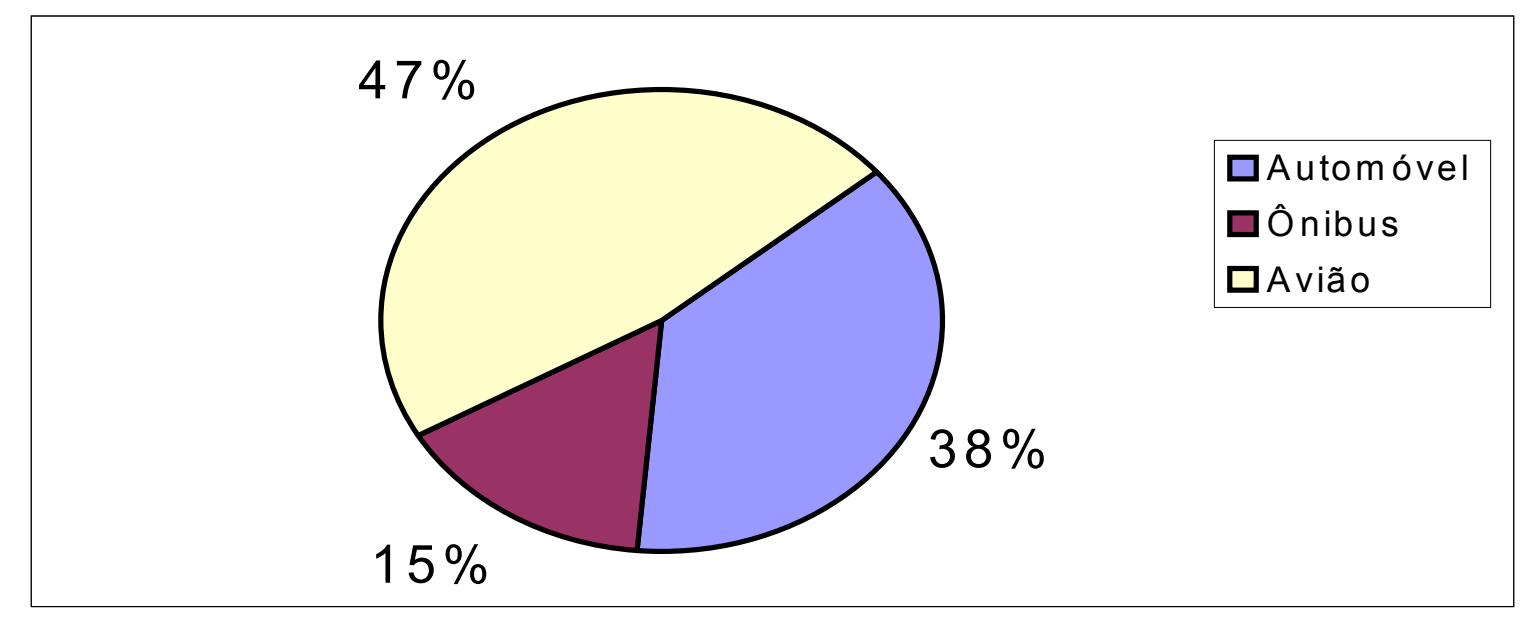

Figura 4 - Meios de transportes utilizados pelo turista em seu deslocamento até o município de llhéus (BA).

Fonte: Dados da pesquisa.

Observa-se um certo amadorismo da indústria turística quando se identifica, através da Figura 5 (Anexo D), a importância relativa dos fatores que influenciaram a ida do turista a llhéus. Do lado da oferta, chama a atenção a pequena participação e a influência que exercem as agências de viagens (8\%), propagandas/publicidade $(4 \%)$ e a Internet $(4 \%)$ na tomada de decisão do visitante na escolha do destino llhéus. A maioria dos entrevistados veio a llhéus 
porque já conhecia o município (42,4\%), e, do total dos abordados, 30,4\% foram influenciados pelos comentários de parentes e amigos. Esses números ressaltam os seguintes aspectos: a falta de profissionalismo na venda do "produto Ilhéus; a "força/poder" da imagem sobre o turismo, que é transmitida através da chamada propaganda "boca-a-boca", e a importância da satisfação do turista na escolha de retorno ao local.

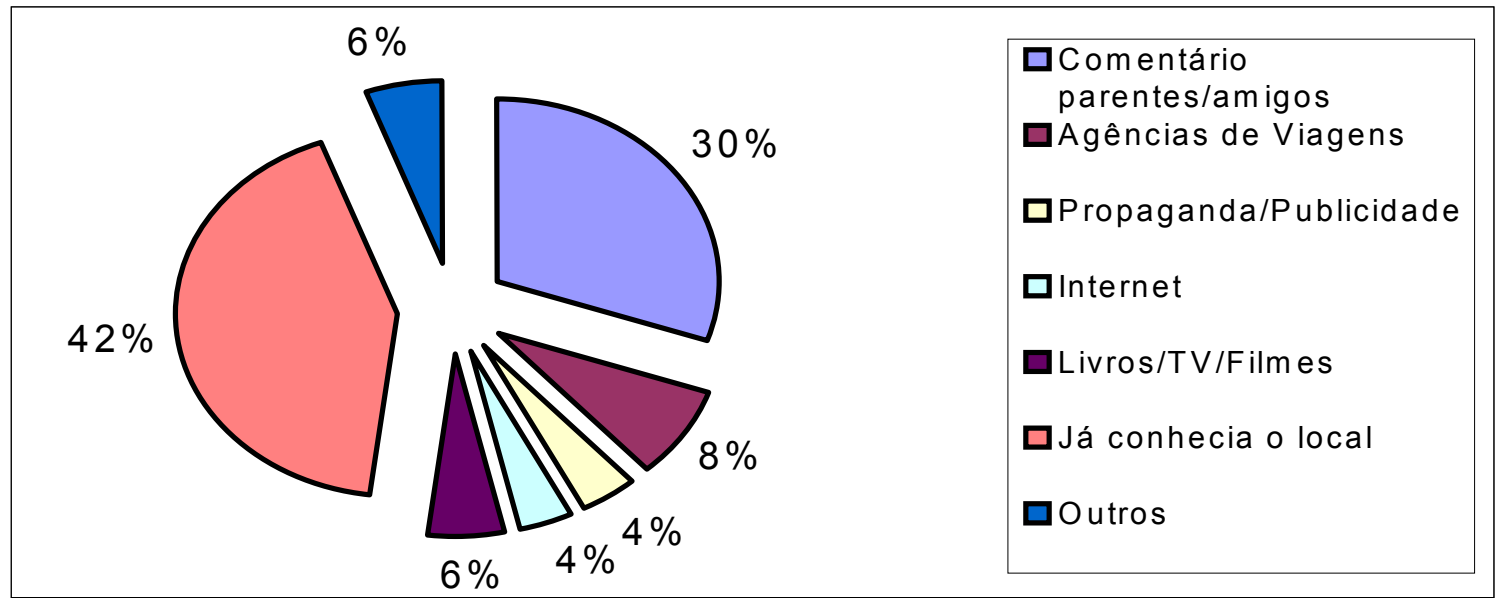

Figura 5 - Fatores que influenciaram a vinda do turista ao município de llhéus (BA).

Fonte: Dados da pesquisa.

Na Figura 6 (Anexo D) identificam-se os motivos pelos quais o turista vai a llhéus. Reduzida proporção das pessoas que escolhem esse destino tem como objetivo visitar parentes/amigos $(11,2 \%)$ ou o turismo de negócios $(4,8 \%)$. O fator passeio/lazer foi responsável por $81,65 \%$ da presença dos turistas no município. Portanto, a grande maioria dos visitantes ilheenses espera encontrar estrutura inerente ao turismo de passeio/lazer. Assim, a satisfação desses turistas está relacionada à capacidade ou qualificação dos serviços e equipamentos de entretenimentos/diversões, manifestações populares 
(folclore), serviços de guias, passeios oferecidos e patrimônio histórico/cultural, principalmente. No entanto, as notas médias desses indicadores sugerem que o visitante não se encontra bastante satisfeito. Todavia, as amenidades ambientais e a receptividade da população ilheense, com notas médias de 9,11 e 7,99, respectivamente, parecem ter conquistado o turista local, que pretende retornar $(94,4 \%)$ e recomendar $(94,4 \%)$ a outras pessoas uma visita a llhéus (Anexo D).

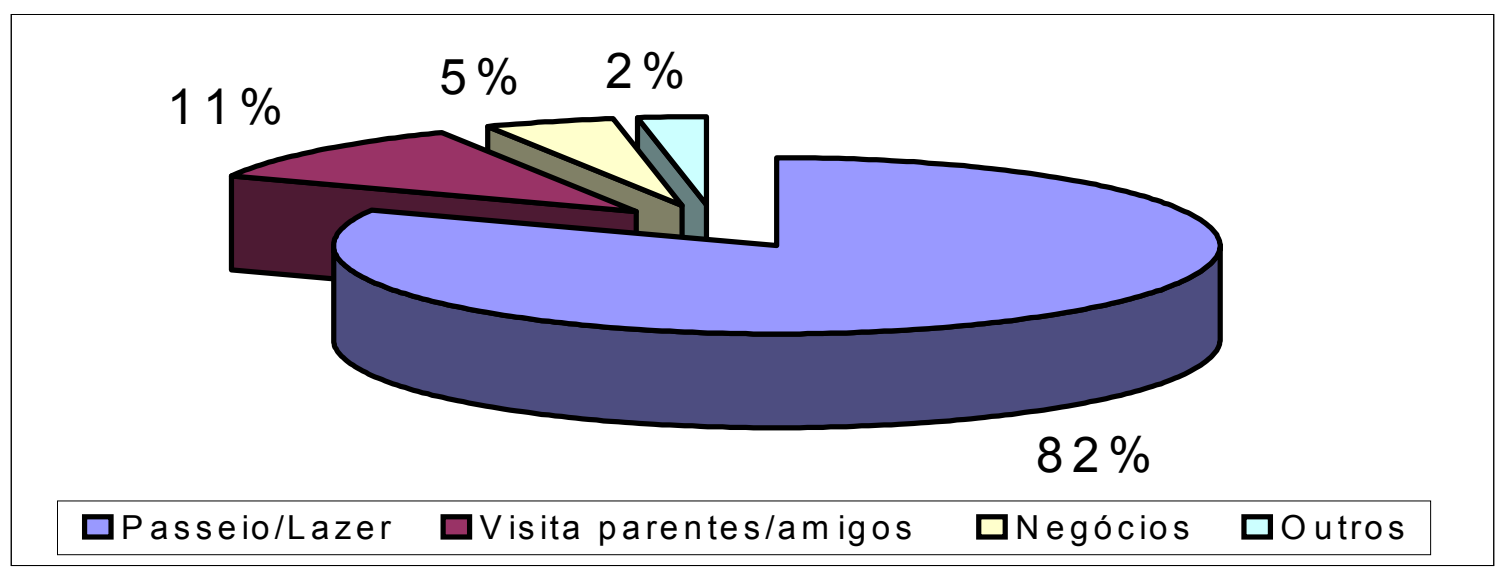

Figura 6 - Fatores que motivaram a vinda do turista para o município de llhéus (BA).

Fonte: Dados da pesquisa.

Por certo, as informações sobre as características/perfil do turista e sua viagem auxiliarão nas análise posteriores dos modelos desenvolvidos. Origem, estado civil, faixa etária, nível de instrução, nível de renda, meio de transporte utilizado no deslocamento, meio de hospedagem, influência e motivo da viagem são variáveis que influenciam a avaliação dos visitantes sobre a qualidade da estrutura turística de determinado local. Consequentemente, para compreensão das estimativas dos parâmetros dos modelos, particularmente 
das análises fatorial e de regressão, os dados apresentados nesta seção são de grande utilidade.

\subsection{Resultados da análise fatorial}

A fim de reduzir o número de variáveis, nesta pesquisa aplicou-se a análise fatorial, pelo método dos componentes principais. Para tanto, utilizou-se a matriz $125 \times 30$, referente às 30 variáveis (indicadores avaliados por meio de notas) e 125 observações (número de turistas entrevistados). Por default, via rotação varimax, com 10 interações, foram extraídos sete (7) fatores, por possuírem raízes características (eigenvalue) maiores que 1. Segundo a Tabela 3 , esses fatores captaram $68 \%$ da variância total dos 30 indicadores da estrutura turística de llhéus. A comunalidade indica a porção da variância da variável explicada pelo conjunto dos fatores (ou porção da variância que uma variável compartilha com todas as outras variáveis consideradas). Observa-se, nessa tabela, que a comunalidade de cada indicador varia entre 0,56315 e 0,74738; nesse caso, mais que $50 \%$ da variância das variáveis foram explicadas pelos sete fatores. As estatísticas Bartlett Test of Sphericity, $(2303,5912, \quad p<0,001)$ e Kaiser-Meyer-Olkin (KMO) $(0,89695)$ constataram, respectivamente, a conveniência do modelo fatorial e a adequacidade da amostra.

Outros resultados e estimativas trazem informações fundamentais da relação entre as variáveis e os fatores extraídos. Da matriz rotacionada dos fatores (Tabela 3), consideraram-se apenas as cargas fatoriais com magnitudes acima de 0,60 , as quais estão destacas em negrito. Dessa forma, as variáveis que apresentaram cargas fatoriais menores que 0,60 não foram levadas em conta, ou seja, como observado na Tabela 4, apenas as variáveis que apresentaram cargas fatoriais maiores que 0,60 foram consideradas na composição e interpretação dos fatores. Por fim, cada fator foi nomeado de acordo com as características dessas variáveis. 
Tabela 3. Matriz rotacionada: cargas fatoriais e comunalidades dos 30 indicadores (variáveis) relacionadas à estrutura turística do município de llhéus (BA).

\begin{tabular}{|c|c|c|c|c|c|c|c|c|}
\hline \multirow{2}{*}{$\begin{array}{c}\text { Variáveis/ } \\
\text { Cargas fatoriais }\end{array}$} & \multicolumn{8}{|c|}{ Cargas fatoriais } \\
\hline & Fator 1 & Fator 2 & Fator 3 & Fator 4 & Fator 5 & Fator 6 & Fator 7 & $\begin{array}{l}\text { Comu- } \\
\text { nalidade }\end{array}$ \\
\hline Indicador 1 - Meios de hospedagem & 0,21327 & 0,42027 & 0,18322 & 0,38373 & 0,50104 & $-0,09274$ & 0,09601 & 0,67179 \\
\hline Indicador 2 - Equipamentos de lazer/entretenimento & 0,44414 & 0,48269 & 0,02771 & 0,02470 & 0,44975 & 0,27787 & 0,04435 & 0,71308 \\
\hline Indicador 3 - Comércio em geral & 0,22076 & 0,40937 & 0,02944 & 0,37670 & 0,46575 & 0,30990 & 0,06109 & 0,67585 \\
\hline Indicador 4 - Comércio de artesanatos & 0,03681 & 0,08714 & 0,18806 & 0,02296 & 0,75976 & 0,13530 & 0,12304 & 0,65460 \\
\hline Indicador 5 - Serviços: higiene e limpeza & 0,28210 & 0,43959 & 0,23568 & 0,50896 & 0,38320 & 0,09537 & 0,02010 & 0,74376 \\
\hline Indicador 6 - Serviços de alimentação & 0,29394 & 0,27543 & 0,25918 & 0,34351 & 0,55783 & 0,09767 & 0,03145 & 0,66914 \\
\hline Indicador 7 - Passeios oferecidos & 0,21013 & 0,49750 & 0,61771 & $-0,00466$ & 0,17454 & 0,15977 & 0,07974 & 0,73560 \\
\hline Indicador 8 - Serviços de recepção/informação/guias & 0,29777 & 0,61474 & 0,39437 & 0,21748 & 0,12932 & 0,05823 & $-0,05324$ & 0,69234 \\
\hline Indicador 9 - Patrimônio histórico e cultural & 0,11569 & 0,80001 & 0,06051 & 0,13191 & 0,16885 & 0,09715 & 0,18700 & 0,74738 \\
\hline Indicador 11- Entretenimento/diversões diurnas & 0,33178 & 0,62348 & 0,28104 & 0,23505 & 0,18424 & 0,05500 & 0,06346 & 0,67403 \\
\hline Indicador 13 - Abastecimento de água & 0,07336 & 0,16531 & 0,14905 & 0,75615 & 0,12616 & 0,08892 & 0,01700 & 0,65080 \\
\hline Indicador 14 - Pavimentação das ruas & 0,29714 & 0,13301 & 0,16045 & 0,73883 & 0,07600 & 0,02872 & 0,02913 & 0,68504 \\
\hline Indicador 15 - Sinalização (DETRAN) & 0,21983 & 0,04285 & 0,24552 & 0,40506 & 0,23223 & 0,37871 & -0.35384 & 0,59707 \\
\hline Indicador 16 - Sinalização turística & 0,31504 & 0,55883 & 0,38117 & 0,12976 & 0,13354 & 0,19788 & $-0,08427$ & 0,63776 \\
\hline Indicador 17 - Limpeza pública & 0,39056 & 0,36326 & 0,41228 & 0,28258 & $-0,00985$ & 0,27389 & $-0,09247$ & 0,61798 \\
\hline Indicador 18 - Segurança pública & 0,57194 & 0,31664 & 0,02080 & 0,19408 & 0,11918 & 0,37352 & $-0,29104$ & 0,70390 \\
\hline Indicador 19 - Meios de comunicação & $-0,00108$ & 0,14754 & 0,01982 & 0,01403 & 0,25132 & 0,69109 & $-0,00494$ & 0,56315 \\
\hline Indicador 22 - Acesso: serviços bancários & $-0,00103$ & 0,31259 & 0,42937 & 0,15534 & $-0,13804$ & 0,54861 & 0,30473 & 0,71909 \\
\hline Indicador 25 - Preços dos serviços de alimentação & 0,52932 & $-0,05892$ & 0,21289 & 0,09599 & 0,12878 & 0,54015 & 0,12537 & 0,66225 \\
\hline Indicador 27 - Amenidades ambientais (beleza das praias, rios, lagoas ...) & 0,25922 & 0,13376 & 0,06509 & 0,06460 & 0,21156 & 0,12289 & 0,76301 & 0,73554 \\
\hline Indicador 28 - Coleta de lixo nas praias, rios, lagoas, mangues... & 0,73108 & 0,31566 & 0,21332 & 0,21030 & 0,08680 & 0,09356 & 0,06338 & 0,74415 \\
\hline Indicador 29 - Limpeza dos banheiros das praias, rios, lagoas... & 0,67843 & 0,25927 & 0,17490 & 0,31839 & 0,13268 & $-0,11673$ & 0,21373 & 0,73636 \\
\hline Indicador 30 - Distribuição das redes de esgotos próximos às praias/rios ... & 0,70956 & 0,24045 & 0,20686 & 0,19697 & 0,08215 & $-0,01221$ & $-0,01520$ & 0,65001 \\
\hline Indicador 31 - Aspecto visual das barracas, cadeiras ... das praias/rios... & 0,72976 & 0,10907 & 0,23330 & 0,00251 & 0,21920 & 0,06032 & 0,29105 & 0,73528 \\
\hline Indicador 34 - Qualificação profissionais diretamente envolvidos na ativ. & 0,36978 & 0,33125 & 0,37065 & 0,21882 & 0,43357 & 0,20208 & $-0,03972$ & 0,66213 \\
\hline Indicador 35 - Qualificação das pessoas indiretamente envolvidas na ativ. & 0,30539 & 0,24020 & 0,54083 & 0,19698 & 0,43412 & 0,15856 & $-0,02755$ & 0,69662 \\
\hline Indicador 36 - Receptividade & 0,11769 & 0,30711 & 0,65527 & 0,23656 & 0,12394 & $-0,24165$ & 0,14300 & 0,68772 \\
\hline Indicador 37 - Confiança & 0,15206 & 0,15589 & 0,68798 & 0,19433 & 0,18562 & 0,14513 & $-0,01191$ & 0,61417 \\
\hline \% da variância explicada (pelo fator) & 42 & 5,3 & 4,8 & 4,6 & 4,4 & 3,7 & 3,5 & \\
\hline
\end{tabular}

Fonte: Dados da pesquisa.

Os indicadores 10,12, 20, 21 e 26 foram extintos da análise fatorial por apresentarem quantidades de missing superiores a $20 \%$ (25

respostas inexistentes/ausentes), e os Indicadores 32, 33, 38, 40 a 54, não foram avaliados em termos de notas (entre 0 e 10). 
Tabela 4. Indicadores da estrutura turística e respectivas cargas fatoriais: relação dos estoques de capitais do município de llhéus (BA).

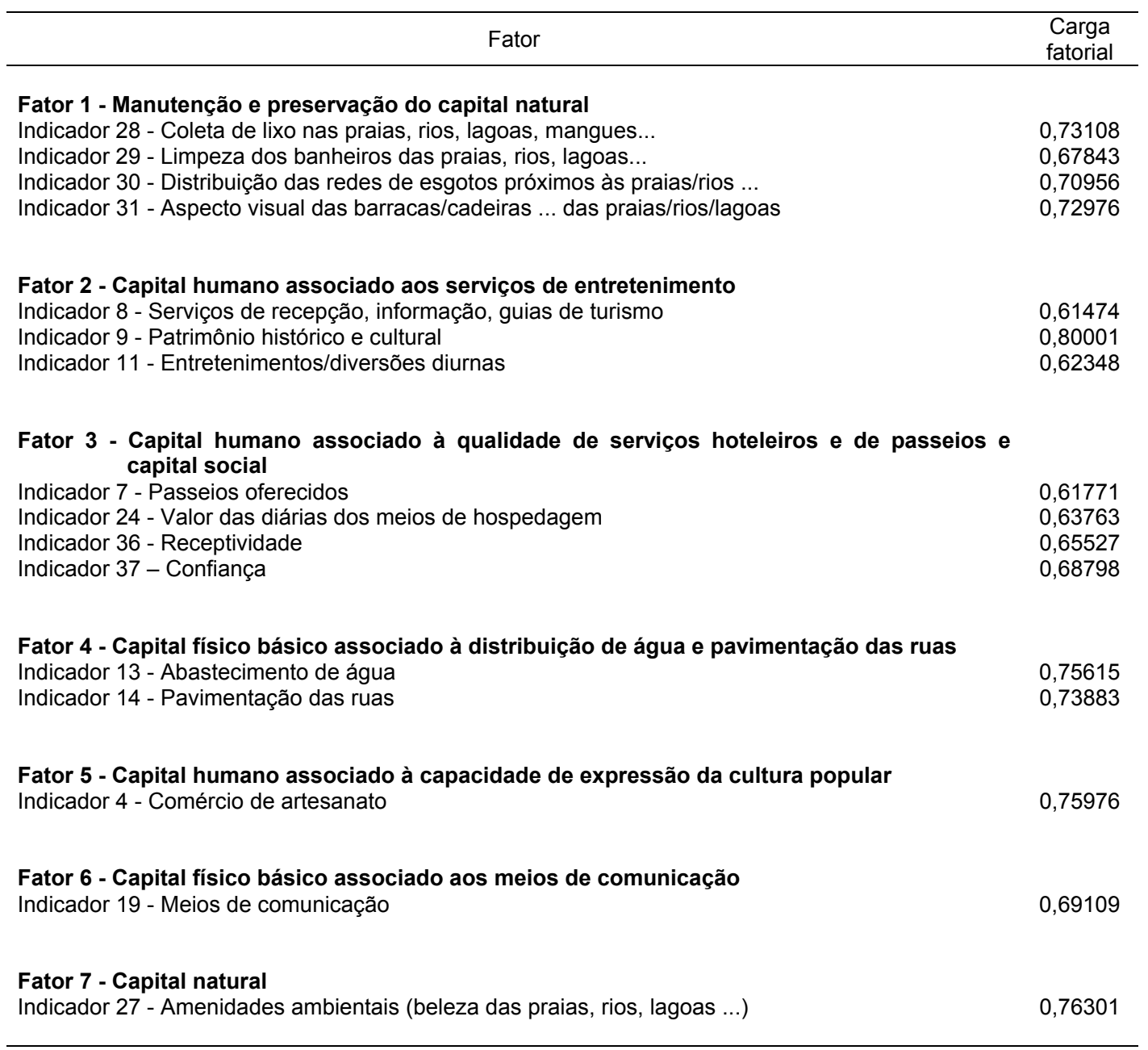

Fonte: Dados da pesquisa.

Os fatores foram, então, rotulados conforme apresentados na Tabela 4. O Fator 1 - Manutenção e preservação do capital natural explica $42 \%$ da variância total observada na amostra e foi composto por quatro indicadores: coleta de lixo, limpeza dos banheiros, distribuição das redes de esgotos e aspecto visual das barracas/cadeiras ..., todos relativos às praias, rios, lagoas, mangues etc. 
O Fator 2 - Capital humano associado aos serviços de entretenimento, responsável por $5,3 \%$ da variância dos dados, agregou três indicadores: serviços de recepção, informação/guias de turismo, patrimônio histórico/cultural e entretenimentos/diversões diurnas.

O Fator 3 - Capital humano associado à qualidade de serviços hoteleiros e de passeios e capital social respondeu por $4,8 \%$ da variância total, composto pelos indicadores: passeios oferecidos, valor das diárias dos meios de hospedagem, receptividade e confiança nos nativos.

\section{O Fator 4 - Capital físico básico associado à distribuição de} água e pavimentação das ruas, responsável por $4,6 \%$ da variância, agregou os indicadores: abastecimento de água e pavimentação das ruas.

O demais fatores apresentaram, cada um, relação com apenas um indicador da estrutura turística. O Fator 5 - Capital humano associado à capacidade de expressão da cultura popular, que explicou $4,4 \%$ da variância, está relacionado ao indicador comércio de artesanato; O Fator 6 Capital físico básico associado aos meios de comunicação, vinculado à variável meios de comunicação; e o Fator 7 - Capital natural, identificado pelo indicador amenidades ambientais (beleza das praias, rios, lagoas, mangues etc.). Os dois últimos fatores explicaram apenas 3,7\% e 3,5\% da variância dos dados, respectivamente.

\subsection{Resultados da regressão múltipla}

$\mathrm{Na}$ Tabela 5 descrevem-se os resultados referentes às estimativas dos parâmetros e testes estatísticos do modelo de regressão múltipla que foi estimado pelo método dos Mínimos Quadrados Ordinários (MQO). Neste, a variável dependente foi a nota geral (avaliação geral ou satisfação total) do visitante para a atividade turística de llhéus; os sete fatores ortogonais (ou escores fatoriais extraídos das notas atribuídas aos indicadores da estrutura 
turística), as características do turista e da viagem foram as variáveis independentes dos modelos. Os escores fatoriais foram utilizados para evitar o efeito multicolinearidade devido a possibilidade de correlação entre as variáveis. Dessa forma, a Tabela 5 apresenta a influência das variáveis independentes na nota média geral (avaliação média geral ou satisfação total) do visitante para a atividade turística de llhéus.

Foi escolhido o modelo que apresentou o maior número de variáveis significativas, a um dado nível de significância. A comparação entre modelos com variáveis dependentes e independentes distintas (com e sem transformação logarítmica) foi realizada com base nos valores dos testes "t de Student" e não com base no $R^{2}$. Assim, o modelo linear foi o escolhido por apresentar o maior número de variáveis significativas (Anexo $\mathrm{E}$ ).

O modelo de regressão linear estimado apresentado na Tabela 5 e eq. (21) descreve os coeficientes e os níveis de significância dos parâmetros. No que diz respeito aos fatores (extraídos das notas atribuídas aos indicadores da estrutura turística), todos obtiveram sinais positivos, de acordo com o esperado, e foram estatisticamente significativos. 
Tabela 5. Coeficientes, valores de "t" e estatística "F" do modelo de regressão linear.

\begin{tabular}{|c|c|c|}
\hline \multirow{2}{*}{ Variáveis explicativas } & \multicolumn{2}{|c|}{ Modelo linear } \\
\hline & Coeficiente de regressão & Teste " $t$ " de Student \\
\hline Constante & 7,596693 & 13,330 \\
\hline$F_{1}$ & 0,658704 & 6,405 \\
\hline$F_{2}$ & 1,092313 & 10,629 \\
\hline$F_{3}$ & 0,723826 & 7,141 \\
\hline$F_{4}$ & 0,327893 & 3,093 \\
\hline$F_{5}$ & 0,674487 & 6,434 \\
\hline$F_{6}$ & 0,405196 & 4,031 \\
\hline$F_{7}$ & $0,169040^{\star *}$ & 1,703 \\
\hline$X_{1}$ & $-0,185808^{* *}$ & $-1,739$ \\
\hline$X_{2}$ & $-0,050804^{* *}$ & $-1,864$ \\
\hline$X_{3}$ & $0,000059^{\mathrm{NS}}$ & 0,003 \\
\hline$X_{4}$ & $0,058097^{\mathrm{NS}}$ & 0,733 \\
\hline$X_{5}$ &,$- 026508^{\mathrm{NS}}$ & $-0,314$ \\
\hline$X_{6}$ & $0,066547^{\mathrm{NS}}$ & 1,420 \\
\hline$X_{7}$ & $-0,122918^{N S}$ & $-1,401$ \\
\hline$R^{2}$ & 0,73548 & \\
\hline$R^{2}$ ajustado & 0,70181 & \\
\hline$F_{(14 ; 125)}$ & 21,84597 & \\
\hline
\end{tabular}

* Estatisticamente significativo a 5\%. ${ }^{* *}$ Estatisticamente significativo a $10 \%$. NS Estatisticamente não significativo. Os demais são estatisticamente significativos a 1\%. 
Com relação às características do visitante de llhéus, foram incluídos cinco indicadores na estimativa da regressão múltipla. A Tabela 5 mostra que as variáveis "idade" $\left(X_{1}\right)$ e "renda" $\left(X_{2}\right)$ apresentaram influência significativa, embora negativa, sobre a "nota média geral (avaliação média geral ou satisfação total) do visitante de llhéus". Porém, as variáveis "sexo" ( $\left.X_{3}\right)$, "grau de instrução" ( $\left.X_{4}\right)$ e "estado civil" ( $\left.X_{5}\right)$ não tiveram influência significativa sobre aquela variável independente.

As informações referentes à viagem dos turistas também foram inseridas na análise de regressão. Entretanto, os indicadores "influência da viagem" ( $\left.X_{6}\right)$ e "motivo da viagem" ( $\left.X_{7}\right)$ não apresentaram significância sobre a "nota geral (avaliação geral ou satisfação total) do visitante de llhéus".

$$
\begin{aligned}
Y= & \underset{(13,330)}{7,5967}+\underset{(6,405)}{0,6587 F_{1}}+\underset{(10,629)}{1,0923 F_{2}}+\underset{(7,141)}{0,7238 F_{3}}+\underset{(3,093)}{0,3279 F_{4}}+\underset{(6,434)}{0,6745 F_{5}}+ \\
& +\underset{(4,031)}{0,4052 F_{6}}+\underset{(1,703)}{0,1690^{* *}} F_{7}-\underset{(-1,739)}{0,1858^{* *}} X_{1}-\underset{(-1,864)}{0,0508^{* *}} X_{2}
\end{aligned}
$$

$$
R^{2}=0,73548, \quad \text { Teste } F \text { da regressão }=21,85^{*}
$$

Através da Tabela 5 e eq. $(10)^{43}$ pode-se analisar a importância (o peso) de cada fator e cada variável referente às características do turista na "nota geral média (avaliação geral média ou satisfação total) do visitante de Ilhéus". Observa-se, nessas tabela e equação, que todos os fatores registraram sinais positivos. Isso significa que a variação de uma unidade na nota registrada

\footnotetext{
${ }^{43}$ Os valores abaixo das estimativas dos parâmetros e entre parênteses referem-se aos valores da estatística "t". * Estatisticamente significativo a 5\%. ${ }^{* *}$ Estatisticamente significativo a 10\%. ${ }^{\mathrm{NS}}$ Estatisticamente não significativo. Os demais são estatisticamente significativos a $1 \%$.
} 
para os respectivos fatores resulta numa variação positiva na nota geral média. Os dois fatores com maiores pesos na avaliação geral média do turismo ilheense foram o "Fator 2 - capital humano associado aos serviços de entretenimento" e o "Fator 3 - capital humano associado à qualidade dos serviços hoteleiros e de passeios e capital social". Pode-se verificar, então como o capital humano e o capital social demonstram ser importantes na avaliação que o visitante faz da atividade turística de llhéus.

Os dois fatores com menores pesos foram o "Fator 4 - capital físico básico associado à distribuição de água e pavimentação das ruas" e o "Fator 7 capital natural". A presença do Fator 4 no modelo constata que a oferta de serviços básicos de caráter não-estritamente turístico tem peso na satisfação do visitante, embora contribua relativamente pouco na avaliação geral. O reduzido peso do Fator 7 pode ser explicado quando se observa a discrepância entre a média da nota que os visitantes atribuíram às "Amenidades Ambientais", o Indicador 27 e a média da nota geral atribuída ao turismo do município, o Indicador 39 (Ver Tabela 2). Verdadeiramente não são as belezas naturais que fizeram com que o visitante considerasse o turismo de llhéus dentro de padrões "aceitáveis" ou não fortemente reprováveis, distante de uma atividade turística de alto padrão.

Os indicadores referentes às características dos turistas trazem informações importantes. O sinal negativo do coeficiente de regressão da variável "faixa etária" $\left(X_{1}\right)$ aponta que à medida que aumenta a idade do visitante diminui, em média, a nota geral (ou piora a sua avaliação geral) do turismo ilheense. Da mesma forma, a variável "faixa de renda" $\left(X_{2}\right)$ revela que os turistas que possuem um nível de rendimento mais elevado atribuem, em média, menor nota geral ao turismo local. Este tendem a ser mais exigentes e, talvez por experiências anteriores de viagem, possuem uma avaliação mais rígida sobre a atividade de lazer. Portanto, os resultados podem indicar que os atrativos e serviços turísticos de llhéus podem não estar apropriados às 
necessidades dos seus consumidores, que em sua maioria são adultos e com níveis altos de renda (Anexo D). 


\section{CONCLUSÕES}

Um exame pormenorizado do turismo de llhéus permitiu identificar os fatores/estoques de capitais que têm ou não contribuído para o desenvolvimento da atividade. Nesse sentido, a avaliação da estrutura turística (através dos indicadores referentes ao capital físico, financeiro, humano, social e natural), as características dos turistas e de sua viagem auxiliam o planejamento, permitindo a ampliação da eficiência do setor.

Análises descritivas das variáveis relacionadas aos produtos e serviços turísticos, trazem informações importantes sobre o turismo de llhéus. Os 36 itens contemplados nesta pesquisa foram avaliados por meio de notas, num intervalo entre zero e dez. Em média, a nota geral (avaliação geral ou satisfação total) do turista foi de 6,85. Este valor pode indicar que a industria turística ilheense, no geral, é satisfatória, quando se considera a amplitude da avaliação estabelecida.

Os dados indicam as práticas culturais como a maior fragilidade do turismo de llhéus. O "Indicador - Manifestações populares" se destacou dos demais em termos de valores missing $(56)$ e nota média $(4,83)$ obtida. Estes resultados revelam que grande parte dos turistas optaram por não atribuir nota ou não avaliar este item, justificando durante a pesquisa de campo que considerava o folclore inexistente. Mesmo os entrevistados que avaliaram o indicador revelaram esperar muito mais do que lhes fora oferecido em termos de transmissão oral e visível do conjunto de crenças, mitos, contos, costumes e etc. do povo ilheense. 
De acordo com as notas atribuídas pelo visitante, o "Indicador Amenidades ambientais" representa o melhor atrativo turístico de llhéus. Além de ter sido analisado por todos os entrevistados (nenhum missing) com grande facilidade, registrou a maior nota média $(9,11)$, menor variância dentre todos os indicadores, cuja moda $(10,00)$ torna representativa. Localizado em área de Mata Atlântica e com $90 \mathrm{Km}$ de litoral, os resultados constatam que as belezas naturais das praias, rios, lagoas, mangues e etc. de llhéus tem atraído e conquistado os visitantes.

Das características dos turistas entrevistados, foi possível traçar um perfil da demanda. Em relação ao estado de origem do visitante, houve uma distribuição equivalente: $23,2 \%$ eram procedentes de outros municípios do interior da Bahia, $20 \%$ de Minas Gerais, $19,2 \%$ do Distrito Federal e $16 \%$ de São Paulo. A relativa proximidade deve ter reforçado a procura por esses estados. Como essas unidades territoriais não possuem litoral, as informações podem apontar e ratificar a importância que os recursos naturais, principalmente a praia, possui na escolha do destino llhéus.

Os dados revelam a inter-relação existente entre os indicadores estado civil e faixa etária dos turistas ilheenses. A maioria dos visitantes presentes no município, cerca de $65,6 \%$ era de casados e disse estar acompanhado pelo cônjugue. A faixa etária predominante, com $37,6 \%$, era de pessoas entre 36 a 50 anos. Mais da metade dos presentes $(56,85 \%)$ era de adultos com mais de 36 anos. Os indivíduos com idade inferior à 18 anos eram a minoria e não alcançaram $2 \%$ de participação. Portanto, como os turistas de Ilhéus, em sua maioria, são pessoas adultas, era de se esperar que também fossem casadas; geralmente faixa etária e estado civil são variáveis que se reforçam mutuamente.

A faixa de renda e o grau de instrução do visitante de llhéus também apresentaram inter-relação. Do total dos entrevistados, quase $70 \%$ disse 
receber, mensalmente, mais que $\mathrm{R} \$ 1.500,00$ (ou dez salários mínimos, da época da pesquisa). A faixa de renda entre $R \$ 1.511,00$ e $R \$ 2.214,00$ apresentou a maior participação, com 17,6\%. Este nível de rendimento é justificado quando se observa o nível de instrução dos turistas. A grande maioria dos respondentes $(56,8 \%)$ afirmou possuir curso superior; apenas $2,4 \%$ possuía $1^{0}$ grau incompleto. Dessa forma, pode-se dizer que, significativa parcela dos turistas de llhéus tem instrução boa e recebe salários mensais relativamente altos e compatíveis com sua escolaridade.

Das características da viagem dos turistas de llhéus, é importante ressaltar algumas informações. Com relação ao meio de transporte utilizado no deslocamento até o município, quase metade dos visitantes utilizou o avião $(47,2 \%)$ e outra porção significativa $(37,6 \%)$, o veículo próprio. Do total de entrevistados, poucos foram influenciados pelos meios tradicionais de venda ou distribuição dos produtos e serviços turísticos, como as agências de viagem (8\%) e propaganda/publicidade (4\%). Ademais, $81,6 \%$ dos turistas afirmaram que o fator passeio/lazer foi o que motivou a escolha do município de llhéus como roteiro de viagem.

A análise fatorial pelo método dos componentes principais resumiu as informações registradas para os 35 indicadores da estrutura turística de Ilhéus. As estatísticas Bartlett Test of Sphericity, $(2303,5912, p<0,001)$ e Kaiser-Meyer-Olkin (KMO) $\quad(0,89695)$ constataram, respectivamente, a conveniência do modelo fatorial e a adequacidade da amostra. Sete fatores foram extraídos e nomeados segundo as características das variáveis que os compuseram. O "fator 1 - Manutenção e preservação do capital natural" explicou $42 \%$ da variância dos dados, seguido pelo "fator 2 - Capital humano associado aos serviços de entretenimento", 5,3\%; do "fator 3 - Capital humano associado à qualidade de serviços hoteleiros e de passeios e capital social" , 
4,8\%; do "fator 4 - Capital físico básico associado à distribuição de água e pavimentação das ruas", 4,6\%; do "fator 5 - Capital humano associado à capacidade de expressão da cultura popular", 4,4\%; do "fator 6 - Capital físico básico associado aos meios de comunicação", 3,7\%; e o do "fator 7 - Capital natural", explicando $3,5 \%$ da variância total da amostra.

O modelo de regressão linear procurou avaliar a influência dos sete fatores, das variáveis referentes às características do turista e de sua viagem (variáveis explicativas) na nota geral (variável dependente). Os coeficientes de todos os fatores apresentaram sinais positivos (conforme o esperado) e estatisticamente significativos. Assim, os coeficientes revelaram que, quanto mais qualificada a estrutura turística, maior a nota geral (ou avaliação geral) do visitante de llhéus. O fator de maior importância (peso) na nota geral foi o "fator 2 - Capital humano associado aos serviços de entretenimento" e o fator de menos importância (peso) foi o "fator 7 - Capital natural".

As variáveis faixa etária e faixa de renda dos turistas apresentaram coeficientes negativos e estatisticamente significativos. Dessa forma, pode-se afirmar que à medida que a idade e a renda do visitante aumentam, a nota geral atribuída à atividade turística de llhéus diminui.

Em suma, as informações e análises sobre os indicadores da estrutura turística, características do visitante e de sua viagem indicam que a industria do turismo de llhéus carece de algumas mudanças e maior investimento nos estoques de capitais. Os produtos e serviços de entretenimento não correspondem às expectativas do turista, que, em sua grande maioria, vai ao município a passeio/lazer. Esses visitantes, mesmo satisfeitos com as belezas naturais locais, estão atentos à preservação desses recursos e também consideram itens não estritamente relacionados à atividade como, por exemplo, limpeza e segurança pública. Ademais, é preciso adequar a oferta, o "destino llhéus", ao perfil da demanda, composta por indivíduos 
adultos, instruídos e com níveis de renda relativamente elevados. Portanto, os resultados apontam que a eficiência da atividade, no período de baixa estação, depende da capacidade de investimento em capital humano e capital físico. Sugere-se que outras pesquisas sejam realizadas no período de alta estação, de forma que auxiliem o planejamento turístico ao longo de todo o ano, ampliando e mantendo a procura e o crescimento do setor. 
ANEXOS 


\section{ANEXO A - ALGUNS ESTUDOS SOBRE OS EFEITOS NA ECONOMIA DOS ESTOQUES DE CAPITAL SOCIAL}

\section{Itália: capital social, comunidade cívica e desenvolvimento regional}

Buscando compreender a diferença sócioeconômica entre o Norte e o Sul da Itália, a relação comunidade cívica e desenvolvimento regional foi minuciosamente analisada por Putnam (1996). Por certo, o desempenho das regiões italianas apresentou-se distinto ao longo dos anos, mas foi no decorrer do século XX que se ampliou o hiato Norte - Sul. Em meados dos anos 80 , por exemplo, o Norte possuía renda per capta cerca de $80 \%$ mais alta do que a do Sul.

As teorias do desenvolvimento pontuam vários fatores responsáveis pela desigualdade regional. Dentre outros aspectos os trabalhos citam a dependência centroperiferia, políticas públicas inadequadas, imperfeições de mercado, diferenças culturais. No caso da Itália, a literatura considera o subdesenvolvimento do Sul originado pelas desvantagens físicas, políticas (comerciais, fiscais e industrias) equivocadas, pobreza moral e carência de capital humano. Contudo, os dados e informações adquiridos nas regiões italianas revelam o papel essencial dos fatores sócioculturais no desempenho das economias locais. Não que toda explicação seja baseada num único fator, mas é preciso reconhecer que as tradições cívicas ajudam a explicar porque o Norte conseguiu reagir mais eficazmente do que o Sul aos desafios e oportunidades. Os resultados indicam que o civismo possui estreita relação com o desenvolvimento social e econômico, pois as regiões com maior participação cívica possuem melhores condições sanitárias e elevados índices de industrialização e, por isso, são as mais prósperas. As análises históricas vão mais além ao comprovarem que o civismo serve para prognosticar o desempenho das economias, mais do que as próprias variáveis geralmente utilizadas em análises econômicas.

"Apesar do turbilhão de mudanças, as regiões caracterizadas pela participação cívica no final do século $\mathrm{XX}$ são quase precisamente as mesmas onde as cooperativas, as associações culturais e as sociedades de mútua assistência eram mais abundantes no século XIX, e onde as associações comunitárias, as confrarias religiosas e as guildas haviam contribuído para o advento das repúblicas comunais do século XII. Essas regiões cívicas não eram especialmente adiantadas um século atrás, mas foram invariavelmente ultrapassando as regiões menos cívicas, seja em termos de desenvolvimento econômico ou de qualidade de governo..." (Putnam 1996, p.172)

Por certo, durante vários períodos, o Norte da Itália se sobressaiu ao lidar com o coletivo. As regras de reciprocidade e os sistemas de participação cívica corporificaram-se em 
confrarias, guildas, sociedades de mútua assistência, cooperativas, sindicatos e até clubes de futebol e grêmios literários. Esses vínculos cívicos horizontais propiciaram níveis de desempenho econômico e institucional muito mais elevados. "Nos anos 80 , o Norte também conquistara larga margem de superioridade em termos de capital físico e humano, o que é acentuado e em parte explicado pela antiga superioridade de seu capital social" (Putnam 1996, p.191)

No nível "micro" (econômico) também se observa que o civismo e o progresso econômico possuem forte relação; basta atentar-se para os "distritos industriais"1 do CentroNorte da Itália. As empresas ali presentes, como qualquer outra, buscam a eficiência e competem entre si. Porém, a característica marcante desses distritos é a combinação aparentemente contraditória de concorrência com cooperação, em todos os níveis. Nesse sentido, os mecanismos institucionais, as redes de associações privadas e organizações políticas propiciam às empresas infra-estrutura, serviços de assistência administrativos e financeiros, aquisição de matérias-primas, pesquisas e serviços sociais indispensáveis como treinamento profissional que, muitas vezes, isoladas não poderiam obter.

"Em geral considera-se que as normas de reciprocidade e os sistemas de participação cívica são a chave do sucesso dos distritos industriais, seja na Itália ou em outros países. Tais sistemas facilitam o fluxo de informações sobre os avanços tecnológicos, a capacidade creditícia de eventuais empresários, as qualificações de cada trabalhador e etc. ... O fundamental nesses distritos de pequenas indústrias, segundo a maioria dos observadores, é a confiança mútua, a cooperação social e o forte senso do dever cívico..." (Putnam 1996, p.170)

"Há algo na eficiência dos distritos industriais italianos, por exemplo, que é profundamente social, mas que se transforma em valor econômico, em acumulação, posto que se torna eficiência produtiva, comercial ou empresarial. É um tipo de recurso que se transforma em ativos intangíveis e que, por sua vez, se transforma em ativos bastantes tangíveis: riqueza social, renda, produção" (Sachs \& Lages 2001, p.5).

As associações de crédito rotativo, igualmente, são exemplos de como o capital social promove a cooperação voluntária. Essas associações são constituídas por indivíduos ou

1 Putnam (1996) toma emprestado o conceito de "distritos industriais" de Alfred Marshall, um dos fundadores da moderna ciência econômica. 
empresas que formam um fundo destinado, alternadamente, a cada componente. Exemplos desse tipo de associação são encontrados:

"Da Nigéria à Escócia, do Peru ao Vietnã, do Japão ao Egito, dos emigrantes antilhanos do leste dos Estados Unidos aos chicanos do oeste, dos iletrados aldeões chineses aos bancários e aos analistas econômicos da cidade do México, raro é onde não se tenha notícia das associações de crédito rotativo. Muitas sociedades norte-americanas de poupança e empréstimos começaram como associações de crédito rotativo". (Putnam 1996, p.177)

Esse sucesso e difusão das associações de crédito rotativo devem-se ao fato de estas estarem ligadas a cooperativas e outras formas de mútua assistência e solidariedade e às regras de reciprocidade e confiança, como componente básico do capital social. Por isso, Putnam (1996) citando Kenneth Arrow descreve:

"Praticamente toda transação comercial encerra um elemento de confiança ... pode-se muito bem afirmar que boa parte do atraso econômico no mundo se deve à falta de confiança... Nas regiões cívicas da Itália, à diferença de Nápoles, a confiança social sempre foi um elemento básico do ethos que sustentou o dinamismo econômico e o desempenho governamental..." (Putnam 1996, p.180)

\section{Tanzânia: capital social, participação social e renda das famílias}

Em estudo realizado na Tanzânia, por Narayan \& Prichett (1999), procurou-se consolidar a definição de capital social como algo acumulado que contribui para ampliar o produto e renda. Dados sobre capital social foram levantados sob diversas formas. Primeiro, registrou-se o número de grupos nos quais um indivíduo era membro. Em média, cada pessoa disse participar de 1,5 grupo, em sua maioria, de igrejas cristãs, partidos políticos, grupos de mulheres, grupos de fazendeiros e etc. As questões posteriores foram agrupadas em cinco categorias: heterogeneidade de parentesco dos membros, heterogeneidade da renda dos membros, funções do grupo, decisões tomadas pelo grupo e membros voluntários.

Os modelos testados por Narayan \& Prichett $(1999)^{2}$ foram estatisticamente significativos, e como variável dependente foram utilizados os gastos como proxy da renda, pela

\footnotetext{
2 Informações detalhadas sobre os modelos ver Narayan \& Prichett (1999). Em todo o trabalho o autor estima regressões buscando verificar a importância de algumas varáveis, medidas do Capital Social, e sua influência na renda, na atividade agrícola ..., testando em situações diversas.
} 
dificuldade de mensurar a renda dos autônomos. Os resultados encontrados revelaram forte associação entre o capital social e a renda familiar. As estimativas da correlação parcial entre a média dos gastos familiares e os indicadores de capital social concluíram que as famílias com maiores níveis de capital social têm significativamente altos níveis de renda. Ademais, questionou-se aos entrevistados sobre a "confiança". Particularmente, a confiança em estranhos e nos governos oficiais revelou não afetar diretamente a renda, mas possuía estreita relação com o capital social, justificando a idéia de que capital social é um determinante exógeno de renda.

\section{El Salvador: operacionalização do capital social - medida de confiança interpessoal}

Seligson \& Rennó (2000) procuram avaliar os modos de mensuração e apresentar indicadores alternativos de confiança interpessoal como uma das principais variáveis da teoria do capital social. Descrevem que um aspecto comum à maioria dos estudos, principalmente na América Latina, é a frágil operacionalização da variável confiança interpessoal. Geralmente, confiança é considerada variável unidimensional, dicotômica e mensurada no plano individual, quando é questionado se "a maior parte das pessoas é confiável ou não".

Mesmo aquém do ideal, existem na literatura diferenciações entre possíveis dimensões da confiança interpessoal. A categoria confiança personalizada se restringe à órbita da vida particular. A categoria confiança generalizada refere-se a formas que se expandem para além da esfera privada, da vida particular. Este tipo também pode ser medido através de autojulgamentos sobre a magnitude de confiança do entrevistado. Por se referir a autoavaliações (não se refere apenas à sensações generalizadas, pouco precisas) sobre outras pessoas, é mais direta e pode trazer resultados mais consistentes.

Seligson \& Rennó (2000) desenvolveram pesquisa em El Salvador afim de mensurar confiança interpessoal, através de duas dimensões. Primeiro, avaliaram a autoidentificação da confiança mútua e, segundo, registraram a imagem (generalizada) do quanto as outras pessoas são confiáveis. Posteriormente, utilizaram a análise fatorial para testar alguns itens $^{3}$ daquelas duas dimensões, concluindo que:

"... as distintas formas de mensurar confiança interpessoal não estão fortemente relacionadas, permitindo, portanto, testes separados de suas capacidades explicativas

\footnotetext{
${ }^{3}$ Os itens relacionados foram os seguintes: confiança nas promessas dos outros; confiança no que as pessoas dizem ao primeiro contato; confiança nas pessoas após bom tempo de conhecimento; confiança nas pessoas, em geral... )
} 
individuais ... tal distinção permite o teste de vários indicadores de confiança interpessoal. Os resultados contraditórios e conflitivos de estudos anteriores podem decorrer do fato de que essa bidimensionalidade do conceito de confiança interpessoal não é considerada por estudos prévios" (Seligson \& Rennó 2000, p.797 e 798)

Por certo, o trabalho de Seligson \& Rennó (2000) testifica que os conceitos presentes em ciências sociais clamam por definições, variáveis e indicadores mais precisos que ampliem a validade e a confiabilidade das análises, testes empíricos realizados e resultados encontrados, necessários para a consistência das discussões teóricas.

\section{Brasil: capital social, associações e desenvolvimento regional}

Abramovay (2000) procura explicar o dinamismo divergente das regiões. As análises foram fundamentadas no conceito de capital social como o conjunto de recursos que permite a utilização eficiente dos ativos econômicos pela comunidade. O autor cita o exemplo dos empreendimentos inovadores do Vale do Itajaí (Santa Catarina), em que a coordenação ente os atores sociais revela-se mais importante que as vantagens competitivas dadas por atributos naturais e de localização.

Para Abramovay (2000) os "meios inovadores", componentes territoriais da criação de novos recursos, é que determinam a dimensão territorial do desenvolvimento. Citando Maillot $(1996)^{4}$ ele conclui:

"a empresa não é um agente inovador isolado, ela parte do meio que a faz agir. O passado dos territórios, sua organização, seus comportamentos coletivos, o consenso que os estrutura são componentes maiores da inovação. Portanto, os componentes inovadores não são nacionais, mas dependem de variáveis definidas no plano local ou regional. O que caracteriza os "meios inovadores" não é a sua dotação em atributos naturais ou de localização, mas, antes de tudo, a densidade do seu tecido institucional, seu "capital de relações" (Abramovay 2000, p.386)

\footnotetext{
${ }^{4}$ MAILLOT, D. Comportements spatiaux et milieux innovateurs. In: Auray, Jean-Paul et al. Encyclopédie d'economies spatiale-concepts comportements, organisations. Paris: Economica, 1996.
} 
Nesse sentido, o Vale do Silício (costa oeste norte-americana), importante centro mundial de criação de novas tecnologias, é um exemplo do caráter territorial do desenvolvimento. Nessa comunidade de indústrias, as idéias são compartilhadas e o espírito de competição não condiz aquele da economia convencional de mercado. As trocas de informações, a preocupação comum com a formação dos trabalhadores e com a qualidade de vida são reflexos do ambiente de cooperação entre as empresas. Relação semelhante é observada no Brasil. Abramovay (2000) cita os casos do oeste de Santa Catarina e do sudoeste do Paraná, regiões com significativos registros de cooperativas. Envolvidas em organizações não-governamentais locais, essas áreas possuem mercados concorrentes que funcionam adequadamente.

\section{Belo Horizonte e Salvador: capital social, participação social, governança e desenvolvimento regional}

Capital social igualmente permite explicar diferenciais de desempenho governamental como elemento do desenvolvimento econômico. Por isso, estruturas específicas de governança e o progresso sócioeconômico de determinadas comunidades podem ser avaliados através da concepção de “... bons governos", entendidos como os que propiciam condições para a participação popular na produção de políticas publicas que bloqueiem ou neutralizem a vigência de práticas predatórias na relação entre agentes públicos e cidadãos" (Boschi 1999, p.655).

Segundo Boschi (1999), no período 1993-1996, as administrações diretas de Belo Horizonte e de Salvador se estruturaram em contextos diferenciados. Em Belo Horizonte, a economia dinâmica é dependente das atividades industriais; a população é mais homogênea, com menores taxas de crescimento e de pobreza. Em Salvador predomina o setor de serviços e comércio; observa-se maior índice de crescimento da população e maiores taxas de pobreza e desemprego.

O trabalho de Boschi (1999) também revela que, entre 1993 e 1996, as experiências de governança de Belo Horizonte e Salvador possuem pontos em comum. Tais administrações municipais opunham-se aos respectivos governos estaduais e ao governo federal. Em ambos os casos, os governos eram de orientação popular e objetivavam a participação da sociedade. Segundo Boschi (1999), é possível identificar as propostas de governança em três áreas de políticas, a saber: na esfera de políticas regulatórias (através dos planos diretores), nas propostas de utilização orçamentária (a partir dos orçamentos 
participativos) e nos planos de políticas regulatórias em áreas específicas (por meio dos conselhos setoriais).

Para Boschi (1999), as políticas regulatórias (mais abrangentes) configuradas nos arranjos macroinstituicionais traçam as formas na qual as experiências de governança desagregadas irão se desenvolver e delimitaram o nível de atuação dos atores estratégicos. Isso tem a ver com a formação de capital social ou, mais especificamente, com a existência de práticas e estruturas horizontais facilitadoras de relações simétricas. Nesse processo, a mobilização coletiva através de associações e outras estruturas representativas têm papel fundamental.

É no plano-diretor que residem as maiores diferenças entre as cidades de Salvador e Belo Horizonte. Diferenças presentes nos traços culturais, mas, principalmente, no conjunto de mobilizações coletivas e nos efetivos graus de descentralização administrativa. A pesquisa de Boschi (1999) descreve que, das duas áreas, Belo Horizonte é mais dotada de capital social. Nessa cidade, o contexto político é mais articulado nas diversas instâncias de governo (interna nas relações entre o Executivo municipal, Secretarias e a Câmara de Vereadores e externa nas relações do município com as esferas estadual e federal e demais atores da sociedade organizada). A prefeitura de Belo Horizonte teve por meta uma gestão participativa com adesão dos diversos setores da sociedade, num processo mais de renovação de procedimentos e estruturas do que de criação. O plano-diretor era o principal instrumento dessa gestão urbana, que englobava a análise, planejamento e regulamentação comunitária.

De acordo com Boschi (1999), o contexto político de Salvador é caracterizado por pequena descentralização administrativa e divergências entre a administração municipal e os governos estadual e federal. Esse quadro de relativo isolamento do governo municipal dificultou a mobilização e participação da sociedade no processo decisório da prefeitura de Salvador. A implantação de alguns instrumentos institucionais facilitadores da administração conjunta não trouxe grandes mudanças às práticas políticas tradicionais e aos impactos das ações locais. Por isso, efetivamente, o plano-diretor da capital baiana não representa o resultado de um processo compartilhado entre agentes públicos e privados na negociação da política urbana, mas apenas limitou-se ao papel de intermediário na resolução dos conflitos de uma estrutura desarticulada de planejamento.

Com relação ao orçamento participativo Boschi (1999) indica que também existem diferenças entre as experiências de Belo Horizonte e Salvador. Na capital mineira, o orçamento participativo foi resultado de mudanças institucionais ocorridas desde a década de 70 . $\mathrm{O}$ 
modelo de orçamento participativo combinava a participação de associações populares, outras entidades representativas e cidadãos avulsos. Desde o início, registrou-se número significativo de participantes, embora o objetivo principal não tenha sido com o volume de pessoas envolvidas, mas sim com a qualidade representativa deste número. Daí passou-se a incorporar critérios que garantissem a distribuição eqüitativa dos recursos públicos disponíveis. A estrutura do orçamento de Belo Horizonte fortaleceu as esferas de governo mais próximas dos atores e demandas sociais locais, contribuindo para a descentralização administrativa e melhor bem-estar, principalmente, para as populações de mais baixa renda.

A pesquisa de Boschi (1999) revela que na capital baiana a experiência de orçamento participativo é bem complexa. $\mathrm{Na}$ prática, houve dificuldade para alcançar a descentralização de decisões, ausência de uma estrutura representativa da comunidade, não absorção do modelo de orçamento por parte da Câmara Municipal, resistência do secretariado e problemas de articulação entre planejamento e orçamento. O discurso de articulação com a sociedade civil não era condizente com o reforço dos mecanismos tradicionais de planejamento, gestão do poder e orçamento. Assim, em Salvador, as decisões foram baseadas em negociações e decisões políticas centralizadas nas administrações superiores que facilitam a concretização dos interesses articulares.

No que diz respeito às experiências de políticas setoriais, segundo Boschi (1999), pode-se observar o desempenho dos conselhos como outra instância de representação popular, exemplificando o "Conselho Cultural" presente tanto em Belo Horizonte como em Salvador. No caso de Belo Horizonte o Conselho Deliberativo do Patrimônio Cultural do Município (CDPCM) contribuiu para ampliar a participação social no processo de gestão municipal para preservação do patrimônio e manutenção da qualidade de vida. O planejamento dos tombamentos e inventários dos bairros populares (listagem dos imóveis, descrição do processo histórico de ocupação etc.) com apoio das populações locais é um exemplo de envolvimento social e descentralização administrativa.

Nos resultados apresentados por Boschi (1999), quando o conselho do carnaval é analisado, a atuação da sociedade civil de Salvador se destaca. Como grande expressão de participação popular, cada vez mais o carnaval deixa de ser apenas diversão, tornando-se fonte permanente de renda, e o que era simples forma de expressão cultural, transformou-se num rentável negócio. Dessa forma, no início, a realização do evento era improvisada e posteriormente centralizada no poder público municipal. Porém, a festa alcançou magnitude tal que exigiu maior organização pública e privada, quando em 1989 criou-se o Conselho 
Municipal do Carnaval envolvendo os diversos segmentos relacionados ao evento. A gestão municipal do período 1993-1996 procurou ampliar a participação dos atores ao centralizar todas as ações dirigidas ao evento na Casa do Carnaval. O local abrigou o Núcleo Técnico, a Comissão Especial do Carnaval, a Coordenação do Carnaval e o Conselho Municipal do Carnaval. Esse conselho, ao articular os setores e como mediador dos conflitos entre os segmentos, garantiu as bases operacionais para realização da festa, que hoje possui uma estrutura eficiente, capaz de alavancar a economia municipal. Portanto, as experiências de Belo Horizonte e Salvador demonstram que os novos arranjos organizacionais que articulam os atores sociais, o público e o privado, viabilizam a cooperação e fortalecem o Estado, a sociedade civil e a economia num processo de causação circular.

\section{Bahia: capital social, associações e desenvolvimento regional}

Nascimento (2000) avaliou a experiência de organização sócio-econômica, concebida através da "Associação dos Pequenos Agricultores do Município de Valente" $\left(\right.$ APAEB-Valente) ${ }^{6}$. Semelhante a outros trabalhos, a pesquisa teve como referência a definição de capital social como conteúdo sinergético básico para a promoção do desenvolvimento. Nesse sentido,

"... o conceito de Capital Social significa certas características da organização social como laços, regras, sistemas e redes de sociabilidade, através das quais enfatizamos o papel da sociedade civil em gerar mudanças institucionais..." (Nascimento 2000, p.4)

"... Mais que representarem estoques acumulados ("capital imobilizado"), as relações sociais representam investimento partilhado ("capital mobilizado"), ou seja, uma forma ativa de capital social..." (Nascimento 2000, p.111)

Dessa forma, como resultado da capacidade de articulação da sociedade civil ${ }^{7}$, de uma região semi-árida, Nascimento (2000) comprova como a APAEB-Valente promoveu a sustentabilidade

\footnotetext{
${ }^{5}$ O município de Valente é situado a $270 \mathrm{~km}$ de Salvador, no Estado da Bahia.

6 Segundo Nascimento (2000) essa experiência foi recentemente avaliada como uma dentre as dez experiências socioeconômicas de caráter popular de maior êxito no Brasil pelo Programa Gestão Pública e Cidadania, coordenado pela Fundação Getúlio Vargas de São Paulo e Fundação Ford, cujos estudos contaram com o apoio do Banco Mundial e do Banco Nacional de Desenvolvimento Econômico e Social (BNDES)

7 A APAEB - Valente foi gestada pelo movimento social da região sisaleira e apoiada por Organizações Não-Governamentais (ONG's) nacionais e estrangeiras.
} 
dinâmica do território. Essa associação viabilizou a implantação de vários projetos econômicos ${ }^{8}$, mas, seu maior empreendimento foi a criação de uma Fábrica de Tapetes e Carpetes de Sisal. Em termos de geração de postos de trabalho, considerando todas as atividades da APAEBValente, em 1992 a associação gerou um total de 70 empregos diretos, em 1995, empregava 145 pessoas, mas em 1999 já registrava 790 ocupações. Nesse período, o aumento significativo de emprego deveu-se à criação da Fábrica, em 1996, quando nesse mesmo ano criaram 180 postos de trabalho e em 1999, somente a fábrica abrigou $70,9 \%$ do total de empregos gerados diretamente pela APAEB-Valente.

De acordo com Nascimento (2000), a verticalização produtiva também permitiu a melhoria dos preços médios pagos ao produtor pela tonelada do sisal. A fibra do sisal do tipo 3 passou de $R \$ 160,00 / t$ em 1995, para $R \$ 300,00 / t$ em 1998 e para $R \$ 322,00 / t$ em 1999. A fibra de tipo 2 variou de $R \$ 260,00 / t$ em 1996 para $R \$ 370,00 / t$ em 1999. A nova variedade criada pela associação, a fibra do tipo 1 , de melhor qualidade, ficou em $\mathrm{R} \$ 460,00 /$ t, valor $48 \%$ maior que o do mercado.

Através da APAEB-Valente, a evolução do setor sisaleiro é verificada sob vários aspectos. Para Nascimento (2000), além de melhorar a qualidade do produto, a valorização da produção foi conseqüência da possibilidade de acompanhamento orientado e de assistência técnica. No comércio internacional houve facilidade de penetração no mercado de fibras vegetais, e a produção municipal do sisal industrializado sobressaiu. A exportação nacional de carpetes e tapetes de sisal, saltou de $20 \%$ para $31 \%$. No Nordeste brasileiro a exportação de fibras de industrializadas de Valente situou-se entre o terceiro e quarto lugares, nos fins da década de 90 . O mais surpreendente é que esse desempenho deu-se num período de macroindicadores desfavoráveis, de abertura comercial açodada, sobrevalorização cambial, elevação dos juros e aumento dos índices de desemprego.

As mudanças no bem-estar da comunidade da APAEB-Valente vão além dos ganhos de renda. Uma pesquisa de campo, feita em 1998 pela própria associação, revelou mudanças significativas no padrão de vida familiar, afora outros indicadores sócioeconômicos: "A elevação do nível de renda e a melhoria no patrimônio familiar foram sintomas de acesso ao mercado de bens de consumo pessoal e de bens duráveis, bem como da melhoria geral da

${ }^{8}$ Segundo Nascimento (2000) a APAEB-Valente obteve êxito na viabilização de micros, pequenos e médios projetos econômicos, desde pequenas hortas e oficina artesanal de retalhos de tecido até uma micro-usina de beneficiamento do leite caprino. 
propriedade..." (Nascimento, 2000, p.102). Em suma, a experiência da APAEB-Valente permite concluir que:

“... através da organização, participação e articulação dos pequenos agricultores sertanejos, foi possível fomentar uma construção ativa de capital social e, consequentemente, promover uma revitalização das bases sócio-econômicas do processo de desenvolvimento numa tradicional área sisaleira do Estado da Bahia..." (Nascimento 2000, Resumo)

"As parcerias entre movimento social, entidades civis e governos pode fomentar a formação de ativo capital social em escala regional e em cada localidade, revitalizando as bases materiais (sociais e econômicas), ecológicas (convivência com o semi-árido) e imateriais (cultura, valores, tradições) do processo de desenvolvimento..." (Nascimento 2000, p.114)

Nascimento (2000) cita outros estudos empíricos ${ }^{9}$ que ratificam o papel essencial das cooperativas e associações, principais evidências da existência de capital social na América Latina como elemento dinamizador de desenvolvimento local. Em 1994, no Estado de Lara (Venezuela) haviam 85 cooperativas, mais de 3.500 redes de organizações governamentais, inúmeras associações de moradores e demais formas de organização social. As feiras de consumo popular da cidade de Barquisimeto (Venezuela), iniciadas em 1983, constituem outros exemplos. Formadas por grupos de produtores, associações de consumidores e pequenas empresas de autogestão regularam os preços e conseguiram baratear o custo dos produtos alimentícios para as populações carentes. Esse projeto é considerado "... um empreendimento eficiente no sentido schumpeteriano, útil em seu aspecto social, atraente como meio de vida e, no seu estilo solidário de gestão, tem se constituído numa concepção das mais promissoras e aceitas de Capital Social" (Nascimento 2000, p.18). Por fim, Nascimento (2000) faz referência ao Programa de Apoio aos Pequenos Produtores de Zacapa e Chiquimula $(\mathrm{PROZACHI})^{10}$, que garantiu aos camponeses o acesso ao desenvolvimento sustentável, por meio da democratização do crédito bancário, a assistência técnica e etc.

"O capital social, portanto, deixa de estar subordinado, exclusivamente, à trajetória histórico-cultural e passa a promover trajetórias diversas de mudança social, gerando

\footnotetext{
${ }^{9}$ Mais detalhes sobre os resultados das pesquisas realizadas na América Latina, aqui relacionadas, ver Nascimento (2000).

${ }^{10}$ Chiquimula fica situada na região oriental da Guatemala.
} 
alternativas e, por conseguinte, oportunidades de desenvolvimento..." (Nascimento 2000, p.22)

\section{Rio Grande do Sul: capital social, políticas públicas e desenvolvimento regional}

O trabalho de Verschoore Filho (2000) teve como objetivo central compreender o histórico e reduzido dinamismo econômico da região denominada Metade Sul do Rio Grande Sul, fundamentando-se no conceito de desenvolvimento endógeno e de capital social nas análises das políticas públicas local. Por certo, as modificações ocorridas nos processos produtivos e os divergentes níveis de crescimento econômico regional e nacional forçaram profundas transformações nas concepções sobre desenvolvimento, e é nesse ínterim que desponta a teoria do desenvolvimento endógeno. Essa teoria enfatizava que:

"A capacidade de a sociedade liderar e conduzir o seu próprio desenvolvimento regional, condicionando-o à mobilização dos fatores produtivos disponíveis em sua área e ao seu potencial interno, traduz a forma de desenvolvimento denominado endógeno. Podem-se identificar duas dimensões na endogenia do desenvolvimento regional. A primeira, econômica, na qual a sociedade empresarial local utiliza sua capacidade para organizar, da forma mais producente possível, os fatores produtivos da região. A segunda, sócio-cultural, onde os valores e as instituições locais servem de base para o desenvolvimento da região" (Verschoore Filho 2000, p.33)

A análise da evolução histórica da região Norte e Sul do Rio Grande do Sul esclarece a procedência dos divergentes desempenho econômico entre essas duas áreas. Segundo Verschoore Filho (2000), as causas do declínio da Metade Sul reside na própria estrutura social local; parte desse território foi formado por estâncias latifundiárias e charqueadas escravistas, caracterizadas por relações centralizadoras, autoritárias e pouco inovadoras. Também, a dificuldade em superar obstáculos e buscar soluções internas é outro fator limitante do progresso do Sul. No entanto, no Norte, parte do território foi formado via colonização e ocupação desconcentrada das terras. A presença do "espirito" comunitário, solidário e cooperativo tem facilitado a resolução dos problemas comuns e promovido o desenvolvimento da região. 
Para Verschoore Filho (2000), as estratégias políticas de desenvolvimento regional devem atentar-se ao estoque de capital social, fomentando o desenvolvimento regional cívico ${ }^{11}$. O Estado deve atuar promovendo o fortalecimento da participação, da organização e de práticas de colaboração social na busca conjunta de soluções para problemas comuns e construção de oportunidades econômicas. Por isso, a necessidade de estudar as políticas locais de desenvolvimento, como um produto endógeno, para a compreensão do desenvolvimento recente da região Metade Sul do Rio Grande do Sul.

De acordo com Verschoore Filho (2000), a política gaúcha a partir do final da década de 70 caracteriza-se pela dispersão e descontinuidade de objetivos, estratégias e instrumentos adotados, gerando obviamente resultados limitados e pouco duradouros. Analisando o período 1979-83, conclui que o governo de José Augusto Amaral de Souza tinha um discurso em torno da necessidade de desconcentração industrial. Na prática, as políticas implementadas não permitiram reverter o quadro de concentração produtiva em torno da região metropolitana.

Verschoore Filho (2000) considera que, entre 1983 e 1987, o governo de Jair de Oliveira Soares através das políticas desenvolvimentistas procurou redirecionar os investimentos públicos e privados buscando expandir a atividade produtiva das regiões mais carentes. No entanto, as diretrizes foram insuficientes e superficiais, relacionadas à melhoria da infra-estrutura básica e do sistema de transportes, por exemplo, alcançando apenas as conseqüências do processo e consideradas incapazes para promoção do desenvolvimento.

O trabalho de Verschoore Filho (2000) assinala que, no período 1987 e 1991, o governo de Pedro Jorge Simon intentou incorporar a sociedade civil e estratégias associativas no planejamento político. Mesmo representando um modelo inovador de política pública para o desenvolvimento, os resultados comprovam que, na prática, as propostas e planos de ação apresentados não foram totalmente concretizados.

Para Verschoore Filho (2000), o mandato de Alceu de Deus Collares, entre 1991 e 1994, trouxe grande contribuição a todo o estado, principalmente para as regiões menos dinâmicas. Por meio da criação dos Conselhos Regionais de Desenvolvimento, ".. a ação do Estado esteve voltada a expandir a capacidade social das regiões em discutir, elaborar e,

11 Para maiores detalhes sobre a concepção de desenvolvimento regional cívico ver Verschoore (2000), que cita as contribuições de vários autores. 
inclusive, promover o seu próprio desenvolvimento, bem como enfrentar os desafios que a ela sejam impostos" (Verschoore Filho 2000, p.155)

Segundo Verschoore Filho (2000), os planos de governo de Antônio Britto Filho, entre 1995 e 1998, embora sublinhassem a geração e acúmulo de capital social, efetivamente realizaram pouca coisa. Nesse período, procurou-se revisar a iniciativa dos Conselhos Regionais de Desenvolvimento, reduzindo sua capacidade como fomentador do dinamismo social. Em 1998, foi implantada a Consulta Popular, mas, em síntese, nesse governo "os instrumentos adotados compreendiam, de forma insuficiente, as relações sociais e os elementos cívicos fundamentais ao processo" (Verschoore Filho 2000, p.156).

Portanto, em geral, Verschoore Filho (2000) considera as políticas regionais no Rio Grande do Sul insuficientes para reduzir as desigualdades entre as regiões Norte e Sul do Estado. Por isso, o autor sugere, como alternativa, ações públicas efetivamente direcionadas à ampliação dos estoques de capital social e à promoção do desenvolvimento endógeno, principalmente no Metade Sul do Rio Grande do Sul, com o objetivo de reverter o quadro de disparidades regionais.

Outros trabalhos analisam a relação capital social, desempenho governamental e desenvolvimento econômico. Segundo Monastério (s.d.), Putnam afirma que processos de descentralização e os melhores indicadores de desempenho governamental, em meados da década de 1970, na Itália, ocorreram nas regiões intensas em capital social. Nesse sentido, Verschoore Filho (2000) cita a pesquisa realizada por Nicholls, que procurou explicar as diferenças de crescimento entre o Sul e o Norte dos Estados Unidos. Aqui, os elementos de tradição: “(...) a dominância dos valores agrários, a rigidez da estrutura social, a estrutura política antidemocrática, a pouca responsabilidade social, a mentalidade e o comportamento conformistas" (Verschoore Filho 2000, p.39) foram considerados os fatores responsáveis pelo menor dinamismo da região Sul norte-americana. Resumindo aquela relação, Monastério (s.d.) cita Putnam \& Helliwell (1995) ${ }^{12}$, que justificam e corroboram evidências econométricas da hipótese de conexão causal do estoque de capital social para o bom governo e, então, para o crescimento econômico.

${ }^{12}$ PUTMAN, R.; HELLIWELL, J. Economic growth and social capital in Italy. Eastern Economic Journal, v.21, n.3, p.295-307, 1995. 
ANEXO B - ALGUNS ESTUDOS SOBRE OS EFEITOS NA ECONOMIA DOS ESTOQUES DE CAPITAL NATURAL

\section{Canadá}

Fenech et al. (1999) realizou uma pesquisa para avaliar o "papel" dos ecossistemas e a bio-diversidade na economia do Canadá. Para tanto, examinou duas questões fundamentais: a primeira, quanto ao valor ou benefícios diretos das atividades relacionadas à vida selvagem; e a segunda, sobre os benefícios indiretos gerados pelo uso sustentável da pesca e outros recursos. Os resultados indicam o nível de gastos incorridos com as atividades relacionadas ao meio-ambiente no Canadá. Os residentes locais gastaram $\$ 5,6$ bi em atividades relacionadas a vida selvagem durante 1991. Desse dispêndio total, aproximadamente $\$ 1,2$ bi (21\%) foi gasto em caça e outros $\$ 2,4$ bi $(43,6 \%)$ o foram em excursões ou passeios. O restante, cerca de $\$ 2$ bi $(35,1 \%)$, foi gasto em outras atividades relacionadas à vida selvagem (contribuições para organizações ambientais, preservação de áreas naturais etc.)

As estimativas de Fenech et al. (1999) constatam o importante impacto da vida selvagem sobre a economia canadense. Esses impactos são expressados através de medidas que revelam a contribuição do meio ambiente na formação do Produto Nacional Bruto (PNB), renda pessoal, número de empregos e receita governamental, por exemplo. No caso do Canadá, os gastos relacionados à vida selvagem contribuíram em $\$ 7,0$ bi para a formação do PNB. Cerca de 126 mil postos de trabalho foram mantidos e $\$ 3,8$ bi em renda pessoal, contabilizados. As taxas sobre bens e serviços variados e sobre rendas pessoais e de negócios geraram $\$ 3,1$ bi de receita recebida por governos federais, provinciais e locais.

\section{Austrália, Suécia, América Latina e Caribe}

Perry (2001) procura elucidar as vantagens que os países detentores de recursos naturais podem obter. Argumenta que em grande parte dos países desenvolvidos ou em desenvolvimento as economias dependem, direta e indiretamente, dos respectivos recursos naturais. Conforme Perry (2001), na Austrália as indústrias de derivados de lã e as mineradoras transformaram a economia do país. Foram as descobertas de novas jazidas e a geração e exportação de conhecimentos na área, principalmente no que diz respeito ao processamento sustentável, que garantiram o desenvolvimento nacional. Na Suécia, as indústrias Volvo, Saab e Nokia surgiram, em parte, encadeadas à indústria florestal. Por certo, as estruturas organizacionais, as redes de conhecimento e políticas de capital humano desenvolvidas em prol 
do processamento de recursos naturais, mas transferidas às indústrias de alta tecnologia, são elementos essenciais da progressão econômica dessas nações. No Brasil, a descoberta de depósitos de minério de ferro, bauxita, estanho e cobre através de novas técnicas de exploração e extração, confirmam esta observação. "Em suma o registro histórico é claro: quando bem administrados e situados na estrutura institucional adequada, os recursos naturais podem ser vitais para o desenvolvimento" (Perry 2001, p.4)

"Devemos reiterar que uma combinação de dotes de recursos naturais e uma agressiva busca e adoção de novas tecnologias apropriadas a essa riqueza é uma receita de crescimento comprovada. Além disso, fortes evidências indicam que o seu desenvolvimento não abre mão do desenvolvimento da manufatura e de outras atividades da economia do "conhecimento". Em suma os países que "aproveitaram suas vantagens" tem tido bom desempenho" (Perry 2001, p.10)

De acordo com Perry (2001), do mesmo modo que os recursos minerais e a aptidão agrícola, os recursos turísticos devem ser administrados. A qualificação da infraestrutura local e da mão-de-obra, a diferenciação de produtos ofertados (se ecoturismo, se turismo ecológico, ou turismo rural...), a preservação do patrimônio histórico-cultural e natural etc. é que irá garantir o dinamismo do setor e a sustentação dos padrões de vida em áreas turísticas como da América Latina e Caribe, por exemplo.

"... O desenvolvimento baseado em recursos naturais deve cuidar muito especialmente para não desperdiçar a própria riqueza natural ou de condescender os efeitos ambientais adversos. A proteção e a eficiente gestão são elementos essenciais para manutenção ou melhoramento de reservas de recursos naturais renováveis em atividades tais como a silvicultura, a pesca, a agricultura e o turismo, e para evitar a degradação ambiental decorrente da mineração. Instituições sólidas e conhecimento são, mais uma vez, "a chave" para harmonizar a eficiência econômica com metas ambientais". (Perry 2001, p.12)

\section{México}

Abaza (1992) apresenta os resultados da aplicação do "Sistema de Contabilidade Econômica e Ambiental Integrada (SICEA)" na Papua Nova Guinea (PNG) e México. O principal objetivo do pesquisador foi testar a metodologia do SICEA na tentativa de fornecer uma avaliação precisa dos indicadores econômicos modificados, aperfeiçoando as informações sobre a conexão economia-meio ambiente. Para tanto, estima dois indicadores: o "Produto 
Doméstico Ambiental 1 (PDA 1)", que mensura a depleção dos recursos naturais; e o "Produto Doméstico Ambiental 2 (PDA 2)", que, além da depleção, engloba a degradação ambiental, calculado para deduzir o custo de degradação na forma de poluição do ar, erosão do solo e devastação. Além do método do Preço Líquido (PL), foi utilizado o método do "Custo de Uso". Este último, proposto por El Serafy, do Banco Mundial, surgiu da noção de investir porção da renda recebida pelo uso e conseqüente depleção do recurso natural, afim de generalizar um fluxo permanente de renda.

Abaza (1992) descreve as especificidades dos trabalhos realizados no México e PNG e resume os resultados, realçando as diferenças em termos de definições, hipóteses, métodos, principalmente em relação às duas medidas agregadas (PDA1 e PDA2). No estudo do México, a acumulação líquida de capital resulta do crescimento ou decréscimo do estoque de recursos naturais. Em contraste, o método empregado na PNG não inclui o crescimento dos recursos naturais, da mesma forma que o sistema convencional de contabilidade. Dessa forma, como os dois países utilizaram métodos diferenciados, torna-se inútil um análise comparativa dos resultados. Por esses motivos, basta atentar para os resultados apresentados pelo método aplicado para o México, julgado eficiente como indicador do nível de sustentabilidade. Enfim, no México as estimativas dos estoques de capital natural, calculado e comparado com os agregados modificados, revelam que o país experimenta considerável crescimento econômico sustentável; PDA1 e PDA2, alcançaram, respectivamente cerca de $94 \%$ e $87 \%$ do valor do Produto Doméstico Líquido (PDL).

O próprio Abaza (1992), no entanto, afirma que o SICEA, para se firmar como metodologia útil nas estimativas dos indicadores de sustentabilidade e bem-estar de uma ação, carece de maior aplicabilidade, mais resultados práticos e maior avaliação dos dados que garantam aquela condição.

\section{Chile}

A pesquisa realizada por Figueroa \& Calfucura (2002) parte do princípio de que alcançar o máximo de bem-estar social requer a exploração ótima da base dos recursos naturais, especialmente nos países em desenvolvimento, cujas economias dependem fortemente de tais recursos. Como a contabilidade nacional, nas estimativas dos custos, não leva em conta as perdas ambientais, tal sistema produz indicadores econômicos tradicionais que sobrestimam o verdadeiro valor da riqueza dos países. Por isso, esses autores desenvolvem um modelo simples de correção do Produto Interno Bruto (PIB) para obter uma medida da renda econômica sustentável. Esse procedimento está fundamentado nos diversos 
trabalhos que tem procurado avaliar a exploração dos recursos naturais no processo desenvolvimento sustentável.

Figueroa \& Calfucura (2002) corrigem o PIB e o Produto Nacional Líquido (PNL) pelos valores da depreciação das atividades extrativas (através do método do Preço Líquido $\mathrm{PL}$ ) e da degradação ambiental (produto da contaminação atmosférica que considera o material individualmente respirável - MP10), medidas correspondentes ao "sistema de contas verdes ou satélites". A primeira medida do Produto Nacional Líquido Corrigido (PNL-C) denominada PNL$\mathrm{C} 1$ corresponde à correção que subtrai do $\mathrm{PNL}$ a depreciação dos recursos naturais. A segunda medida corrigida, o Produto Nacional Líquido Corrigido (PNL-C2) corrige o PNL pela depreciação dos recursos naturais e pela depreciação devida à degradação ambiental. Também, foi estimado outro indicador apropriado de sustentabilidade, a "Poupança Nacional Natural (PNN)", que considera o PNB menos o consumo privado (C), menos o gasto de consumo do governo $(G)$, menos a depreciação de capital físico, menos a perda líquida de capital natural (recursos naturais e degradação ambiental) e se agregam os gastos em educação. As informações disponíveis possibilitaram realizar a pesquisa nos distintos setores da economia, para o período de 1985-1997, considerando os recursos minerais cobre, petróleo, ouro, recursos pesqueiros e a contaminação do ar. As cifras macroeconômicas tradicionais utilizadas neste trabalho provem das estatísticas oficiais do Banco Central do Chile, especificamente do Anuário das Contas Nacionais. ${ }^{13}$

Segundo os resultados encontrados por Figueroa \& Calfucura (2002), a economia chilena, das últimas décadas do século $X X$ obteve desempenho superior ao do resto da América Latina e Caribe. A taxa média de crescimento anual do Chile, ao redor de $7 \%$, foi maior que a de qualquer outro país desta área e mais que o dobro da taxa de crescimento experimentado pela região como um todo. Este desempenho foi baseado fundamentalmente nas explorações e exportações dos recursos naturais, quando se observou que cerca de $90 \%$ do valor total exportado pelo país corresponde a recursos naturais processados e não processados.

Para Figueroa \& Calfucura (2002), a estrutura produtiva chilena promove redução dos ativos naturais, tornando-se necessário identificar o impacto das práticas econômicas no bem-estar da população. No agregado, os resultados mostram que cerca de $3 \%$ da renda econômica do Chile corresponde à depreciação do meio-ambiente. No que diz respeito aos

\footnotetext{
${ }^{13}$ As discussões e fórmulas utilizadas estão minuciosamente descritas em Figueroa \& Calfucura (2002).
} 
setores da economia, os níveis de degradação e depreciação promovidos pelas atividades são diferenciados. A maior perda de capital natural de recursos não-renováveis está associada ao cobre $^{14}$, explicável pela importante participação desse metal na economia nacional. O setor petrolífero registra reduções de depreciação por causa do esgotamento das reservas no extremo sul do país e conseqüente redução dos níveis de extração dos últimos anos. Em volume, o subsetor carbonato de cálcio apresenta os menores valores de depreciação devido à sua pequena participação relativa no produto mineral nacional.

Sobre a degradação ambiental, várias informações foram obtidas por Figueroa \& Calfucura (2002). Estimou-se uma medida do custo marginal de abatimento da contaminação por habitante, cujo valor alcançou $\$ 145 / \mathrm{ug} / \mathrm{m} 3 / \mathrm{habitante}^{15}$. Este custo marginal foi aplicado a todas as áreas urbanas consideradas nas análises. A respeito da contaminação do ar, seu valor anual cresceu monotonicamente até o ano de 1993, para então "diminuir nãomonotonicamente a partir desse $a^{16}{ }^{16}$..." (p.16). A depreciação ambiental total (dos recursos naturais mais serviços ambientais) como porcentagem do produto alcançou quase $3,5 \%$, no início do período $1985-1997$ e $2,7 \%$ no final deste espaço de tempo. Isto demonstra que os custos ambientais do crescimento do país têm tendido a decrescer, resultado da redução da contaminação aérea, especialmente, resultante das políticas ambientais aplicadas.

Segundo o PNL-C1, calculado por Figueroa \& Calfucura (2002), o PIB sobrestima em $25 \%$ o volume real da riqueza sustentável. Isto quer dizer que, quando se utiliza a medida tradicional do PIB com o propósito de indicar a renda econômica gerada pela economia em um ano e seu nível de bem-estar associado, está-se usando uma medida que sobrestima em uma quarta parte a verdadeira renda econômica. Também, é possível observar que a medida de PNL sobrestima em aproximadamente $2 \%$ essa renda. De acordo com o PNL-C2, o PIB sobrestima em $27,2 \%$ o produto nacional; e o PNL sobrestima a renda do Chile em 3,6\%. Estas estimativas indicam que a sobrestimação da renda econômica não é desprezível e deve ser observada ao considerar a sustentabilidade do crescimento da economia.

\footnotetext{
${ }^{14}$ A depreciação anual média do subsetor cobre é 3,1 vezes maior do o subsetor ouro, 7,3 vezes maior que a do subsetor petróleo, e quase 38 vezes maior que do subsetor carbonato de cálcio. Em milhões \$ de 1986 estes subsetores registraram, respetivamente, os seguintes valores de depreciação: $50.584,16.214$, 6.902 , e 1.334 .

${ }^{15}$ Cifra expressa em pesos de 1886.

16 A degradação ambiental, medida em milhões \$ (de 1986), alcançou 58.389 em 1985, aumentando nos anos subsequentes até 1993 (81.328). Após este período, experimentou reduções, chegando em 1997 com 74.414 .
} 
As medidas da Poupança Nacional Natural (PNN), estimados por Figueroa \& Calfucura (2002), apresentaram uma tendência crescente desde o ano de 1985 até o ano de 1993, quando alcançaram seu pique, com uma taxa de 9,8\% do PIB. Posteriormente se observa uma tendência decrescente explicada pelas menores taxas de investimento em capital físico e a maior depreciação do capital físico e natural. Em suma, exceto o ano de 1995, a economia chilena mostra uma taxa de $\mathrm{PNN}>0$ para todos os anos da série. Portanto, todos as estimativas apresentadas ratificam que a economia chilena experimentou um crescimento econômico sustentável durante o período 1985-1997.

\section{Brasil}

Torras (2000) procurou avaliar o nível de sustentabilidade brasileira entre 1965 e 1993. Especificamente, buscou compreender em que medida o uso dos recursos naturais afetou o nível de bem-estar social. Para tanto, utilizou um método de "contabilidade verde", que corrige as estimativas do PIB pelo valor dos recursos naturais exauridos.

Para o Brasil, a "renda sustentável" ou o "PIB verde" foram estimados por meio da "contabilidade verde". Segundo Torras (2000), esses cálculos já foram obtidos por um número significativo de pesquisas, como as realizadas pela "World Resources Institute" (WRI) sobre a Indonésia e Costa Rica. Então, seguindo os métodos aplicados nesses trabalhos, ele calculou o crescimento da renda sustentável "per capta" e o comparou com o crescimento do PIB do período 1965-1993. Aprofundando a discussão da questão sustentabilidade, a formação bruta de capital, ou investimento, foi comparada com o investimento líquido, estimado do valor da depleção dos recursos. Também, foi mensurado o "investimento doméstico ajustado à depleção (IDAD)" e o índice "Pearce e Atkinson (P\&A)". A metodologia empregada para estimar o valor dos diferentes recursos são descritas a seguir:

1) primeiramente, a contabilidade dos recursos naturais estimou o Valor Presente Líquido (VPL) dos recursos minerais e madeiras, que é a soma dos lucros futuros derivados desses recursos. A abordagem utilizada foi a do Preço Líquido $(P L)^{17}$, considerada mais adequada e menos trabalhosa. Assim, o "valor do estoque" e a "depreciação" daqueles recursos foram estimados ${ }^{18}$;

\footnotetext{
17 A abordagem do Preço Líquido (PL) trata a depleção dos recursos naturais semelhante a forma tradicional de depreciação do capital.

18 Todas as fórmulas e demais considerações práticas referentes às estimativas do "valor do estoque" e "depreciação" dos recursos minerais e madeiras, estão apresentadas em Torras (2000).
} 
2) em seguida, a contabilidade do solo partiu das estimativas da erosão desse recurso, através do método do "custo de reposição". Essa abordagem enfatiza os nutrientes (por exemplo, nitrogênio, fósforo, potássio) que contribuem para o crescimento das safras cuja produção foi reduzida como resultado da erosão, ou seja, o valor associado à erosão do solo ${ }^{19}$ é deduzido do gasto com aquisição de fertilizantes químicos requeridos para suprir o solo em nutrientes.

Os resultados ${ }^{20}$ encontrados por Torras (2000) revelaram a frágil sustentabilidade da economia brasileira. Primeiramente, comparando a contabilidade tradicional com a dos recursos naturais, os dados indicam que existem diferenças significativas entre os indicadores estimados. Entre 1965 e 1993, observa-se que o PIB brasileiro aumentou cerca de quatro vezes, enquanto a renda sustentável cresceu pouco mais de duas vezes. A depleção de recursos - principalmente de extração mineral e devastação das florestas, que acelerou na década de 80, explica a diferença. O quadro "per capta" ratifica essas conclusões; enquanto o PIB "per capta" mais que dobrou de 1965 para 1993, e a renda sustentável "per capta" aumentou somente um terço. Ao comparar o investimento bruto ou a formação bruta de capital com os valores da depleção dos recursos naturais, constatou-se que o Brasil está reduzindo seu estoque de capital, usando os recursos naturais para financiar o consumo, prática considerada insustentável diante da finitude dos bens e serviços naturais. O "investimento doméstico ajustado à depleção (IDAD)" e o índice P\&A foi negativo (mas crescente em termos absolutos) ao longo dos anos, ambos ratificando que a economia brasileira tem se desviado da medida de sustentabilidade em cada ano, principalmente no período recente.

Por fim, diante dos resultados encontrados, Torras (2000) faz algumas sugestões. Maior investimento para preservação do estoque de capital natural, por meio de programas que promovam o reflorestamento e incentivem a diversificação econômica e práticas agrícolas não degradantes ao solo, por exemplo, são algumas diretrizes políticas que auxiliariam o Brasil a se inserir no curso do desenvolvimento econômico sustentável.

Segundo Motta (1997), a questão sustentabilidade tem sido cada vez mais fator limitante do desenvolvimento dos países. Nesse sentido, a atual tendência mundial de restrições comerciais de cunho ambiental pode alterar as vantagens comparativas de alguns países, criando barreiras à entrada de alguns produtos no mercado internacional. Assim,

\footnotetext{
19 Todas as fórmulas e demais considerações práticas referentes às estimativas do valor da "erosão do solo" e "quantidade de perda dos nutrientes", estão apresentadas em Torras (2000).

20 Todos os resultados e indicadores estimados através de fórmulas e definições estão descritos minuciosamente (ano a ano) em Torras (2000).
} 
qualquer hipótese de sustentabilidade do crescimento econômico precisa considerar os esforços de investimento, os quais devem ser equivalentes ao consumo agregado de capital da economia, seja este natural ou material.

No caso brasileiro, por exemplo, o estudo realizado por Motta (1997) revela que, além do consumo de capital natural nacional crescente, não estão sendo realizados os investimentos necessários para a recomposição do nível de estoque dos recursos ambientais. Por isso, o autor sugere que as diretrizes políticas brasileiras precisam atentar para a condicionante ambiental como uma das variáveis determinantes da forma da inserção internacional da economia no processo de desenvolvimento. Também, ressalta que, "no longo prazo, parece inevitável um processo de ajuste no padrão ambiental da economia nacional, de forma a assegurar sua eficiência competitiva..." (Motta 1997, p.11). Só assim, pode-se evitar sérias restrições ao progresso e bem-estar social do Brasil.

Portanto, o avanço nas pesquisas mundiais sobre o capital natural tem promovido maior conhecimento, conscientização e capacitação no tratamento da questão meio ambiente, economia e sobrevivência humana. 


\section{ANEXO C - QUESTIONÁRIO AO TURISTA}

\section{ANÁLISE DA ATIVIDADE TURÍSTICA \\ DO MUNICÍPIO DE ILHÉUS}

Obs: Todas as informações registradas abaixo serão mantidas em absoluto sigilo e constituem uma das etapas de pesquisa acadêmica desta instituição.

\section{PARTE 1 - AVALIAÇÃO DA ATIVIDADE TURÍSTICA DO MUNICÍPIO DE ILHÉUS}

1.1) DÊ UMA NOTA, NA ESCALA DE ZERO (0) À DEZ (10), PARA AVALIAR OS EQUIPAMENTOS E SERVIÇOS TURÍSTICOS:

1.1.1)Os meios de hospedagem (estrutura física dos hotéis/pousadas/camping/casas/apartamentos alugados ...)

1.1.2) Os equipamentos de lazer/entretenimento (bares/boates/teatros/cinemas/playcenter...)

1.1.3) O comércio em geral

1.1.4) O comércio de artesanatos

1.1.5) Os serviços de higiene e limpeza dos hotéis, pousadas, restaurantes, bares...

1.1.6) Os serviços de alimentação dos hotéis, pousadas, restaurantes, bares...

1.1.7) Os passeios oferecidos

1.1.8) Os serviços de recepção, informação e guias de turismo

1.1.9) O patrimônio histórico/cultural

1.1.10) As manifestações populares

1.1.11) Entretenimentos/diversões diurnas

1.1.12) Entretenimentos/diversões noturnas

1.2) DÊ UMA NOTA, NA ESCALA DE ZERO (0) À DEZ (10), PARA AVALIAR A INFRA-ESTRUTURA DO MUNICÍPIO DE ILHÉUS:

1.2.1) O abastecimento de água

1.2.2) A pavimentação das ruas

1.2.3) A sinalização urbana (do DETRAN)

1.2.4) A sinalização turística 
1.2.5) A limpeza pública

1.2.6) A segurança pública

1.2.7) Os meios de comunicação (telefone, correio e etc.)

1.2.8) Os meios de transportes inter-municipais, inter-regionais, inter-estaduais (disponibilidade e qualidade dos vôos, dos ônibus...)

1.2.9) Os meios de transportes inter-urbano (disponibilidade e qualidade dos ônibus, taxis, aluguéis de carros, barcas, balsas e etc.)

1.3) DÊ UMA NOTA, NA ESCALA DE ZERO (0) À DEZ (10), PARA AVALIAR AS FACILIDADES DE PAGAMENTO/FINANCIAMENTO DOS CUSTOS DA VIAGEM:

1.3.1) O acesso aos serviços bancários (disponibilidade/qualidade dos serviços dos caixas eletrônicos e etc.)

1.3.2) A aceitação de pagamentos via cartão de crédito e cheques diversos

1.3.3) O valor das diárias dos meios de hospedagem

1.3.4) Os preços dos serviços de alimentação

1.3.5) Os preços dos serviços de lazer e entretenimento

1.4) DÊ UMA NOTA, NA ESCALA DE ZERO (0) À DEZ (10), PARA AVALIAR OS RECURSOS NATURAIS PRESENTES NO MINICÍPIO DE ILHÉUS:

1.4.1) Amenidades ambientais (beleza das praias, lagoas, mangues ...)

1.4.2) Coleta de lixo das praias, rios, lagoas, mangues...

1.4.3) Limpeza dos banheiros existentes nas praias, rios, lagoas, mangues

1.4.4) Distribuição das redes de esgotos próximos às praias, rios, lagoas, mangues

1.4.5) Aspecto visual das barracas, cadeiras... existentes nas praias/rios/lagoas/mangues

1.5) A Lagoa Encantada, as praias, os rios, os mangues de llhéus podem ser facilmente depredados se houver excesso de visitas ou se não forem bem cuidados. Para ajudar na preservação e manutenção destes recursos naturais, o (a) senhor (a) estaria disposto (a) a pagar uma taxa de R\$ sem pagar nada? pelo uso dos mesmos, lembrando que poderia visitar lugares como Prado, Porto Seguro,

\subsection{1) $\operatorname{Sim}($ ) 1.5.2) Não ( )}

1.6) DÊ UMA NOTA, NA ESCALA DE ZERO (0) À DEZ (10), PARA AVALIAR A CAPACIDADE (NÍVEL DE QUALIFICAÇÃO/PREPARO/CONHECIMENTO):

1.6.1) dos guias de turismo, gerentes, camareiras, garçons, recepcionistas e outros profissionais diretamente envolvidos na atividade turística 
1.6.2) dos vendedores, lojistas, ambulantes, camelôs e demais pessoas direta e indiretamente envolvidos na atividade turística

1.7) SOBRE A POPULAÇÃO ILHEENSE, AVALIE, NUMA ESCALA DE ZERO (0) À DEZ (10):

1.7.1) A receptividade da população do município de ilhéus

1.7.2) A confiança na população (em relação aos serviços de taxi, informações obtidas sobre a qualidade e valor dos produtos/serviços ofertados e etc.)

1.8) A influência desta viagem deveu-se a:

1.8.1) Comentário de parentes/amigos ( )

1.8.3) Propaganda/Publicidade ( )

1.8.5) Livros/TV/Filmes ( )

1.8.7) Outros ( )

1.8.2) Agência de Viagens ( )

1.8.4) Internet ( )

1.8.6) Já conhecia o local visitado ( )

1.9) DIANTE DE TODA A AVALIAÇÃO REALIZADA ANTERIORMENTE, ATRIBUA UMA NOTA, ENTRE (0) ZERO E (10) DEZ, PARA O TURISMO DO MUNICÍPIO DE ILHÉUS

1.10) MESMO DIANTE DE TODA A AVALIAÇÃO REALIZADA ANTERIORMENTE, O(A) SENHOR(A) VOLTARÁ A VISITAR A CIDADE DE ILHÉUS?

$\operatorname{SIM}($ ) NÃO ( )

1.11) MESMO DIANTE DE TODA A AVALIAÇÃO REALIZADA ANTERIORMENTE, O (A) SENHOR (A) RECOMENDA, A OUTRAS PESSOAS, UMA VISITA À CIDADE DE ILHÉUS ?
1.11.1) $\operatorname{SIM}($ )
1.11.2) NÃO ( )

\section{PARTE 2 - IDENTIFICAÇÃO DO TURISTA}

2.1) Sexo: $\quad M() \quad F($ )

2.2) Fazem quantos dias que visita a cidade de llhéus?

2.3) Qual a sua cidade de origem ?

2.4) Qual o seu estado de origem ?

2.5) Qual o seu país de origem

2.6) O que motivou sua viagem a esta cidade?

2.6.1) Passeio/Lazer ( )

2.6.3) Visita a parentes e amigos ( )

2.6.5) Congresso/Convenção ( )

2.6.7) Outros

2.6.2) Religião ( )

2.6.4) Negócios ( )

2.6.6) Saúde ( )

2.7) Quantas pessoas estão viajando com o(a) senhor (a)?

2.7.1) Adultos

2.7.3) Homens

2.8) Sua idade se insere em que faixa etária?

2.8.1) Abaixo de 18 anos ( )

2.8.3) De 26 a 35 anos ( )

2.8.5) De 51 a 65 anos ( )
2.7.2) Crianças

2.7.4) Mulheres

2.8.2) De 18 a 25 anos ( )

2.8.4) De 36 a 50 anos ( )

2.8.6) Acima de 65 anos ( ) 
2.9) Qual o seu estado civil?

2.9.1) Solteiro(a) ( )

2.9.3) Viuvo(a) ( )
2.9.4) Casado (a) ( )

2.9.2) Desquitado(a)/Divorciado(a) ( )

2.9.5) Outros

2.10.2) $1^{0}$ Grau Completo ( )

2.10.4) $2^{0}$ Grau Completo ( )

2.10.6) Superior ( )

2.10) Qual o seu grau de instrução?

2.10.1) $1^{0}$ Grau Incompleto ( )

2.10.3) $2^{0}$ Grau Incompleto ( )

2.10.5) Técnico ( )

2.10.7) Outros

2.11) Qual a sua profissão? (Ocupação Principal)

2.12) Sua renda mensal Individual, insere-se em que faixa? (valores expressos em $R \$$ )

2.12.1) até 604,00 ( )

2.12.3) de 756,00 a $1.359,00$ ( )

2.12.5) de $1.511,00$ a 2.114,00 ( )

2.12.7) de $2.266,00$ a $2.869,00$ ( )

2.12 .9 ) de $3.021,00$ a $3.624,00$ ( )

2.12.11) de 3.776 a $4.379,00$ ( )

2.12.13) $4.531,005.134,00$ ( )
2.12.2) de 605,00 a 755,00

2.12 .4 ) de $1.360,00$ a $1.510,00$ ( )

2.12 .6 ) de $2.115,00$ a $2.265,00$ ( )

2.12 .8 ) de $2.870,00$ a $3.020,00$ ( )

2.12 .10 ) de $3.635,00$ a $3.775,00$ ( )

2.12.12) de $4.380,00$ a 4530,00 ( )

2.12.14) a partir de $5.135,00$ ( )

2.13) Qual o meio de transporte utilizado para o(a) senhor(a) chegar a esta cidade? 2.13.1) Automóvel ( )

2.13.3) Avião ( ) 2.13.2) Ônibus ( )

2.13.4) Outros

(INFORMAÇÕES ADICIONAIS)

Data

Hora

Entrevistador

Local

$\mathrm{N}^{0}$ de leitos $\mathrm{N}^{0}$ de Unidades Habitacionais 
ANEXO D - Perfil/características (estado civil, faixa etária, nível de instrução, nível de renda, sexo e estado de origem) do turista de ilhéus, em percentagem.

\begin{tabular}{|c|c|}
\hline \multirow{2}{*}{\multicolumn{2}{|c|}{$\begin{array}{l}\text { Perfil/Características } \\
\text { Sexo }\end{array}$}} \\
\hline & \\
\hline Masculino & 54,4 \\
\hline Feminino & 45,6 \\
\hline \multicolumn{2}{|c|}{ Pretende retornar a Ilhéus? } \\
\hline Sim & 94,4 \\
\hline Não & 5,6 \\
\hline \multicolumn{2}{|c|}{ Recomenda a outras pessoas uma visita a cidade de llhéus? } \\
\hline Sim & 94,4 \\
\hline Não & 5,6 \\
\hline \multicolumn{2}{|c|}{ Meio de transporte utilizados para chegar em llhéus } \\
\hline Avião & 47,2 \\
\hline Automóvel & 37,6 \\
\hline Ônibus & 15,2 \\
\hline \multicolumn{2}{|c|}{ Motivo da Viagem } \\
\hline Passeio/Lazer & 81,6 \\
\hline Visita a parentes e amigos & 11,2 \\
\hline Negócios & 4,8 \\
\hline Outros & 2,4 \\
\hline \multicolumn{2}{|c|}{ Estado Civil } \\
\hline Solteiro & 21,6 \\
\hline Desquitado & 7,2 \\
\hline Viúvo & 4,0 \\
\hline Casado & 65,6 \\
\hline Outros & 1,6 \\
\hline \multicolumn{2}{|c|}{ Faixa etária (em anos) } \\
\hline abaixo de 18 & 1,6 \\
\hline de 18 a 25 & 11,2 \\
\hline de 26 a 35 & 30,4 \\
\hline de 36 a 50 & 37,6 \\
\hline de 51 a 65 & 14,4 \\
\hline acima de 65 & 4,8 \\
\hline \multicolumn{2}{|c|}{ Meios de Hospedagem utilizados durante a estadia em Ilhéus } \\
\hline Não responderam & 48,0 \\
\hline Resort & 26,4 \\
\hline Hotel 3 Estrelas & 20,8 \\
\hline Pousada & 2,4 \\
\hline Casa alugada & 1,6 \\
\hline Hotel 5 Estrelas & 0,8 \\
\hline \multicolumn{2}{|c|}{ Influência da viagem } \\
\hline Comentário parente/amigos & 30,4 \\
\hline Agência de viagens & 8,0 \\
\hline Propaganda/Publicidade & 4,0 \\
\hline Internet & 4,0 \\
\hline Livros/TV/Filmes & 5,6 \\
\hline Já conhecia o local & 42,4 \\
\hline Outros & 5,6 \\
\hline \multicolumn{2}{|c|}{ Nível de instrução } \\
\hline
\end{tabular}


ANEXO D - Perfil/características (estado civil, faixa etária, nível de instrução, nível de renda, sexo e estado de origem) do turista de ilhéus, em percentagem.

\begin{tabular}{|c|c|}
\hline Perfil/Características & $(\%)$ \\
\hline $1^{\circ} \mathrm{Grau}$ Completo & 4,8 \\
\hline $2^{\circ}$ Grau Incompleto & 3,2 \\
\hline $2^{\circ}$ Grau Completo & 17,6 \\
\hline Técnico & 10,4 \\
\hline Superior & 56,8 \\
\hline Outros & 4,8 \\
\hline \multicolumn{2}{|c|}{ Estado de origem } \\
\hline Bahia & 23,2 \\
\hline Minas Gerais & 20 \\
\hline Goiás & 3,2 \\
\hline Distrito Federal & 19,2 \\
\hline Paraná & 1,6 \\
\hline São Paulo & 16,0 \\
\hline Rio de Janeiro & 5,6 \\
\hline Pernambuco & 0,8 \\
\hline Santa Catarina & 0,8 \\
\hline Maranhão & 0,8 \\
\hline Espírito Santo & 1,6 \\
\hline Sergipe & 1,6 \\
\hline Alagoas & 0,8 \\
\hline Pará & 1,6 \\
\hline \multicolumn{2}{|c|}{ Renda (em R\$) } \\
\hline até 604 & 12 \\
\hline 605 a 755 & 2,4 \\
\hline 756 a 1359 & 13,6 \\
\hline 1360 a 1510 & 1,6 \\
\hline 1511 a 2114 & 17,6 \\
\hline 2115 a 2265 & 3,2 \\
\hline 2266 а 2869 & 13,6 \\
\hline 2870 a 3020 & 2,4 \\
\hline 3021 a 3624 & 7,2 \\
\hline 3625 а 3775 & 0,8 \\
\hline 3776 a 4379 & 4,0 \\
\hline 4380 a 4530 & 4,0 \\
\hline 45315134 & 4,8 \\
\hline a partir de 5135 & 12,8 \\
\hline
\end{tabular}

Fonte: Dados da pesquisa. 
ANEXO E - Coeficientes, valores de "t", coeficientes de determinação e estatística "F", por regressão.

\begin{tabular}{|c|c|c|c|c|}
\hline $\begin{array}{l}\text { Variáveis } \\
\text { Explicativas }\end{array}$ & $\begin{array}{c}\text { Regressão } 1 \\
y=x\end{array}$ & $\begin{array}{c}\text { Regressão } 2 \\
\ln y=x\end{array}$ & $\begin{array}{c}\text { Regressão } 3 \\
y=\ln x\end{array}$ & $\begin{array}{c}\text { Regressão } 4 \\
\ln y=\ln x\end{array}$ \\
\hline Constante & $\begin{array}{c}7,596693 \\
(13,330)\end{array}$ & $\begin{array}{c}1,887757 \\
(14,069)\end{array}$ & $\begin{array}{c}7,522759 \\
(13,052)\end{array}$ & $\begin{array}{c}1,849202 \\
(13,554)\end{array}$ \\
\hline$F_{1}$ & $\begin{array}{c}0,658704 \\
(6,405)\end{array}$ & $\begin{array}{c}0,123927 \\
(5,118)\end{array}$ & $\begin{array}{c}0,648462 \\
(6,232)\end{array}$ & $\begin{array}{c}0,123069 \\
(4,996)\end{array}$ \\
\hline$F_{2}$ & $\begin{array}{l}1,092313 \\
(10,629)\end{array}$ & $\begin{array}{c}0,224091 \\
(9,262)\end{array}$ & $\begin{array}{l}1,091061 \\
(10,533)\end{array}$ & $\begin{array}{c}0,221319 \\
(9,026)\end{array}$ \\
\hline$F_{3}$ & $\begin{array}{c}0,723826 \\
(7,141)\end{array}$ & $\begin{array}{c}0,143853 \\
(6,028)\end{array}$ & $\begin{array}{c}0,719303 \\
(7,053)\end{array}$ & $\begin{array}{c}0,142596 \\
(5,906)\end{array}$ \\
\hline$F_{4}$ & $\begin{array}{c}0,327893 \\
(3,093)\end{array}$ & $\begin{array}{c}0,050834^{*} \\
(2,036)\end{array}$ & $\begin{array}{c}0,303625 \\
(2,867)\end{array}$ & $\begin{array}{c}0,44202 \\
(1,763)\end{array}$ \\
\hline$F_{5}$ & $\begin{array}{c}0,674487 \\
(6,434)\end{array}$ & $\begin{array}{c}0,126975 \\
(5,144)\end{array}$ & $\begin{array}{c}0,668946 \\
(6,354)\end{array}$ & $\begin{array}{c}0,125449 \\
(5,034)\end{array}$ \\
\hline$F_{6}$ & $\begin{array}{c}0,405196 \\
(4,031)\end{array}$ & $\begin{array}{c}0,083352 \\
(3,521)\end{array}$ & $\begin{array}{c}0,400904 \\
(3,959)\end{array}$ & $\begin{array}{c}0,080855 \\
(3,373)\end{array}$ \\
\hline$F_{7}$ & $\begin{array}{c}0,169040^{* *} \\
(1,703)\end{array}$ & $\begin{array}{c}0,002038^{\text {NS }} \\
(0,087)\end{array}$ & $\begin{array}{c}0,149278 \text { NS } \\
(1,498)\end{array}$ & $\begin{array}{c}-0,0017466^{N S} \\
-(0,074)\end{array}$ \\
\hline$X_{1}$ & $\begin{array}{c}-0,185808^{* *} \\
(-1,739)\end{array}$ & $\begin{array}{c}-0,0334400^{N S} \\
(-1,330)\end{array}$ & $\begin{array}{c}-0,4250488^{N S} \\
-(1,173)\end{array}$ & $\begin{array}{c}-0,032725^{N S} \\
-(0,382)\end{array}$ \\
\hline$X_{2}$ & $\begin{array}{l}-0,050804^{* *} \\
-(-1,864)\end{array}$ & $\begin{array}{c}-0,100651^{* *} \\
(-1,660)\end{array}$ & $\begin{array}{c}-0,294879^{* *} \\
-(1,891)\end{array}$ & $\begin{array}{c}-0,056446 \\
-(1,529)\end{array}$ \\
\hline$X_{3}$ & $\begin{array}{c}0,000059^{\text {NS }} \\
(0,003)\end{array}$ & $\begin{array}{c}0,040303^{\text {NS }} \\
(0,770)\end{array}$ & $\begin{array}{c}-0,004834 \\
-(0,022)\end{array}$ & $\begin{array}{c}0,035613^{\text {NS }} \\
(0,673)\end{array}$ \\
\hline$X_{4}$ & $\begin{array}{c}0,058097^{\mathrm{NS}} \\
(0,733)\end{array}$ & $\begin{array}{c}0,023946 \\
(1,282)\end{array}$ & $\begin{array}{c}0,070961 \\
(0,875)\end{array}$ & $\begin{array}{c}0,023944 \\
(1,248)\end{array}$ \\
\hline$X_{5}$ & $\begin{array}{c}-0,026508^{N S} \\
-(0,314)\end{array}$ & $\begin{array}{c}0,000835^{\mathrm{NS}} \\
(0,042)\end{array}$ & $\begin{array}{c}-0,0175066^{N S} \\
-(0,200)\end{array}$ & $\begin{array}{c}-0,002273^{N S} \\
-(0,109)\end{array}$ \\
\hline$X_{6}$ & $\begin{array}{c}0,066547^{\text {NS }} \\
(1,420)\end{array}$ & $\begin{array}{c}0,011870^{\mathrm{NS}} \\
(1,075)\end{array}$ & $\begin{array}{c}0,058809^{\text {NS }} \\
(1,259)\end{array}$ & $\begin{array}{c}0,009039^{\text {NS }} \\
(0,817)\end{array}$ \\
\hline$X_{7}$ & $\begin{array}{c}-0,122918^{\mathrm{NS}} \\
-(1,401)\end{array}$ & $\begin{array}{c}-0,016190^{N S} \\
(-0,784)\end{array}$ & $\begin{array}{c}-0,118606^{\mathrm{NS}} \\
-(1,346)\end{array}$ & $\begin{array}{c}-0,015110^{N S} \\
-(0,725)\end{array}$ \\
\hline$R$ & 0,85760 & 0,80309 & 0,85600 & 0,79838 \\
\hline$R^{2}$ & 0,73548 & 0,64495 & 0,73274 & 0,63741 \\
\hline$R^{2}$ ajustado & 0,70181 & 0,59976 & 0,69873 & 0,59126 \\
\hline$F$ & 21,84597 & 14,27266 & 21,54196 & 13,81237 \\
\hline
\end{tabular}

Os valores abaixo das estimativas dos parâmetros e entre parênteses referem-se aos valores da estatística "t".

${ }^{*}$ Estatisticamente significativo a 5\%. ${ }^{* *}$ Estatisticamente significativo a $10 \% .{ }^{\text {NS }}$ Estatisticamente não significativo. Os demais são estatisticamente significativos a $1 \%$. 


\section{REFERÊNCIAS BIBLIOGRÁFICAS}

ABAZA, H. (Ed.) Workshop on environmental and natural resource accounting. IApresentado ao Committee of International Development Institutions on the Environment (CIDIE), Nairobi, 1992/ http://www.unep.org/ unep/products/eeu/ecoserie/ecos3/ecos30.htm (04/02/2002)

ABLAS, L. Efeitos do turismo no desenvolvimento regional. Turismo em Análise, v.2, n.1, p.42-52, maio 1991.

ABRAMOVAY, R. O capital social dos territórios: repensando o desenvolvimento rural. Economia Aplicada, v.4, n.2, p.379-397, 2000.

AMAZONAS, M.C. Economia ambiental neoclássica e desenvolvimento sustentável. $\quad$ http://wwwsr.unijui.tche.br/ambienteinteiro/textos.html (04/02/2002)

ANDERECK, K.; VOGT, C.A. The relationship between residents' attitudes toward tourist and tourism development options. Journal of Travel Research, v.39, p.27-36, Aug. 2000.

ARLEY, A. Ouro Preto, 1897-1973: a construção social de uma cidade histórica turística. São Paulo, 1999. 274p. Tese (Doutorado) - Faculdade de Filosofia, Letras e Ciências Humanas, Universidade de São Paulo. 
ARRAES, R.A; TELES, V.K. Infra-estrutura, capital humano e crescimento setorial: uma análise para o Brasil. Estudos econômicos, n.25, 2000. 21p. http://www.caen.ufc.br/CENER/cener025.pdf (29/03/2002)

AYRES, R.; CASTANEDA B.; CLEVELAND, C.J. et al. Natural capital, human capital, and sustainable economic growth. IApresentado ao Workshop on Assessing the Role of Human and Natural Capital in Economic Production, Boston, 1996. p.1-20/ http://www.bu.edu/cees/9702.pdf (04/02/2002)

BAHIA. Superintendência de Estudos Econômicos e Socais da Bahia. http://www.sei.ba.gov.br/ (11/11/2000)

BENI, M.C. Análise estrutural do turismo. 2.ed. São Paulo: SENAC, 1998. $426 p$.

BERNARDES, E.M. Desenvolvimento do Vale do Tietê-Paraná: um enfoque de estoques de capitais. Piracicaba, 2002. 139p. Tese (Doutorado) - Escola Superior de Agricultura "Luiz de Queiroz", Universidade de São Paulo.

BOSCHI, R.R. Descentralização, clientelismo e capital social na governança urbana: comparando Belo Horizonte e Salvador. Dados - Revista de Ciências Sociais, v.42, n.4, p.655-690, 1999.

BURMAN, G.; QUEIROZ, L. A. O turismo se volta para dentro dos municípios baianos. Bahia Análise \& Dados, v.6, n.3, p.66-72, dez. 1996.

CARVALHO, C.L. Turismo, uma arma poderosa para incrementar o crescimento. http://www.embratur.gov.br/destaque/artigo (11/11/2000)

CARVALHO, C.L. A revolução silenciosa. http://www.embratur.gov.br/ destaque/artigo $(11 / 11 / 2000)$ 
CARVALHO, C.L. Turismo no Brasil - novos rumos. http://www.embratur.gov.br/destaque/artigo (11/11/2000)

CASIMIRO FILHO, C. Valoração monetária de benefícios ambientais: o caso do turismo no litoral cearense. Piracicaba, 1998. 185p. Dissertação (Mestrado) - Escola Superior de Agricultura "Luiz de Queiroz", Universidade de São Paulo.

COELHO, M.F. Turismo e renda na economia brasileira. Turismo em Análise, v.2, n.1, p.7-12, maio 1991.

COLEMAN, J.S. Foundations of social theory. Londres: The Belknap Press of Harvard University Press, 1990. 980p.

CUNHA, L. Economia e política do turismo. Lisboa: McGraw-Hill, 1997. 350p.

EMPRESA BRASILEIRA DE TURISMO. http://www.embratur.gov.br/ $(10 / 11 / 2000)$

EMPRESA DE TURISMO DA BAHIA. http://www.bahiatursa.ba.gov.br/ $(11 / 11 / 2000)$

ENGLAND, R.W. Natural capital and the theory of economic growth. 1998. 11p. http://orbit.unh.edu/cber/abs/History/Papers/Natural.doc (04/02/2002)

FELSENSTEIN, D.; FREEMAN, D. Simulating the impacts of gambling in a tourist location: some evidence from Israel. Journal of Travel Research, v.37, n.2, p.145-155, nov. 1998.

FENECH, A.; HANSELL, R.; ISLA, A. et al. (Ed.). Natural capital: views from many perspectives. p.4-20. IApresentado ao Workshop on capital natural: views from many perspectives, Toronto, 1999/ http://www.utoronto.ca/env/em16/shortcontent.htm (05/02/2002) 
FIGUEIREDO, N.M.S. Modernização, distribuição de renda e pobreza na agricultura brasileira, 1975, 1980, 1985. Piracicaba, 1996. 248p. Tese (Doutorado) - Escola Superior de Agricultura "Luiz de Queiroz", Universidade de São Paulo.

FIGUEROA, E.B.; CALFUCURA, E.T. Depreciación del capital natural, ingreso y crecimiento sostenible: lecciones de la experiencia chilena. 28p. http://www.bcentral.cl/Estudios/DTBC/138/dtbc138.pdf. (04/02/2002)

FLORES, M.; RELLO, F. Capital social: virtudes e limitações /Apresentado à Conferencia Regional sobre Capital Social e Pobreza, Santiago do Chile, $2001 /$

FONSECA, P.C.D. Evolução da ciência econômica. In: SOUZA, N.J. (Coord.). Introdução à economia. 2.ed. São Paulo: Atlas, 1997. cap.2, p.41-66.

FRECHTLING, D.C.; GORVATH, E. Estimating the multiplier effects of tourism expenditures on a local economy through a regional input-output model. Journal of Travel Research, v.37, n.4, p.324-332, May 1999.

GASPARETTO, A. Perspectivas da região cacaueira numa economia globalizada. Especiaria: revista da UESC, v.1, n.1, p.53-70, abr. 1998.

GASPARETTO, A. Região de atuação da UESC: caracterização demográfica e sócio-econômica. Ilhéus: UESC, 1998. 81p. (Relatório da Assessoria Técnica de Planejamento)

GOMES, A.S. Diagnóstico e diretrizes para o planejamento ecoturístico da Lagoa Encantada - Ilhéus (BA). Ilhéus, 1999. 81p. Monografia (Graduação) - Universidade Estadual de Santa Cruz. 
KASHYAP, R.; BOJANIC, D. A structural analysis of value, quality, and price perceptions of business ans leisure travelers. Journal of Travel Research, v.39, p.45-51, Aug. 2000.

KOZAK, M.; RIMMINGTON, M. Tourism satisfaction with Mallorca, Spain, as an off-season holiday destination. Journal of Travel Research, v.38, p.260269, Feb. 2000.

KRAEMER, A. Introdução à economia. 2.ed. Porto Alegre: Sulina, 1983. 240p.

LAGE, B.H.G.; MILONE, P.C. Economia do turismo. 7.ed. São Paulo: Atlas, 2001. 226p.

LAZZARINI S.G.; CHADDAD F.R.; NEVES, M.F. O conceito de capital social e aplicações para desenvolvimento e estratégia sustentável. Preços Agrícolas, v.14, n.163, p.10-13, maio 2000.

LIMA, G.T. Naturalizando o capital, capitalizando a natureza: o conceito de capital natural no desenvolvimento sustentável. Campinas: UNICAMP, Instituto de Economia, jun. 1999, 21p. (Texto para discussão, 74) http://www.eco.unicamp.br/publicacoes/textos/download/texto74.pdf $(04 / 02 / 2002)$

LUZAR E.J; DIAGNE, A.; EC GAN, C. et al. Profiling the nature-based tourist: a multinomial logit aprroach. Journal of Travel Research, v.37, p.48-55, Aug. 1998.

MALHOTA, N.K. Pesquisa em marketing: uma orientação aplicada. Porto Alegre: Bookman, 2001. 401p.

MASCARENHAS, G.C.C. Viabilidade mercadológica e financeira da atividade produtora de bananas na região Ilhéus-Itabuna. Viçosa, 1996. 212p. Dissertação (M.S.) - Universidade Federal de Viçosa. 
MELÉNDEZ, A. O turismo na América Latina: situação atual e tendências. Turismo: Visão e Ação, v.2, n.5, p.71-80, out.1999/mar.2000.

MIDLEJ, R.R. Desempenho do mercado de cacau. In: SEMANA DO FAZENDEIRO, 22., Uruçuca, 1997. Agenda. Uruçuca: CEPLAC/CENEX, 1997. p.57-59.

MONASTERIO, L.M. Capital social e crescimento econômico: mecanismos. http://www.ufrgs.br/cpge/anpecsul2000/textospdf/artigo23.pdf (03/02/2002)

MOTTA, R.S. Desafios ambientais da economia brasileira. Rio de Janeiro: Instituto de Pesquisa Econômica Aplicada, ago.1997. 23p. (Texto para Discussão, 509)

MULLER, J. Measuring up to tourism's potential. Finance Week, p.16-17, Sep. 1998.

NARAYAN, D.; PRITCHETT, L. Cents and sociability: household income and social capital in rural Tanzania. Economic Development \& Cultural Change, v.47, n.4, p.871-897, 1999.

NASCIMENTO, H.M. Capital social e desenvolvimento sustentável no sertão baiano: a experiência de organização dos pequenos agricultores do município de Valente. Campinas, 2000. 190p. Dissertação (M.S.) - Instituto de Economia, Universidade Estadual de Campinas.

PEREIRA, D.J.S. Diferenças de escolaridade e rendimento do trabalho nas regiões nordeste e sudeste do Brasil. Piracicaba, 2001. 98p. Dissertação (Mestrado) - Escola Superior de Agricultura "Luiz de Queiroz", Universidade de São Paulo.

PERES, F.C. Capital social: a nova estrela do crescimento econômico. Preços Agrícolas, v.14, n.163, p.6-9, maio 2000. 
PERRY, G. Dos recursos naturais à economia do conhecimento. 2001. 12p. http://wbln0018.worldbank.org/LAC/lacinfoclient.nsf/ (14/04/2002)

PINHO, D.B. Evolução da ciência econômica. In: PINHO, D.B.; VASCONCELLOS, M. A. S. (Org.). Manual de Economia. 2.ed. São Paulo: Saraiva, 1996. cap.2, p.31-59.

PRUGH, T. Natural capital and human economic survival. Solomons: ISEE Press, 1995. 189p.

PUTNAM, R.D. Comunidade e democracia: a experiência da Itália moderna. Rio de Janeiro: Fundação Getúlio Vargas, 1996. 257p.

QUEIROZ, L.M.A. Turismo: uma nova atividade econômica na região do cacau. Salvador, 1993. 120p. Dissertação (M.S.) - Escola de Administração, Universidade Federal da Bahia.

QUEIROZ, L. Ilhéus: o polo turístico da região do cacau. Bahia Análise \& Dados, v.2, n.4, p.27-31, mar.1993.

RABAHY, W.A. Planejamento do turismo: estudos econômicos e fundamentos econométricos. São Paulo: Loyola, 1990. 167p.

ROSSETTI, J.P. Introdução à economia. São Paulo: Atlas, 1997. 922p.

SABBAG, W.J. Modernização agrícola em Pernambuco. Piracicaba, 2000. 165p. Tese (Doutorado) - Escola Superior de Agricultura "Luiz de Queiroz", Universidade de São Paulo.

SACHS, I.; LAGES, V.N. Capital social e desenvolvimento: novidade para quem? /Apresentado a conferencia regional sobre capital social e pobreza, Santiago, Chile, 2001/ 
SANTOS, A. B. Evolução diferenciada entre os estados brasileiros do cultivo e do processamento industrial da soja - período de 1970 a 1999. Piracicaba, 2000. 84p. Dissertação (M.S.) - Escola Superior de Agricultura "Luiz de Queiroz", Universidade de São Paulo.

SANTOS, M. C. Análise das dificuldades encontradas pelos agentes receptivos de turismo do município de llhéus. Ilhéus, 1999. 70p. Monografia (Graduação) - Universidade Estadual de Santa Cruz.

SCHROEDER, T. The relationship of residents' image of their state as a tourist destination and their support for tourism. Journal of Travel Research, p.7173, Spring 1996.

SCHULTZ, T. W. O capital humano: investimentos em educação e pesquisa. Rio de Janeiro: Zahar Editores, 1973. 236p.

SEJÁK, J. The natural capital of central and eastern European countries: the role and valuation of natural assets in central and eastern Europe. http://www.rec.org/REC/Publications/PaperSeries/Paper2/cover.html $(04 / 02 / 2002)$

SELIGSON, M.A.; RENNO, L.R. Mensurando confianca interpessoal: notas acerca de um conceito multidimensional. Dados - Revista de Ciências Sociais, v.43, n.4, p.783-803, 2000.

SHARMA, S. Applied multivariate techniques. New York: John Wiley \& Sons, 1996. 493p.

SHIKIDA, P.F.A. A evolução diferenciada da agroindústria canavieira no Brasil de 1975 a 1995. Piracicaba, 1997. 191p. Tese (Doutorado) - Escola Superior de Agricultura "Luiz de Queiroz", Universidade de São Paulo. 
SILVA FILHO, G.E. As novas estratégias de desenvolvimento econômico regional. Revista Econômica do Nordeste, v.30, n.2, p.212-233, abr./jun.1999.

SILVA, J.A.S. O turismo e seus mitos. Bahia Análise \& Dados, v.1, n.3, p.7881, dez.1991.

SILVA, M.S. Cooperativismo agropecuário nordestino: diagnóstico e tipologia. Piracicaba, 2000. 227p. Dissertação (M.S.) - Escola Superior de Agricultura "Luiz de Queiroz", Universidade de São Paulo.

SOUBBOTINA, T.P.; SHERAM, K. Beyond economic growth: meeting the challenges of global development. 2000. 160p. http://www.worldbank.org/depweb/beyond/beyondsp/chapter1.htm $(05 / 02 / 2002)$

SOUZA, A.Q. O turismo em llhéus na baixa estação. Ilhéus, 1997. 34p. Monografia (Graduação) - Universidade Estadual de Santa Cruz.

SOUZA, N.J. Desenvolvimento econômico. 3.ed. São Paulo: Atlas, 1997. $415 p$.

TEIXEIRA, M.S.G. Investimento no turismo do Ceará: uma análise dos impactos sobre o produto, renda, emprego. São Paulo, 1996. 185p. Tese (Doutorado) - Escola de Comunicação e Artes, Universidade de São Paulo.

TEIXEIRA, M.S.G.; CASTELLAR, J.; SOARES, F.A. et al. Análise dos impactos de projetos selecionados e de gasto turístico sobre produto, renda e emprego no Estado do Ceará. Revista Econômica do Nordeste, v.29, n. esp., p.681-693, jul.1998. 
TOMASI, D.L. Sistema de avaliação e acompanhamento turístico dos municípios engajados no PNMT, através de indicadores sociais, econômicos, infra-estruturais e ambientais. Turismo: Visão e Ação, v.2, n.5, p.55-70, out.1999/mar.2000.

TOOMAN, L.A. Tourism and development. Journal of Travel Research, v.35, n.3, p.33-40, Winter 1997.

TORRAS, M. Sustainability or natural capital disinvestment? A restrospective on Brazilian economic growth, 1965-1993. Estudos Econômicos, v.30, n.3, p.351-375, jul./set.2000.

TORRES, I. Turismo e emprego na economia brasileira. Turismo em Análise, v.2, n.1, p.13-18, maio 1991.

TROSTER, R.L.; MOCHÓN, F. Introdução à economia. São Paulo: Makron Books, 1999. 401p.

VERSCHOORE FILHO, J.R.S. Metade sul: uma analise das politicas publicas para o desenvolvimento regional no Rio Grande do Sul. Porto Alegre, 2000. 210p. Dissertação (M.S.) - Escola de Administração, Universidade Federal do Rio Grande do Sul.

WITT, S.F.; MOUTINHO, L. (Ed.). Tourism: marketing and management handbook. Cambridge: Prentice Hall International, 1989. 656p.

WOOLCOCK, M. The place of social capital in understanding social and economic outcomes. IApresentado ao Symposium on the Contribution of human and social capital to sustainable economic growth and well-being, Chateau Frontenac, Quebec City, 2000/ http://www1.oecd.org/ els/pdfs/EDSCERIDOCA008.pdf/ (01/02/2002) 
ZUMBADO, C. Desarrollo y capital social: redescubriendo la riqueza de las naciones. Instituciones y Desarrollo, p.175-189, Oct.1998. http://www.iigov.org/revista/rc01/pdf/IIG1-com1.pdf (03/02/2002) 